\title{
The Impact of Corporate Social Responsibility on Investment Recommendations: Analysts' Perceptions and Shifting Institutional Logics
}

\section{Citation}

loannou, loannis, and George Serafeim. "The Impact of Corporate Social Responsibility on Investment Recommendations: Analysts' Perceptions and Shifting Institutional Logics." Strategic Management Journal (forthcoming).

\section{Published Version}

10.1002/smj.2268

\section{Permanent link}

http://nrs.harvard.edu/urn-3:HUL.InstRepos:12534952

\section{Terms of Use}

This article was downloaded from Harvard University's DASH repository, and is made available under the terms and conditions applicable to Open Access Policy Articles, as set forth at http:// nrs.harvard.edu/urn-3:HUL.InstRepos:dash.current.terms-of-use\#OAP

\section{Share Your Story}

The Harvard community has made this article openly available.

Please share how this access benefits you. Submit a story.

\section{Accessibility}




\title{
The Impact of Corporate Social Responsibility on Investment Recommendations:
}

\author{
Analysts' Perceptions and Shifting Institutional Logics
}

\author{
Ioannis Ioannou and George Serafeim*
}

\begin{abstract}
We explore the impact of corporate social responsibility (CSR) ratings on sell-side analysts' assessments of firms' future financial performance. We suggest that when analysts perceive CSR as an agency cost, due to the prevalence of an agency logic, they produce pessimistic recommendations for firms with high CSR ratings. Moreover, we theorize that over time, the emergence of a stakeholder focus, and the gradual weakening of the agency logic, shifts the analysts' perceptions of CSR ratings and results in increasingly less pessimistic recommendations for firms with high CSR ratings. Using a large sample of publicly traded US firms over 15 years, we confirm that in the early 1990s, analysts issue more pessimistic recommendations for firms with high CSR ratings. However, in more recent years analysts progressively assess these firms less pessimistically, and eventually they assess them optimistically. Furthermore, we find that more experienced analysts and analysts at higher-status brokerage houses are the first to shift the relation between CSR ratings and investment recommendation optimism. We find no significant link between firms' CSR ratings and analysts' forecast errors, indicating that learning is unlikely to account for the observed shifts in recommendations.
\end{abstract}

\footnotetext{
${ }^{*}$ Ioannis Ioannou is an Assistant Professor at London Business School. George Serafeim is an Assistant Professor at Harvard Business School. We are grateful to Joshua Margolis, Constantinos Markides, Markus Reitzig, Rodolphe Durand, Olga Hawn, seminar participants at the research brown bag (SE area) of the London Business School, the academic conference on Social Responsibility at University of Washington - Tacoma, the 2010 European Academy of Management Conference anonymous referees and participants, the 2010 Academy of Management Conference anonymous referees and participants and the 2010 Strategic Management Society meeting anonymous referees and participants. Ioannou acknowledges financial support from the Research and Materials Development Fund (RAMD) at the London Business School. Serafeim acknowledges financial support from the Division of Faculty and Research Development at the Harvard Business School All remaining errors are our own.
} 


\section{INTRODUCTION}

In recent years, a growing number of companies are adopting various corporate social responsibility (CSR) initiatives - the voluntary incorporation of social and environmental issues into a company's business model and operations (European Commission 2001) - in an attempt to meet the needs and expectations of a range of stakeholders, including but not confined to the company's shareholders. Meanwhile, numerous information intermediaries have been established to gather and make publicly available information about these CSR initiatives - what is termed as "CSR ratings" or "CSR scores" - thus rating and ranking corporations across several dimensions of environmental, social, and corporate governance performance. Not only information intermediaries, but also a number of voluntary reporting standards have emerged to enable these information intermediaries to standardize the way they disclose their CSR ratings. Therefore, CSR scores have increasingly become more credible but also more easily comparable across industries and geographies. The adoption and implementation of CSR policies as well as the availability of CSR scores, has in fact generated a growing interest by financial markets, and investment analysts in particular (Eccles, Krzus \& Serafeim 2011). Accordingly, given the pivotal role that financial markets play in the allocation of scarce capital resources and in the derivation of a company's market value, understanding whether and in what ways these markets assess a firm's CSR scores is critical. In this article, and in order to explore this issue, we follow extensive prior research in adopting a sociological approach towards the processes and mechanisms associated with the assessment of corporate policies by financial markets (Zuckerman, 1999; Cetina \& Bruegger, 2002; MacKenzie, 2003; Zajac \& Westphal, 2004; Lok, 2010).

Specifically, we adopt a social constructionist view of financial markets and explore how the weakening of the prevalent agency logic, due to the emergence of a stakeholder orientation, is associated with a shift in the way analysts respond to CSR ratings over a 15-year time horizon. Our theory derives from a neo-institutional perspective which argues that organizational policies achieve legitimacy to the extent that they are consistent with prevailing institutional logics or 'historically-variant sets of assumptions, beliefs, values, and rules by which individuals ... interpret organizational reality and what 
constitutes appropriate behavior' (Thornton \& Ocasio (1999): p.805; see also Zajac \& Westphal (2004): p.433). We posit that within an institutional context whereby CSR initiatives are perceived as serving managerial objectives (i.e. an agency cost) rather than serving shareholders' interests (Atkinson \& Galaskiewicz, 1988; Galaskiewicz, 1997), analysts' reactions in the form of investment recommendations will be more pessimistic the higher the CSR scores of the focal company are. Subsequently, we argue for a gradual weakening of this agency-based institutional logic through the emergence of a stakeholder orientation. Within this emerging perspective, CSR increasingly becomes more legitimate in the eyes of both shareholders and analysts, and is consequently perceived as a set of activities that companies should undertake as insurance-like protection for the relationship-based intangible assets (Godfrey, 2005) or even as activities that may positively contribute towards profitability (Margolis, Elfenbein, \& Walsh, 2007). Therefore, we posit that in later time periods, companies with higher CSR scores will be associated with increasingly less pessimistic analysts' recommendations, and eventually, they may even be associated with optimistic recommendations.

Relatedly, prior articles have explored how a shift in the prevalent institutional logic may lead to changes in the interpretation of a particular corporate policy. For example, Zajac et al. (2004) show that the market's reaction to stock repurchase plans changes as the prevalent logic shifts: while under a "corporate logic" the market reacts positively to stock repurchase plans, under an agency logic it reacts negatively towards the very same plans. Similarly, a series of articles by Thornton and co-authors focused on the publishing industry show that a shift from an "editorial" logic to a "market" logic results in changes in executive succession, organizational structure and even acquisition targets (Thornton \& Ocasio, 1999; Thornton, 2001, 2002). Importantly, scholars have also explored the reactions and evaluations of market intermediaries, observers and external third parties when companies adopt strategies consistent with or even in contrast to the prevailing or shifting institutional logic (e.g. Polos, Hannan, \& Carroll, 2002; Hannan, Polos, \& Carroll, 2004; Durand, Rao, \& Monin, 2007; Philippe \& Durand, 2011). 
In this article, we theoretically argue and empirically test for the link between the weakening of the agency logic through the emergence of a stakeholder orientation, and investment analysts' recommendations for firms with high CSR scores, using a large sample of publicly traded US firms for the period 1993 to 2007. Specifically, using consensus (mean) analyst recommendation in the focal firm-year as the dependent variable, and a composite CSR strengths score constructed with data from Kinder, Lyndenberg and Domini (KLD) as the independent variable of interest, we find that in the early 1990s, analysts issue more pessimistic recommendations for firms with high CSR scores. Over time and leading to 2007, analysts issue increasingly less pessimistic and eventually, optimistic recommendations for firms with higher CSR scores. In addition, we argue that more experienced analysts as well as higher-status brokerage houses are more likely to be the first to shift their reactions towards less pessimistic (more optimistic) recommendations for such firms. We therefore develop and provide evidence for a more nuanced understanding of the sociological processes associated with the perceptions and assessments of firms with high CSR scores by analysts during times of change in the prevailing institutional logic.

With our work we make some other key contributions. First, we contribute to the literature that explores the sociological mechanisms through which corporate policies are perceived and interpreted by the financial markets (Zuckerman, 1999; Zajac \& Westphal, 2004); more specifically, we contribute to the sub-stream of literature that explores the role of intermediaries during periods when the prevailing logic shifts (Polos et al., 2002; Hannan et al., 2004; Durand et al., 2007; Philippe \& Durand, 2011). Second, to the best of our knowledge, this article is the first to explore both theoretically and empirically, the role of investment analysts and the processes that affect their reactions in the context of CSR ratings. Importantly, it is the first one to empirically document the emergence of a new logic (i.e. a stakeholder orientation) that appears to be weakening the dominant logic (i.e. agency) of the last forty or so years in financial markets. We also contribute to the literature stream within CSR that seeks to understand the link between CSR and the derivation of firm value in financial markets (e.g. Lee \& Faff, 2009; El Ghoul, Guedhami, Kwok et al., 2011; Goss \& Roberts, 2011; Cheng, Ioannou, \& Serafeim, 2014). Third, our article is linked to the recent 
literature in strategy that explores analysts' reactions as firms respond to radical technological change as well as how these reactions affect firms' subsequent responses (Benner, 2007, 2010; Benner \& Ranganathan, 2012). To the extent that analysts' reactions may develop into institutional pressures, the evidence we provide here hints towards the pressure that financial markets will be exerting on companies to adopt more CSR policies in the future. Whereas most of the prior work on social construction of capital markets has focused on issues of governance (e.g. stock repurchase plans, or incentives provision), our work broadens the theoretical scope of social construction theory to argue that in addition to corporate governance issues, social construction may intrinsically affect the perception and evaluation by analysts of social and environmental initiatives that companies implement. Similarly, whereas the strategy literature to date has explored analysts' reactions to predominantly financial metrics or radical technological innovations, our article broadens the scope of this literature as well, by exploring the impact of non-financial metrics on investment recommendations. Finally, since CSR is generally regarded as a set of policies adopted by corporations to meet the demands and expectations of multiple stakeholders, our article explores how a shifting logic affects the perception and evaluation of such firm policies by a key stakeholder and social actor in the capital markets, namely sell-side analysts.

\section{THEORY AND HYPOTHESES}

\section{From Agency to Stakeholder Logics of CSR}

Numerous articles have documented the emergence and institutionalization of the agency logic of corporate control according to which a corporation is regarded as merely a nexus of contractual arrangements between individuals (Jensen \& Meckling, 1976; Williamson \& Winter, 1993; Zajac \& Westphal, 2004). Thus, managers are assumed to be fungible agents of shareholders who are likely to pursue corporate actions that advance their own personal interests at the expense of shareholder value (e.g. Fama \& Jensen, 1983b, 1983a; Useem, 1993; Davis \& Thompson, 1994; Westphal \& Zajac, 1995; Useem, 1996; Zajac \& Westphal, 2004). According to Zajac \& Westphal (2004) and other scholars, such strong agency assumptions resulted in the

surfacing of a different model of economic resource allocation termed as "investor capitalism." Assuming 
that a firm is simply a set of contracts and that managerial action results in significant agency costs, the "investor capitalism" model postulates that the capital allocation process is better left to investors rather than managers (p. 436). Thus, contrary to existing dominant beliefs under a "corporate" logic, managers and executives were no longer regarded as "professionals with unique strategic knowledge that is required for efficient allocation of corporate resources" (Zajac \& Westphal, 2004: 436). As expected, a number of corporate policies were viewed and interpreted through the lens of this agency logic. For example, Zajac \& Westphal (1995) show that in the mid-to-late 1980s, executive incentive plans were justified as a mechanism to align managerial and shareholder interests rather than a mechanism to attract and retain scarce executive talent. Moreover, Zajac \& Westphal (2004) show that due to the switch to the agency logic, stock market reactions to repurchase plan adoptions shifted from negative to positive over time.

In the accounting and finance literature numerous articles provide evidence that investment analysts' expectations of a focal company's future growth and performance are in fact a good proxy for the expectations of the company's own shareholders (Fried \& Givoly, 1982; O’Brien, 1988; Abarbanell, Lanen, \& Verrecchia, 1995). More generally, these sell-side analysts are employed by brokerage houses and research firms, they track the performance of a specific set of firms over time, and they generate and publish two main products: forecasts of future earnings as well as investment recommendations that clients buy, sell, or hold their shares in the stocks of these firms. The same literature provides ample evidence that market participants extensively use these products, and documents their significant influence over stock prices and trading volumes (Stickel, 1995; Womack, 1996; Francis \& Soffer, 1997; Barber, Lehavy, McNichols et al., 2001). From a sociological perspective, Zuckerman (1999) notes that "analysts serve as "surrogate investors" (cf. Hirsch (1972)) in that their recommendations and forecasts significantly affect investor appetite for a firm's shares. Indeed, while analysts often disagree amongst themselves on a firm's 
prospects (Kandel \& Pearson, 1995), certain currents of opinion, especially when voiced by prominent analysts, significantly influence prices."1 (p.1408)

Starting in the early 1990s, investment analysts started to witness the growing interest of companies in adopting CSR programs, and began to explore publicly available CSR ratings and rankings provided by third parties. For example, Paine (2003) reports the results from two early surveys of investors regarding the broader domain of CSR and ethics: in the first one, a survey of US investors in 1993, $72 \%$ claimed to consider a company's ethics when deciding whether to invest in its stock. ${ }^{2}$ Importantly, a second survey conducted in 1994 found that $26 \%$ of investors said that a company's business practices and ethics were extremely important to their investment decisions. ${ }^{3}$ Paine (2003) then concludes that "whether or not investors themselves [were] are directly concerned about corporate conduct, they recognize[d] that others' concerns can translate into financial consequences for the companies they invest in".

However, early interpretations of CSR within the investor community appear to have been heavily based on arguments that served as precursors to the subsequent formalization of agency theory: noticeably, Nobel laureate Milton Friedman famously contended in 1970 in the New York Times Magazine that "the social responsibility of the firm is to increase its profits" (Friedman, 1970) and even earlier, in his seminal 1962 book, he stated that "few trends could so thoroughly undermine the very foundations of our free society as the acceptance by corporate officials of a social responsibility other than to make as much money for their stockholders as possible"(p.133) (Friedman, 1962). In fact, Freeman et al. (2010) note: "Milton

${ }^{1}$ Relatedly Cohen et al. (2010) note "that sell-side analysts have an incentive to produce unbiased forecasts and recommendations for investors only if they are compensated for such behavior. Due to a lack of data on direct compensation, the literature generally tests this idea by linking analyst behavior to measures of implicit incentives or career concerns. Stickel (1992) finds that highly rated "All-American" analysts (who are typically better compensated than other analysts) are more accurate earnings forecasters than other analysts, suggesting that accuracy is rewarded. Similarly, Mikhail, Walther, and Willis (1999) document that poor relative performance leads to job turnover."

${ }^{2}$ According to Paine (2003), Corporate Ethics in America is a research study commissioned by the Society of Consumer Affairs Professionals in Business Foundation and conducted by the Gallup Organization (Arlington, VA.: SOCAP Foundation, 1993), pp.15-16

${ }^{3}$ Results of the survey conducted by the Council on Foundations and Walker Information in 1994 and are noted in Walker Information, Measurements, vol. 7, no. 4 (Indianapolis, Ind.: Walker Information, 1998), p.2. 
Friedman's writings on social responsibility and the purpose of the firm have become canonical. Indeed, much of the writing within finance, economics, and management for the past twenty-five years assumes not only that his views - about why firms exist and to whom manages have obligations - are correct, but also that existing US law is built upon them (Donaldson \& Preston, 1995; Marens \& Wicks, 1999)" (p.202). Although such socially legitimate critiques of CSR-type policies predated the formal introduction and institutionalization of agency theory, it is apparent that to a considerable extent, they may well be viewed as precursors to agency theory itself. Indeed, as Lee (2008) notes, opponents of CSR during the 1960s and 1970s argued for segregated roles of economic and political actors and therefore, they advocated that social problems should be left to politicians and civil society to deal with (p. 56). Thus, they perceived economic and social goals to be separate and typically in conflict. ${ }^{4}$ In a similar spirit, later studies by Dewatripont, Jewitt \& Tirole (1999) argued that CSR may weaken managerial accountability and Atkinson \& Galaskiewicz (1988) focused on one aspect of CSR - namely, charitable giving - and showed that firms with high levels of CEO ownership give less generously to charities than firms with low levels of CEO ownership. They interpret this finding as evidence of better alignment between CEO and shareholder incentives when CEO ownership is higher. ${ }^{5}$

Influenced by the overarching agency logic, analysts and investors interpreted CSR as meeting the expectations of non-shareholding stakeholders, and in the process destroying shareholder wealth (i.e. they perceived CSR merely as a transfer payment). This is not to imply of course, that advocates of CSR did not exist during this time (see for example early works by (Andrews, 1971; Steiner, 1971; Davis, 1973; Sethi,

\footnotetext{
${ }^{4}$ We note that such views already contained important commonalities with the agency logic, even though they also contained some differences. For example, the business community regarded social responsibility as bad for business in the 1960s and early 1970s, yet this is a view that does not necessarily require that managers are self-maximizing at the expense the shareholders (as the formalized agency theory would predict). We thank an anonymous reviewer for pointing this out to us.

${ }^{5}$ Overall though, empirical work at the time found mixed results regarding the existence of agency costs. For example, (Navarro, 1988) finds that charitable contributions can be profit maximizing if they act as a kind of advertising expense or a quasi-fringe benefit for employees. Also, in a follow-up article, (Galaskiewicz, 1997) finds mixed support for agency theory; a large outside shareholder has no impact on contributions. If agency costs were present, a large outside shareholder would exercise more control over management and therefore lower charitable contributions.
} 
1975; Carroll, 1979). Nonetheless, the institutionalization of the agency logic as documented in the literature, not only gave stronger social legitimacy to prior arguments against CSR-type policies but also, it appears to have dominated analysts' and investors' perceptions and interpretations of both CSR as well as several other corporate policies (Useem, 1993; Davis \& Thompson, 1994; Westphal \& Zajac, 1994; Useem, 1996; Zajac \& Westphal, 2004). Against this background, we posit that in the early 1990s under the prevalence of the agency logic, the perceptions of the investment community for firms that undertook CSR were predominantly unfavorable, and therefore we predict that sell-side analysts' recommendations were more pessimistic towards firms with higher CSR scores.

Moreover, we argue that the subsequent gradual emergence and institutionalization of what has been termed as the "Business Case for CSR" (Margolis et al., 2007) and the collective realization that CSR may be an insurance-like protection for the relationship-based intangible assets of a company (Godfrey, 2005) or a risk-mitigation strategy, have weakened the agency logic by bringing to the forefront a wider stakeholder focus. Therefore, we suggest that after the early 1990s, analysts' perceptions and interpretations of CSR will be affected by this shift in logics and hence, their recommendations will become less unfavorable, and may even become favorable towards firms with high CSR ratings. Next, we present several compelling reasons for why the interpretation of CSR through an agency logic is gradually weakened by the emergence of a stakeholder orientation.

First, in many countries around the world, and especially in Europe, the socially responsible investing (SRI) movement has been gaining significant momentum within the analyst and investor communities, and it increasingly constitutes a non-negligible part of the global financial market. While developing into its modern form, the SRI shifted away from an emphasis on ethics and towards the incorporation of environmental, social and governance factors (i.e. CSR ratings) into investment decisions. This type of integration became an investment strategy aimed at improving the risk-return profile of the SRI portfolios but also, one that explicitly seeks to outperform the market rather than simply articulate an 
ethical stance on behalf of its investors (Sparkes \& Cowton, 2004). Paine (2003) estimates that if one accounts for assets in all socially screened portfolios "the sector grew at a compound annualized rate of $74 \%$ between 1995 and 1999 , compared to a rate of $25 \%$ for all mutual fund assets" to reach a total of $\$ 1.5$ trillion under management by 1999 (compared to $\$ 16.3$ trillion of total assets under management). She also notes that throughout the 1990s, a number of mainstream brokerage firms launched funds and other products to appeal to this sector, including Merrill Lunch, Smith Barney, Vanguard, UBS and Credit Suisse. It is estimated that by 2015 , global SRI will reach $\$ 26.5$ trillion assets under management, representing over $15 \%$ of the global total (Booz \& Company 2012).

Reflecting the increasing penetration and institutionalization of the SRI wave in the analyst and investor community, in 2003 the UNEP Finance Initiative (UNEP FI) found that "agreement [among analysts] that environmental, social and corporate governance issues affect long-term shareholder value... [and] in some cases those effects may be profound". Two years later, in 2006, the UN launched the Principles for Responsible Investing (UN PRI) mainstreaming SRI and coined the definition of "Responsible Investors" as those investors who incorporate environmental, social and governance factors into their investment process. ${ }^{7}$ Relatedly, Sparkes, and Cowton (2004) perform a comprehensive review of the SRI literature and conclude that SRI "has become an investment philosophy adopted by a growing proportion of large investment institutions" and that "this shift in SRI from margin to mainstream and the position in which institutional investors find themselves is leading to a new form of SRI shareholder pressure" (p.45, emphasis added). By the mid-2000s, even the language within the analyst and investor

\footnotetext{
${ }^{6}$ Indicatively, we note that by 2007, mutual funds that integrated CSR ratings in their capital allocation decisions had assets under management of more than $\$ 2.5$ and $\$ 2$ trillion dollars in the United States and Europe respectively. Similarly, socially conscious funds in Canada, Japan and Australia held \$500, \$100 and \$64 billion, respectively. In the last ten years, assets under management of socially responsible investors grew considerably: funds in the United States, United Kingdom and Canada grew by $\$ 400$, $\$ 600$, and $\$ 400$ billion respectively, between 2001 and 2007. We calculated these numbers from information provided by national and international organizations that track socially conscious funds, such as Eurosif, Social Investment Forum, Responsible Investment Association Australasia, Social Responsible Organization, and SRI funds in Asia.

${ }^{7}$ By April 2012, the UN PRI Global Network included more than 1,000 signatories with assets under management of approximately $\$ 35$ trillion. United Nations Principles for Responsible Investment, Annual Report 2012, (http://www.unpri.org/viewer/?file=wpcontent/uploads/Annualreport20121.pdf)
} 
community began to shift: environmental, social and governance issues were now being jointly labeled as "corporate sustainability", rather than merely issues of CSR. This new terminology drew attention to the fact that in addition to perpetual profitability (i.e. sustainable shareholder returns), corporations had to be sustainable, and indeed thrive within their broader social and environmental context.

Another important milestone in the US was the establishment of a pressure group under the name of "Ceres", as early as 1989 , by a group of North American investors whose goal was to leverage the collective power of its investors to encourage both companies as well as capital markets to incorporate environmental issues into their day-to-day decision-making. By now, Ceres represents one of the world's strongest investment groups with over 60 institutional investors managing over $\$ 4$ trillion in assets. Meanwhile, sustainability indices that emerged at stock exchanges around the world also captured the attention of analysts and investors and reflected the further institutionalization of CSR. In 1999 for example, the Dow Jones Sustainability Index was formed to evaluate the sustainability performance of the largest 2,500 companies listed on the Dow Jones Global Total Stock Market Index. Several other indices followed suit amongst which the most prominent were the FTSE4GOOD index, Ethibel, Domini 400 Social Index, Vanguard Calvert Social Index Fund and the Corporate Governance Quotient (CGQ). Such developments reflected and even reinforced the weakening of the prevalent agency logic, since CSR was much less likely to be interpreted by the analyst community as an agency cost but rather, CSR was seen as a means through which to address stakeholder needs and expectations.

Several key innovations in the governance and disclosure process of companies also reinforced a broader stakeholder focus: the number of environmental and social issues that were the subject of shareholder resolutions in the US increased significantly (Glac, 2010; Carroll, Lipartito, Post et al., 2012) and these resolutions were increasingly becoming more successful (Mathiasen, Mell, \& Gallimore, 2012). Paine (2003) notes that by the year 2000, 242 out of a total 820 proposals submitted as part of the proxy process in the US, were directly related to issues of the "environment, equal employment, and international labor and human rights issues". From 2008 through the first half of 2010, more than 200 institutional 
investors and money managers, collectively controlling a total of at least $\$ 1.5$ trillion in assets, filed or cofiled shareholder resolutions on environmental, social and governance issues. Moreover, a new C-level executive position was established at many companies around the world (e.g. AT\&T, Blackstone, BT, Dow Chemical, Nestle, SAP, Siemens, Unilever, among many others) to oversee sustainability-related issues. Thus, CSR was no longer a peripheral issue (e.g. philanthropy) but rather, it increasingly became a core strategic issue and a potential driver of innovation and long-term performance (Lubin \& Esty, 2010; Kiron, Kruschwitz, Haanaes et al., 2012). At the same time, the exponential growth of sustainability reporting as well as its current transition to integrated reporting reflected the critical need to communicate such issues to the analysts and markets. ${ }^{8}$

In sum, the above trends jointly point at an emerging shift in institutional logics within the analyst community and the financial markets towards a stakeholder orientation and therefore, a re-interpretation of CSR as a legitimate part of corporate strategy, minimizing operational risks and even contributing positively towards long-term financial performance. Concurrently, stakeholder theory (Freeman, 1984; Freeman, Harrison, \& Wicks, 2007; Freeman et al., 2010) highlighted how critical it is for managers to integrate in their decision-making process the interests and expectations of a broad and diverse set of stakeholders, rather than to focus exclusively on the corporation's shareholders as previously supported by the agency logic. In fact, prior studies argue that ties with key stakeholders may mitigate the likelihood of negative regulatory, legislative or fiscal action (Freeman, 1984; Berman, Wicks, Kotha et al., 1999; Hillman \& Keim, 2001), attract socially conscious consumers (Hillman \& Keim, 2001), attract financial resources from socially responsive investors (Kapstein, 2001), enhance access to finance (Ioannou \& Serafeim, 2013) or help poorly performing firms to recover from disadvantageous positions more quickly (Choi \& Wang, 2009). In addition, stakeholder theory argues that CSR may lead to better performance by protecting and enhancing corporate reputation (Fombrun \& Shanley, 1990; Fombrun, 2005; Freeman et al., 2007).

\footnotetext{
${ }^{8}$ For example, while only 26 firms issued a sustainability report in 1992, this number grew to 5,162 by 2010 (Eccles et al., 2011). Concurrently, national governments and stock exchanges have promoted sustainability reporting by adopting laws and regulations that specifically mandate this form of disclosure (Ioannou \& Serafeim, 2012).
} 
Empirically, numerous academic articles to date have sought to uncover the link between CSR and financial performance (e.g. McWilliams \& Siegel, 2000; Rowley \& Berman, 2000; Hillman \& Keim, 2001; Margolis \& Walsh, 2003; Orlitzky, Schmidt, \& Rynes, 2003; Barnett \& Salomon, 2006) albeit, without directly exploring the perception of CSR by investment analysts. A comprehensive meta-analysis of this stream of work by Margolis et al. (2007) finds a small positive yet significant impact of CSR on profitability. The most recent article by Eccles et al. (2013) uses a matched sample methodology and finds that sustainable organizations - defined as those organizations that voluntarily integrate social and environmental issues into their strategy and business models - outperform their lower sustainability peers over an 18 year horizon, both in stock market as well as operational performance.

Similarly, a long stream of literature explores the link between environmental performance specifically, and financial performance (e.g. Russo \& Fouts, 1997; King \& Lenox, 2001; King \& Lenox, 2002) while several literature reviews (Sharma \& Starik, 2002; Etzion, 2007; Ambec \& Lanoie, 2008; Dixon-Fowler, Slater, Johnson et al., 2013) support the general finding of a positive relationship between environmental and financial performance. In particular, the main arguments in these studies are that positive environmental performance may represent a focus on innovation and operational efficiency (e.g. Porter \& Van der Linde, 1995), reflect superior organizational or management capabilities (e.g. Aragón-Correa, 1998), enhance a company's legitimacy (e.g. Hart, 1995), and may empower the firm to meet the needs of diverse stakeholders (e.g. Edward Freeman \& Evan, 1991). Consequently, these academic findings jointly provide solid justification and perhaps additional legitimization within the investment community for interpreting and assessing corporate engagement with CSR through a stakeholder lens. Summarizing all of the above discussion then, we formulate the following hypothesis:

Hypothesis 1: Over time, sell-side analysts' recommendations will be less pessimistic for firms with high CSR scores.

Although this trend may be traced, on average, across all analysts, it is also worth exploring how heterogeneity within the analyst community itself, in conjunction with the weakening of the agency logic, 
is associated with a potential shift in their investment recommendations over time. Exploring this heterogeneity also provides a more nuanced understanding of the underlying sociological processes that affect the derivation of firm value in financial markets during times of change in the overarching logic. On the one hand, if one adheres to a strict version of the efficient market hypothesis, none of the analyst attributes should matter: the potential advantages of any capital market participant are immediately eliminated through the exploitation of arbitrage opportunities (for an overview see Sheffrin (1996)). Fama (1965) for example, argues that analyst forecasts and recommendations are inconsequential for investors and therefore, analysts should disappear, if the theory is right.

In this article on the other hand, we concur with existing literature arguing that there is at least a "loose, socially mediated link" (Podolny, 1993) between an analyst's experience and status and the quality of her investment recommendations, similar to what has been suggested in other settings (e.g. Posner (1990) on judges; (Schwartz, 1987; Fine, 1996) on politicians; (Lang \& Lang, 1988; Kapsis, 1989) on artists; Phillips \& Zuckerman (2001) on analysts). In particular, prior work (Stickel, 1992; Sinha, Brown, \& Das, 1997; Clement, 1999) has documented systematic and time-persistent differences in analysts' earnings forecast accuracy, and some articles have explained why this occurs by linking analyst performance to observable analyst heterogeneity. Indicatively, Clement (1999) finds that a focal analyst's forecast accuracy is "positively associated with general and firm-specific forecasting experience and employer size, and negatively associated with the number of firms and industries followed by the analyst" (p.287).

Following this line of work, we regard analyst experience as a key variable for understanding the heterogeneity across the analyst population in terms of their perceptions and associated investment recommendations. Focusing on analyst experience is also consistent with the presence of a Matthew effect in that higher-status actors (i.e. more experienced and therefore, more successful analysts) are likely to be more protected for infringing norms than lower-status actors (Podolny, 1993; Rao, 1994; Durand et al., 2007); therefore, they are more likely to switch behaviour to conform to an alternative emerging 
institutional logic, that potentially weakens a previously established one. Empirically, work by Phillips and Zuckerman (2001) shows that higher-status actors - in their case, Silicon Valley law firms and analysts are more likely to defy prevailing norms and role prescriptions, since they enjoy a higher degree of security in their role incumbency. Indeed, Phillips and Zuckerman (2001) even postulate a U-shaped relationship between status and conformity, arguing that low-status actors may feel free to defy accepted practice and are also likely to deviate from expected norms since they have little to lose and are excluded regardless of their actions (p. 380).

However, Hong et al. (2000) empirically document that analysts with less experience (equivalently, lower status) are more likely to exhibit herding behavior (i.e. to conform), and thus, they are more likely to be terminated due to inaccurate forecasts. In our context, fewer years of experience and resulting herding behavior would therefore be associated with a higher likelihood of conforming to the prevailing agency logic, and therefore a lower likelihood of shifting towards more optimistic recommendations when a new logic in the form of a stakeholder orientation begins to emerge. Relatedly, Mikhail et al. (2003) find that analysts who have more firm-specific forecasting experience generate more accurate forecasts and positively affect the degree of information reflected in a firm's market price. Consequently, we expect that analysts with the most experience will be the first to switch from unfavorable to favorable assessments of CSR scores over time whereas, given the findings of Hong et al. (2000), we would not expect to observe deviations for the lowest-status analysts due to the higher likelihood of herding. In sum, we posit that the most experienced analysts - equivalently, highest status - are more likely to defy the norms imposed by an agency logic and consequently, they are more likely to be the first to issue more favourable recommendations for firms with high CSR scores, reflecting the emergence of an institutional focus on stakeholders. Thus, we formulate the following hypothesis:

Hypothesis 2: Over time, analysts with more experience are the first to become less pessimistic towards firms with high CSR scores. 
In addition to the analyst community, status heterogeneity across brokerage houses constitutes another important factor that may plausibly affect the interpretation of firms' CSR ratings. In particular, Phillips and Zuckerman (2001) suggest that brokerage houses may be divided into two "hemispheres": brokerage houses of higher and lower status. Although the role of the analysts across the two hemispheres is comparable, high-status brokerage houses (e.g. Goldman Sachs) are more likely to cater primarily to the needs of large corporations and institutional investors whereas a low-status brokerage house is more likely to cater to the needs of individual or 'retail' investors and various niche clientele (p.394) (Eccles \& Crane, 1987; Phillips \& Zuckerman, 2001). Thus, to be able to meet the demands and expectations of their sophisticated clientele in numerous industries, high-status brokerage houses require more resources as well as more human capital; consequently, higher status brokerage houses tend to be of larger size (Hong \& Kubik, 2003). In fact, Hong,Kubik \& Solomon (2000) classify brokerage house status according to size and confirm that larger brokerage houses enjoy higher status. In addition, Stickel (1995) provides evidence that capital market participants respond more to the buy and sell recommendations of analysts employed by large brokerage houses relative to other analysts; thus documenting the higher status and influence of large brokerage houses within financial markets. Heterogeneity in status across brokerage houses also points towards the presence of a Matthew effect in that investment recommendations by higher-status brokerage houses are likely to be more protected for infringing norms than recommendations by lower-status brokerage houses (Podolny, 1993; Rao, 1994; Durand et al., 2007). Accordingly, higher status (equivalently, larger) brokerage houses are, on average, more likely to switch behaviour and conform to the emerging stakeholder focus. Given the above discussion, we follow Hong and Kubik (2003) in approximating brokerage house status by the mean House Size constructed as the average number of analysts working at the focal brokerage house in any given year, and formulate the final hypothesis:

Hypothesis 3: Over time, analysts employed by larger brokerage houses are the first to become less pessimistic towards firms with high CSR scores.

\section{DATA, METHODS AND FINDINGS}


We build our sample by combining several databases. We collect CSR scores from KLD, analysts' recommendations from I/B/E/S, stock market data from CRSP and accounting data from COMPUSTAT. The resulting sample includes a total of 16,064 observations with available data for all variables for the period 1993 to 2007. Although the KLD database starts in 1992, we dropped data for the first year due to the lack of I/B/E/S data that are only available after 1992. The sample increases over time and by 2007 we have data for 2,311 US companies. Across all years, 3,580 unique companies are included in the sample. We start with the firms in the KLD dataset and drop firms for one of three reasons: a) analysts' recommendations were not available or forecast errors could not be calculated based on data from I/B/E/S or b) stock market data were not available via CRSP or c) accounting data were not available through COMPUSTAT.

Analytically, the model that we estimate at the firm-year level of analysis is:

$$
\text { meanrec }_{i t}=\boldsymbol{\beta}_{1} \text { totstr }_{i t}+\boldsymbol{\beta}_{2} \boldsymbol{X}_{i t}+\boldsymbol{\beta}_{3} \boldsymbol{Y}_{i t-1}+\boldsymbol{\delta} \boldsymbol{Z}_{i}+\varepsilon_{i t}
$$

where, $\boldsymbol{\beta}_{1}$ is the coefficient of interest, $\boldsymbol{X}_{i t}$ is a vector of control variables for firm $i$ in year $t$ including Total Relative CSR Concerns, Number of Analysts, Mean House Size, and Long-term Forecast Error; $\boldsymbol{Y}_{i t-1}$ is a vector of (lagged) control variables for firm $i$ in year $t$ - 1 including Market Value (size), Market Adjusted Returns, Intangibles, Return-on-Assets, Earnings-to-Price-ratio, Book-to-Market Ratio and Capital Expenditure; and $\boldsymbol{Z}_{i}$ is a vector of fixed effects to capture constant effects of firm and year.

We use the consensus (i.e. mean) investment recommendation (Mean Analysts' Recommendation) for each firm $i$ in the month of March of year $t$ as the dependent variable of our empirical specifications ( meanrec $_{i t}$ ). The I/B/E/S database records analysts' investment recommendations on a five-point scale with 1 indicating a "strong buy" recommendation and a 5 indicating a "sell" recommendation. We invert this scale so that more favorable recommendations take a higher value. This variable is constructed by I/B/E/S and reported in the consensus files. Essentially, for a given firm in the focal year, I/B/E/S first collects all published analyst recommendations (in our case, for the month of March) and then constructs an equally weighted average. Accordingly, for the focal firm in the focal year, our dependent variable is the average 
of all the investment recommendations published by the analysts that follow the firm. I/B/E/S reports consensus recommendations on the third Friday of each month and we select the March dataset in each year to ensure that analysts have had enough time to obtain and analyze the firm-level CSR scores. We fit panel data models that incorporate firm and year fixed effects exploiting within firm variation, and controlling for time-invariant unobservable firm attributes.

In recent years, CSR scores provided by KLD have been widely used in the academic literature (e.g. Graves \& Waddock, 1994; Turban \& Greening, 1997; Fisman, Heal, \& Nair, 2005; Mattingly \& Berman, 2006; Godfrey, Merrill, \& Hansen, 2009) and have in fact contributed towards the high proliferation of CSR-related articles (Margolis et al., 2007). ${ }^{9}$ In our work, we use the KLD STATS product. ${ }^{10}$ KLD provides CSR scores annually over the course of 15 years, making it an excellent data resource for exploring longitudinal CSR research questions. Researchers at KLD review the company's public documents, including the annual report, the company website, corporate social responsibility reporting, and other stakeholders' and data sources. Company ratings represent a snapshot of the firm's CSR profile at calendar year end. KLD researchers also monitor media sources for developing issues on a daily basis. The KLD STATS dataset is compiled around the beginning of every year (i.e. January) and it is typically available in spreadsheets for distribution at the latest by early February. As we mention above, to allow enough time for analysts to review these scores, we consider analyst recommendations for the month of March (i.e. the month after the release of the KLD scores). ${ }^{11}$. Their historical ratings data set is

\footnotetext{
${ }^{9}$ Studies have shown that this dataset exhibits robust construct validity around its underlying measures (e.g., (Scharfman, 1996; Szwajkowski \& Figlewicz, 1999; Mattingly \& Berman, 2006)). More recently, however scholars have raised criticisms around aspects of the dataset. For example, (Chatterji, Levine, \& Toffel, 2009) find "little evidence that KLD's environmental strengths predicted any of the environmental outcomes" they analysed (p.162) although stating that "KLD environmental ratings do a reasonable job of aggregating past environmental performance" and that "the single KLD net environmental score (environmental strengths ratings minus environmental concerns ratings) and KLD's total environmental concerns ratings helped predict future pollution levels, the value and number of subsequent regulatory penalties, and whether firms eventually reported any major spills (p.162).

${ }^{10}$ For a detailed description of the various screens and criteria included in KLD STATS the interested reader can have a look at KLD's website at (www.kld.com) and more information about the specific database product we use at (http://www.kld.com/research/stats/index.html)

${ }^{11}$ In unreported results, and as a robustness check, we have also rerun our specifications using the April recommendations, allowing more time for the analysts to review the CSR scores, with virtually no changes in our findings.
} 
designed primarily as a binary system. For each strength (i.e. a positive screen) or concern (i.e. a negative screen) rating applied to a company, KLD includes a "1" indicating the presence of that screen/criterion and a " 0 " indicating its absence. In total, six issue areas are included: a) Community, b) Corporate Governance, c) Diversity, d) Employee Relations, e) Product and f) Environmental Issues.

One issue faced by scholars that have used the KLD database in the past is how to construct a composite CSR measure. In other words, how to assign weights to the six issue areas covered in the database. Some articles have utilized differential category weights based on either (subjective) academic opinions about category importance (Graves \& Waddock, 1994; Waddock \& Graves, 1997) or have used the analytic hierarchy process to derive weights (Ruf, Muralidhar, \& Paul, 1993). To date however, the literature has not identified a theoretically derived ranking of importance for the various stakeholder groups and issues to serve as a guide for empirical work. In fact, (Mitchell, Agle, \& Wood, 1997) argue that finding such a universal ranking is not even theoretically possible. In this paper, we follow the convention established by Waddock and Graves (1997) and Sharfman (1996), followed by Hillman \& Keim (2001) and Waldman,Siegel \& Javidan (2006) among many others, in developing a composite CSR score by assigning equal importance (and thus equal weights) to the different issue areas of the KLD database. In particular, Total CSR Strengths (totstr ${ }_{i t}$ ) is the equally-weighted sum of KLD's positive screens, classified as "strengths", for firm $i$ in year $t$ adjusted by the mean of strengths averaged across all firms in the sample in year $t$ to take into account firm entry into the KLD panel. In doing so, we also account for the trending of CSR ratings within our sample. ${ }^{12}$

Similarly, we construct Total CSR Concerns as a control variable, by deriving an equally-weighted sum of KLD's negative screens, classified as "concerns" for each firm in each year of our sample. By distinguishing between CSR strengths and concerns, we follow several recent articles (e.g. Strike, Gao, \& Bansal, 2006; Kacperczyk, 2009; Bear, Rahman, \& Post, 2010) in arguing that CSR and CSiR (Corporate

\footnotetext{
${ }^{12}$ We also used another specification, where we averaged across firms within the same industry in the same year with virtually no impact on our results.
} 
Social Irresponsibility) are two theoretically separate and distinct constructs and should be treated as such empirically. Indicatively, Godfrey et al. (2009) argue that the qualitative choice of engagement in CSR is distinct from incurring negative fines or penalties, which they label as "negative social impacts". Whereas few prior articles have constructed a single CSR score by subtracting total concerns from total strengths (e.g. Slater \& Dixon-Fowler, 2009; Manner, 2010), we do not adopt this approach in our empirical analysis because the theoretical rationale that we developed pertains specifically to the strategic choice of corporations to engage in positive CSR (in order to meet stakeholder expectations) and how such policies are interpreted and evaluated by investment analysts. Equivalently, we consider such a single measure of CSR to be problematic since it is merging together fundamentally different and perhaps conflicting underlying mechanisms: "doing good" is theoretically and strategically different from "doing no harm".

We include several other control variables identified in prior literature as determinants of firm performance and/or influencing investment recommendations. Following a number of prior articles (e.g. Zuckerman, 1999) we control for the total number of analysts (Number of Analysts) who follow the firm in the focal year; similar to the case of critics in other markets (Shrum, 1996; Eliashberg \& Shugan, 1997), the extent of analyst attention, as opposed to the specialization of their coverage, has been shown to affect firm value (Zuckerman, 1999). We obtain one recommendation per analyst per firm in the focal year therefore the number of analysts is the same as the number of investment recommendations for the focal firm in the focal year. The natural logarithm of Market Value of equity is a proxy for firm size and is also lagged by one year. Analysts might issue more favorable recommendations for larger firms since trading in these firms generates more trading commissions and these firms are more likely to generate investment banking business. The two revenues are the primary source of analyst compensation thereby incentivizing analysts to be more optimistic about these companies. Market-adjusted return is the one-year lagged stock return for the company over a fiscal year minus the stock return on the value-weighted index. We expect better performing stocks to have more positive recommendations reflecting the tendency of analysts to chase stock returns (Jegadeesh, Kim, Krische et al., 2004). Moreover, we include two control variables to 
account for analysts' characteristics: a) Mean House Size calculated as the average number of employees for all the brokerage houses that employ an investment analyst who follows the focal firm, thus proxying for the availability of resources that the analyst has at her disposal to perform her research (Clement, 1999) and b) Long Term Forecast Error measuring the average long-term forecast error of the investment analysts that follow the focal firm and which captures the mean analyst ability in terms of how accurately they can predict a firm's long-term performance (e.g. Mikhail, Walther, \& Willis, 1997; Hong et al., 2000; Clement \& Tse, 2005; Loh \& Mian, 2006). We adopt the standard methodology in the literature whereby the longterm forecast error is defined and calculated as the realized long-term growth in earnings minus the analysts' forecast of long-term growth in earnings. According to I/B/E/S, long-term growth forecasts are received directly from contributing analysts, and are not calculated by I/B/E/S. It generally represents an expected annual increase in operating earnings over the company's next full business cycle. These forecasts typically refer to a period of between three to five years.

We also include several time-varying firm characteristics that might influence analyst recommendations and that control for the performance implications of other strategic actions of the firm. First, we include two valuation ratios, (one-year lagged) earnings over price (Earnings-to-price ratio) and (one-year lagged) shareholder's book value over market value of equity (Book-to-market ratio). We expect that all else equal, analysts will issue more favorable recommendations for firms with higher valuation ratios (Jegadeesh et al., 2004). Second, we include controls for the profitability of the firm measured as one-year lagged Return-on-assets (ROA), one-year lagged percentage of assets that are Intangibles, and Capital expenditures as percentage of total assets. The latter two variables identify firms that grow either by acquisitions or by investing in capital projects. We expect positive coefficients on all three variables (Jegadeesh et al., 2004). Finally, we estimate the model by including year and firm fixed effects $\left(Z_{i}\right)$. We cluster standard errors at the company level to mitigate serial correlation within a firm. We highlight here that the panel data design of our regression analysis coupled with the firm and year fixed effects, allows us to condition on the within-firm changes over time instead of the between-firm variation. This is particularly 
relevant and important for testing our theory where estimation of the coefficients of interest is based on longitudinal variation.

\section{Descriptive Statistics}

Table 1 panel A presents summary statistics for the variables used in our analysis. On average, a firm in our sample has one CSR strength. However, considerable variation exists since the sample includes firms with zero all the way to 15 CSR strengths; the standard deviation is approximately 1.5 . The summary statistics also show that our sample includes mainly large firms who are followed by several analysts; on average there are about 11 investment recommendations per firm. Fourteen percent of the assets of the average company are intangibles and the average company is profitable (mean $\mathrm{ROA}=8.2 \%$ ). Moreover, Table 1 panel B provides additional descriptive statistics pertaining to the analysts' recommendations included in the sample. Specifically, the second column of the panel presents the average number of years of firm-specific experience that an analyst has in any given year. The rest of the columns report this average broken down by type of recommendation (whereby, 1 = "strong buy" and 5 = "strong sell"). We note an upward trend in the data due to the passing of time and thus, the accumulation of analyst experience, and also due to the increased number of unique firms covered in the sample across years.

Insert Table 1 about here

Table 2 presents pair-wise correlations between the variables used in our empirical analysis. Total CSR Strengths is negatively correlated with Mean Analyst Recommendation, indicating that on average, across years and across firms, the analysts in our sample were unfavorable towards CSR ratings. In terms of our control variables, Firm size and Number of Analysts have a strong positive correlation with Total CSR Strengths as we would expect. Interestingly, the two controls for analyst ability, Mean House Size and Long-term Forecast Error, are significantly negatively correlated with our dependent variable. Our theoretical arguments however, are longitudinal in nature, and therefore the subsequent multivariate analysis directly tests our hypotheses. 
Insert Table 2 about here

Results

In table 3 panel B we present the main findings of estimating equation (1) on the full sample. In particular, the first column of table 3 panel B estimates this equation on the first bundle of years that includes observations for the period 1993-1996; each subsequent column adds an additional year to the data (i.e. the second column estimates equation (1) for the period 1993-1997, the third, 1993-1998 and so forth). Accordingly, the last column presents estimation results for equation (1) for the entire period $1993-2007$ covered in our sample. The independent variable of interest is Total CSR Strengths. We estimate the model on these different bundles of years to detect how the relation changes over time. Hypothesis 1 therefore predicts that the coefficient on Total CSR Strengths would initially be negative and increasingly less negative (or eventually positive). The estimates confirm this prediction. Graphically, figure 1 depicts the estimated coefficient on Total CSR Strengths and shows that as time goes by analysts' reactions to CSR scores become increasingly less unfavorable, and eventually become favorable.

It is important to note that the number of unique firms increases across the columns of table 3 panel B because KLD progressively expanded their coverage over our sample period. However, it is unlikely that these changes would affect the findings since the specifications include firm fixed effects, and therefore the coefficients are estimated from within firm variance over time rather than cross-sectional variation. Nevertheless, we proceed to construct a relatively more balanced panel by limiting our sample to only include firms that were present for at least 10 years of the sample period (i.e. two thirds of the time) obtaining 295 firms for 1993-1996, and ranging from 318 to 356 for the remaining time periods. We report these findings as table 3 panel A, and since the estimates are qualitatively similar between panel A and panel B, we consider panel A as our main results.

Moreover, we note that as expected, in the last couple of columns of table 3, panel A the coefficient on Total CSR Strengths becomes statistically insignificant. The insignificance emerges because over time, 
the underlying pooled data confounds the shifting perception of CSR scores by investment analysts; this particularly applies for the columns where we pool data for the entire period 1993-2007 covered in our sample. Finally, we note that the coefficient on Total CSR Concerns remains predominantly insignificant across specifications, and does not follow any discernible pattern over time. This implies, as we suggest in our theoretical development section, that the shifting institutional logic from an agency to a stakeholder perspective is much more likely to affect pro-active CSR initiatives that are undertaken to meet the needs and expectations of a wider range of stakeholder and are therefore perceived as potentially mitigating risks or even generating firm value. On the other hand, investment analysts would unfavorably assess CSR shortfalls and failures, whether these are perceived as an agency cost or as value-destructing activities. The directionality of this argument appears to be supported in table 3 panel B: whenever statistically significant, the coefficient on Total CSR Concerns is in fact negative.

Insert Table 3

Hypothesis 2 argues that more experienced analysts are more likely to be the first to switch from unfavorable to favorable evaluations of firms with high CSR scores. Based on the full sample, we calculate analyst experience as the total number of years that the focal analyst has followed the focal firm. Panel A of table 4 replicates the models of table 3 (panel B) but confines the sample to the top two quartiles of analyst experience whereas Panel B confines the sample to the bottom two quartiles of analyst experience. Confirming hypothesis 2 , the estimated coefficients indicate that the more experienced analysts issue more favorable recommendations (equivalently, less unfavorable) over time and by the end of our sample period (last three columns of table 4, panel A) their evaluations of firms with high CSR strengths become significantly positive. In contrast, for the bottom two quartiles of analyst experience, assessment of CSR scores remains unfavorable for the entire 1993 - 2007 period, although the estimated coefficient does become somewhat less unfavorable over time. Graphically, figure 2 plots the estimated coefficients for the top two and the bottom two quartiles of analyst experience, and shows that not only do the more experienced 
analysts switch first to favorable recommendations but also, that they more rapidly adjust their recommendations (i.e. the curve for the top two quartiles appears steeper than the one for the bottom two quartiles of analyst experience). Similarly, table 5 tests hypothesis 3 according to which analysts employed by larger brokerage houses are more likely to be the first to switch from unfavorable to favorable evaluations of firms with high CSR scores. Accordingly, panels A and B replicate the models of table 3 but this time the sample is confined to the top two and bottom two quartiles of the mean House Size, respectively. Consistent with our hypothesis, we find that analysts employed by larger brokerage houses are more likely to switch to favorable evaluations of firms with high CSR scores, over time.

Insert Tables 4 and 5 about here

\section{Alternative Explanation: Learning by Analysts}

A plausible alternative explanation for the findings presented here is that, over time, analysts learn to evaluate CSR ratings by better understanding how CSR may contribute towards risk mitigation or value creation. If this were indeed the case, analysts would be relatively pessimistic about the future profitability of firms with high CSR scores and relatively optimistic about the future profitability of firms with low CSR scores during the early periods of our sample. This underlying learning argument then, may plausibly generate the pattern that we observe in the findings without the need to account for a potential shift in the prevailing institutional logic (thus, generating a spurious correlation in table 3). A plethora of both theoretical and empirical articles (e.g. Mikhail et al., 1997; Hong et al., 2000; Clement \& Tse, 2005; Loh \& Mian, 2006) model analysts' learning using Analyst Forecast Error; we follow this tradition here as well. The main idea behind this metric is that if analysts are learning how to better evaluate a focal CSR policy over time, then their earnings forecasts will increasingly become more accurate. In other words, we would expect CSR scores to be significantly associated with forecast errors in the initial period of our sample and, as analysts learn, we expect this significant association to diminish and eventually be eliminated. Panel A of table 6 replicates the specifications of table 3 but uses Analyst Forecast Error as the dependent variable. 
Because forecast errors increase with forecast horizon, we introduce a control variable for horizon in our specifications as well. We find no statistically significant association between CSR scores and forecast error for any specification across the two tables, suggesting that for the context and time period of our sample, learning by analysts does not appear to be an alternative explanation for the estimated empirical pattern of table 3 .

Insert Table 6 about here

\section{DISCUSSION AND CONCLUSION}

We explore the sociological processes that affect the evaluation of firms with high CSR scores by sell-side investment analysts in the US, over a period of 15 years. We argue and find empirical evidence that a weakening of the prevailing logic - the agency logic - and the gradual emergence of a stakeholder focus, leads to an initial unfavorable and a subsequent more favorable evaluation of firms with high CSR scores by investment analysts. Whereas under an agency logic CSR was typically interpreted as an activity that primarily generated managerial returns or satisfied managerial aspirations to the detriment of corporate profitability (i.e. an agency cost), under a stakeholder logic, CSR is conceptualized as a set of corporate policies essential to corporate standing that does not penalize a firm's financial performance and may even generate financial value in the long-run. Our article provides insights into the assessment of firms with high CSR ratings, and suggests that firms may adopt CSR without being penalized by a key third party in the financial markets, namely sell-side analysts.

As mentioned at the outset of this article, an emerging strand of literature has focused on the relationship between CSR and financial markets but without explicitly taking into account the sociological processes that affect the assessment of firms' CSR ratings. According to extensive prior literature, in financial markets such sociological processes have a direct and measurable impact on firm value (Phillips \& Zuckerman, 2001; Zajac \& Westphal, 2004) making this an important gap that needs to be addressed. Such sociological processes are particularly relevant for the domain of CSR where stakeholder expectations 
and external assessments by third parties are especially salient. With this paper we begin to fill this gap in our understanding by introducing the idea that the prevailing agency logic was weakened by the gradual emergence of a stakeholder orientation within the analyst and investor community.

The findings of this article also provide support to the institutional perspective that focuses on how financial markets perceive and assess policies such as those related to CSR. The theoretical arguments, as well as the empirical evidence presented here provide additional support for the influence of historical change on the dominant belief system or institutional logic of key market actors. Furthermore, we are able to provide evidence that market actors who possess more experience or enjoy higher status are more likely to be the first to adjust their assessments based on this new and emergent logic. We therefore contribute to the sociological research that focuses on understanding the macro-historical and institutional changes in the context, to the literature that focuses on the micro-social dynamics of financial markets (Abolafia, 1996; Westphal \& Zajac, 1998; Zuckerman, 1999) and to the more recent literature exploring the inputs to the social estimation process that drives stock market valuation (Zajac \& Westphal, 2004).

Our work also closely relates to a recent stream of work in management (Benner, 2007, 2010; Benner \& Ranganathan, 2012) that explores the reactions of investment analysts to the adoption of specific firm strategies during times of radical technological change. In fact, these articles find that such reactions exert pressures on firms and significantly affect their subsequent adoption of strategies. Given that in this article we find an increasingly less unfavorable assessment of CSR ratings by analysts, especially by those of higher experience and higher status, exploring how this shift in institutional logics will affect the subsequent adoption of CSR by firms becomes an interesting avenue of future research. It would also be important to understand the specific mechanisms through which such pressures are exerted on firms and which firms are more likely to respond to them and in what ways. For example, some firms may increasingly engage in CSR by ceremonially conforming to such pressures - in the form of symbolic actions - whereas others may realize the value-creating potential and accordingly adopt a range of substantive CSR actions. 
Whereas most of the prior work on social construction of capital markets (Zuckerman, 1999; Zajac \& Westphal, 2004) has focused on issues of governance (e.g. stock repurchase plans, or incentives provision), our work here broadens the theoretical scope of social construction theory to argue that in addition to governance issues, social construction may intrinsically affect analysts' perceptions and evaluations of social and environmental initiatives adopted by companies. Similarly, whereas the strategy literature to date has explored analysts' reactions to predominantly financial metrics or radical technological innovations, our article expands the scope of this literature as well, by exploring the impact of non-financial metrics on investment recommendations. Therefore, since CSR is considered as a set of policies adopted by corporations to meet the needs and expectations of multiple stakeholders, our study is essentially exploring how a shifting logic affects the perception and evaluation of firms' actions aimed at numerous and diverse stakeholders by a key social actor in the capital markets, namely sell-side analysts. Relatedly, we note that a fruitful avenue of future research is to develop more nuanced theory and a deeper understanding of the changing perceptions of analysts with regards to each of these stakeholders, as opposed to exploring CSR as one multi-dimensional construct.

Finally, whereas in the existing finance literature herding behavior has typically been linked to financial metrics (or, equivalently, instrumental outcomes), in this article we suggest that herding behavior may also extend to domains beyond the financial, to include environmental, social and broader CSR issues. Moreover, by exploring the heterogeneity across analysts and across brokerage houses, our article develops a more nuanced understanding of how a shifting institutional logic affects different analysts and brokerage houses differentially. Thus, to the best of our knowledge, our study is the first one to integrate across the CSR and herding and finance literatures to shed new light on a phenomenon that is increasingly gaining momentum in capital markets.

\section{Limitations and Future Research}

Despite its contributions, this article is not without its limitations; here, we highlight a few. The first, relates to the potentially changing nature of the underlying policies captured by our CSR measures. If these policies 
are themselves changing then the observed shift in sell-side analysts' recommendations can be partly attributed to such a change rather than the claimed change in the institutional logic. However, we consider this to be rather unlikely given that the policies included in our CSR measures remain stable over time. For example, diversity in the workforce, recycling of materials, and community engagement were captured and quantified in the same way throughout our sample period. Moreover, there were no redefinitions of the underlying constructs used in our analysis during our sample period. The second caveat relates to the changing characteristics of the sell-side analyst profession itself. If sell-side analysts exhibit fundamentally different individual characteristics over time, in terms of gender, educational background, social class, to name a few, then these changing attributes could partly explain the changing assessment of CSR scores. However, prior work that has explored ties formed across analysts based on common educational backgrounds Cohen et al. (2010) does not appear to detect or argue for any such shifts over this time period within the analyst profession. Undoubtedly, the ideal empirical test would have been to use a sample of investment recommendations from a fixed set of sell-side analysts whom we would be able to follow for over 15 years and who would issue recommendations for the same firms. However, such long tenures are relatively rare and unusual within the sell-side analyst profession precluding us from being able to conduct this type of analysis. Thus, by not including analyst fixed effects, our current analysis derives estimates not from within-analyst variation, but rather from within-firm variation over time (since we include instead firm fixed effects). Nevertheless, we are unaware of any other existing evidence that the employee base of the sell-side analyst profession has changed systematically over the time period we study, thus making it less likely that this issue could affect our findings. Similarly, we cannot include fixed effects at the brokerage house level; instead, we include a control variable for mean house size across the analysts that follow a focal firm in each year. Therefore, a potential systematic change in ideology or house culture attributed to the institutional logic shift affecting the brokerage houses that follow a focal firm during the years of our analysis, may introduce a bias in our findings. However, to the extent that this potential bias is 
idiosyncratic to a focal firm and the brokerage houses that follow it, then this issue is accounted for by our inclusion of firm fixed effects.

The weakening of the previously dominant agency logic that we document here appears to have been taking place in the US over a 15-year horizon. A fruitful avenue for future research would be to investigate how this change in institutional logic affected the speed with which the interpretation and assessment of CSR changed by sell-side analysts in other countries. We know, for example, that some countries, including Sweden, France, the UK, Canada, and South Africa have instituted more progressive policies favoring the adoption of CSR by companies, potentially accelerating the institutional logic shift. Accordingly, future work may seek to understand the institutional processes and characteristics that affect the speed of change in assessment for the CSR context in particular, but also more broadly. In our article we document positive but relatively small associations between investment recommendations and CSR strengths in more recent years. Therefore, subsequent articles may explore the conditions and the extent to which analysts reward proactive CSR with even more favorable recommendations. It could be that in other countries or under different conditions, analysts reward firms with high CSR strengths with larger increases in investment recommendation optimism, indicating perhaps more salient and prevalent institutional logics. Relatedly, future research could explore whether, to what extent and why specific CSR dimensions and policies are more or less likely to be associated with favorable analysts' recommendations. This issue also links to the work by Delmas, Etzion \& Narn-Birch (2013) who suggest that composite measures might be misrepresentative of the underlying process and outcome dimensions of environmental (or social) performance. Accordingly, in unreported analysis, rather than using a composite CSR score as our dependent variable, we used separate variables corresponding to the KLD categories associated with a) Community, b) Corporate Governance, c) Diversity, d) Employee Relations, and e) Environmental f) Product issues to estimate the main specifications of table 3. Keeping in mind the lack of theoretical guidance regarding the relative weight and importance of specific CSR dimensions, this preliminary empirical investigation finds that a) environmental issues are beginning to be perceived more positively in 
recent years by analysts, perhaps indicating their value creating potential and b) issues of diversity (or broader social issues) are beginning to be perceived less negatively, perhaps reflecting their risk mitigation potential. To further explore this issue for our sample, we reproduced the specifications of table 6 using these six KLD categories rather than the composite CSR score as our independent variables, and we did not detect any differential learning by analysts (i.e. no significant correlation with forecast errors) across issue areas. Without a doubt, both theoretically as well as empirically, a lot more needs to be done in the future to understand the more nuanced mechanisms at work regarding how CSR categories and policies are perceived and evaluated by analysts as well as other social actors within public equity markets.

Moreover, we note that although we argue for the broader weakening of the agency logic, we do not argue for the complete emergence of an alternative logic (i.e. a complete paradigm shift). In this sense, we are not able to detect a threshold of adoption effect (Delmas \& Montes-Sancho, 2011) because arguably in the relation between CSR perceptions and financial markets, this threshold has not yet materialized. Undoubtedly though, this is another avenue for follow up research.

Finally, as we discuss in our hypotheses development section, a myriad of factors contributed to the weakening of the agency logic including mandatory and voluntary reporting, NGO activity, academic research, increasing consumer awareness, proactive corporate leadership, and socially responsible investments. Future research could try to determine which of these elements were particularly influential in this shift and through which specific mechanisms. It could be that a combination of these factors was necessary and sufficient for a change in institutional logic; or that all of them combined generated the effects we document here. Future research may also explore whether a tipping point may emerge that would eventually led to the replacement of the agency logic by the stakeholder logic. Understanding this process is particularly important at a time when even the public debate focuses on redefining the role of the corporation in society and an era in which new systems of resource allocation in the global economy - such as Sustainable Capitalism suggested by Generation investment co-founders Al Gore and David Blood - are slowly but steadily gaining traction around the world. 
Table 1 Panel A: Summary statistics (16,064 obs.)

\begin{tabular}{||l|c|c|c|c||}
\hline \hline \multicolumn{1}{|c|}{ Variable } & Mean & Std. Dev. & Min & Max \\
\hline Mean Analyst Recommendation & 3.652 & 0.520 & 1.000 & 5.000 \\
\hline Total CSR Strengths & 1.055 & 1.481 & 0.000 & 15.705 \\
& & & & \\
\hline Total CSR Concerns & 1.014 & 1.079 & 0.000 & 12.405 \\
Number of Analysts & 10.707 & 7.067 & 1.000 & 47.000 \\
Mean House Size & 64.047 & 36.638 & 1.000 & 353.000 \\
Long-Term Forecast Error & 0.005 & 0.033 & -0.446 & 0.500 \\
Market Value (Size) & 14.476 & 1.467 & 11.302 & 19.325 \\
Market Adjusted Return & 0.037 & 0.402 & -0.860 & 3.207 \\
Intangibles & 0.139 & 0.175 & 0.000 & 0.767 \\
Return on assets & 0.082 & 0.111 & -0.573 & 0.416 \\
Earnings-to-price ratio & 0.029 & 0.093 & -1.537 & 0.197 \\
Book-to-market ratio & 0.438 & 0.281 & -0.254 & 3.201 \\
Capital Expenditure & 0.049 & 0.054 & 0.000 & 0.355 \\
\hline \hline
\end{tabular}

Table 1 Panel B:

Average years of firm-specific analyst experience by year and type of recommendation $(16,064 \mathrm{obs}$.)

\begin{tabular}{||c|c||ccccc||}
\hline Year & $\begin{array}{c}\text { Average \# } \\
\text { of years of firm- } \\
\text { specific exp. }\end{array}$ & \multicolumn{5}{c||}{ Type of Recommendation } \\
\cline { 3 - 7 } & 1.43 & $\mathbf{1}$ & $\mathbf{3}$ & $\mathbf{4}$ & $\mathbf{5}$ \\
\hline 1993 & 1.79 & 2.13 & 1.76 & 1.40 & 1.38 & 1.52 \\
1994 & 2.05 & 2.43 & 1.84 & 2.03 & 2.80 & 1.77 \\
1995 & 2.21 & 2.73 & 2.42 & 2.29 & 2.16 & 2.07 \\
1996 & 2.10 \\
1997 & 2.24 & 2.27 & 2.38 & 2.26 & 2.25 & 2.19 \\
1998 & 2.35 & 2.22 & 3.02 & 2.41 & 2.36 & 2.25 \\
1999 & 2.45 & 2.50 & 2.93 & 2.49 & 2.45 & 2.40 \\
2000 & 2.40 & 2.95 & 2.47 & 2.35 & 2.39 & 2.48 \\
2001 & 2.34 & 2.32 & 2.40 & 2.27 & 2.41 & 2.35 \\
2002 & 2.48 & 2.47 & 2.73 & 2.49 & 2.49 & 2.32 \\
2003 & 2.39 & 2.51 & 2.75 & 2.45 & 2.34 & 2.21 \\
2004 & 2.42 & 2.75 & 2.70 & 2.43 & 2.34 & 2.35 \\
2005 & 2.45 & 2.61 & 2.68 & 2.51 & 2.43 & 2.23 \\
2006 & 2.49 & 2.77 & 2.84 & 2.53 & 2.40 & 2.37 \\
2007 & 2.48 & 2.74 & 2.53 & 2.47 & 2.28 & 2.66 \\
\hline \hline
\end{tabular}


Table 2: Pairwise correlation coefficients with significance level (16,064 obs.)

\begin{tabular}{|c|c|c|c|c|c|c|c|c|c|c|c|c|c|}
\hline & & $(1)$ & $(2)$ & (3) & $(4)$ & $(5)$ & $(6)$ & $(7)$ & $(8)$ & $(9)$ & $(10)$ & $(11)$ & $(12)$ \\
\hline 1 & Mean Analyst Recommendation & 1.000 & & & & & & & & & & & \\
\hline 2 & Total CSR Strengths & $\begin{array}{c}-0.043 \\
0.000\end{array}$ & 1.000 & & & & & & & & & & \\
\hline 3 & Total CSR Concerns & $\begin{array}{c}-0.040 \\
0.000\end{array}$ & $\begin{array}{l}0.370 \\
0.000\end{array}$ & 1.000 & & & & & & & & & \\
\hline 4 & Number of Analysts & $\begin{array}{l}0.017 \\
0.030\end{array}$ & $\begin{array}{l}0.338 \\
0.000\end{array}$ & $\begin{array}{l}0.286 \\
0.000\end{array}$ & 1.000 & & & & & & & & \\
\hline 5 & Mean House Size & $\begin{array}{c}-0.050 \\
0.000\end{array}$ & $\begin{array}{l}0.091 \\
0.000\end{array}$ & $\begin{array}{l}0.145 \\
0.000\end{array}$ & $\begin{array}{l}0.206 \\
0.000\end{array}$ & 1.000 & & & & & & & \\
\hline 6 & Long-term Forecast Error & $\begin{array}{c}-0.048 \\
0.000\end{array}$ & $\begin{array}{r}-0.017 \\
0.028 \\
\end{array}$ & $\begin{array}{c}-0.013 \\
0.091 \\
\end{array}$ & $\begin{array}{c}-0.068 \\
0.000 \\
\end{array}$ & $\begin{array}{l}-0.015 \\
0.064 \\
\end{array}$ & 1.000 & & & & & & \\
\hline 7 & Market Value (Size) & $\begin{array}{l}0.051 \\
0.000\end{array}$ & $\begin{array}{l}0.454 \\
0.000\end{array}$ & $\begin{array}{l}0.442 \\
0.000\end{array}$ & $\begin{array}{l}0.731 \\
0.000\end{array}$ & $\begin{array}{l}0.359 \\
0.000\end{array}$ & $\begin{array}{c}-0.086 \\
0.000\end{array}$ & 1.000 & & & & & \\
\hline 8 & Market Adjusted Return & $\begin{array}{l}0.172 \\
0.000 \\
\end{array}$ & $\begin{array}{c}-0.025 \\
0.001 \\
\end{array}$ & $\begin{array}{l}0.005 \\
0.512 \\
\end{array}$ & $\begin{array}{c}-0.024 \\
0.003 \\
\end{array}$ & $\begin{array}{l}0.028 \\
0.000 \\
\end{array}$ & $\begin{array}{c}-0.124 \\
0.000 \\
\end{array}$ & $\begin{array}{l}0.056 \\
0.000 \\
\end{array}$ & 1.000 & & & & \\
\hline 9 & Intangibles & $\begin{array}{l}0.056 \\
0.000\end{array}$ & $\begin{array}{c}-0.029 \\
0.000\end{array}$ & $\begin{array}{l}0.007 \\
0.355\end{array}$ & $\begin{array}{r}-0.009 \\
0.274\end{array}$ & $\begin{array}{l}0.056 \\
0.000\end{array}$ & $\begin{array}{l}0.001 \\
0.910\end{array}$ & $\begin{array}{l}0.013 \\
0.097\end{array}$ & $\begin{array}{c}-0.045 \\
0.000\end{array}$ & 1.000 & & & \\
\hline 10 & Return on assets & $\begin{array}{l}0.075 \\
0.000 \\
\end{array}$ & $\begin{array}{l}0.068 \\
0.000 \\
\end{array}$ & $\begin{array}{l}0.021 \\
0.008 \\
\end{array}$ & $\begin{array}{l}0.145 \\
0.000 \\
\end{array}$ & $\begin{array}{l}0.089 \\
0.000 \\
\end{array}$ & $\begin{array}{c}-0.088 \\
0.000\end{array}$ & $\begin{array}{l}0.281 \\
0.000 \\
\end{array}$ & $\begin{array}{l}0.102 \\
0.000 \\
\end{array}$ & $\begin{array}{l}0.086 \\
0.000\end{array}$ & 1.000 & & \\
\hline 11 & Earnings-to-price ratio & $\begin{array}{l}0.061 \\
0.000\end{array}$ & $\begin{array}{l}0.035 \\
0.000\end{array}$ & $\begin{array}{l}0.013 \\
0.097\end{array}$ & $\begin{array}{l}0.030 \\
0.000\end{array}$ & $\begin{array}{l}0.028 \\
0.001\end{array}$ & $\begin{array}{c}-0.161 \\
0.000\end{array}$ & $\begin{array}{l}0.166 \\
0.000\end{array}$ & $\begin{array}{l}0.093 \\
0.000\end{array}$ & $\begin{array}{c}-0.040 \\
0.000\end{array}$ & $\begin{array}{l}0.450 \\
0.000\end{array}$ & 1.000 & \\
\hline 12 & Book-to-market ratio & $\begin{array}{c}-0.213 \\
0.000\end{array}$ & $\begin{array}{c}-0.077 \\
0.000\end{array}$ & $\begin{array}{c}-0.003 \\
0.756\end{array}$ & $\begin{array}{c}-0.184 \\
0.000\end{array}$ & $\begin{array}{l}0.009 \\
0.262\end{array}$ & $\begin{array}{l}0.198 \\
0.000\end{array}$ & $\begin{array}{l}-0.221 \\
0.000\end{array}$ & $\begin{array}{c}-0.180 \\
0.000\end{array}$ & $\begin{array}{c}-0.012 \\
0.125\end{array}$ & $\begin{array}{c}-0.217 \\
0.000\end{array}$ & $\begin{array}{c}-0.014 \\
0.076\end{array}$ & 1.000 \\
\hline 13 & Capital Expenditure & $\begin{array}{l}0.089 \\
0.000\end{array}$ & $\begin{array}{c}-0.032 \\
0.000\end{array}$ & $\begin{array}{l}0.024 \\
0.002\end{array}$ & $\begin{array}{l}0.120 \\
0.000\end{array}$ & $\begin{array}{l}0.008 \\
0.301\end{array}$ & $\begin{array}{c}-0.003 \\
0.740\end{array}$ & $\begin{array}{l}0.036 \\
0.000\end{array}$ & $\begin{array}{l}0.006 \\
0.479\end{array}$ & $\begin{array}{c}-0.177 \\
0.000\end{array}$ & $\begin{array}{l}0.164 \\
0.000\end{array}$ & $\begin{array}{l}0.009 \\
0.277\end{array}$ & $\begin{array}{c}-0.104 \\
0.000\end{array}$ \\
\hline
\end{tabular}


Table 3 - Panel A: OLS regression analysis - Impact on mean analysts' recommendations, adding years (Balanced Sample)

\begin{tabular}{|c|c|c|c|c|c|c|c|c|c|c|c|c|}
\hline & \multicolumn{12}{|c|}{ Time Period } \\
\hline Dependent Variable & $\begin{array}{l}\text { 1993-96 } \\
\text { meanrec }\end{array}$ & $\begin{array}{l}\text { 1993-97 } \\
\text { meanrec }\end{array}$ & $\begin{array}{l}\text { 1993-98 } \\
\text { meanrec }\end{array}$ & $\begin{array}{l}\text { 1993-99 } \\
\text { meanrec }\end{array}$ & $\begin{array}{l}\text { 1993-00 } \\
\text { meanrec }\end{array}$ & $\begin{array}{l}1993-01 \\
\text { meanrec }\end{array}$ & $\begin{array}{l}1993-02 \\
\text { meanrec }\end{array}$ & $\begin{array}{l}\text { 1993-03 } \\
\text { meanrec }\end{array}$ & $\begin{array}{l}\text { 1993-04 } \\
\text { meanrec }\end{array}$ & $\begin{array}{l}1993-05 \\
\text { meanrec }\end{array}$ & $\begin{array}{l}\text { 1993-06 } \\
\text { meanrec }\end{array}$ & $\begin{array}{l}1993-07 \\
\text { meanrec }\end{array}$ \\
\hline Total CSR Strengths & $\begin{array}{c}-0.074 * * * \\
(0.026) \\
\end{array}$ & $\begin{array}{c}-\mathbf{0 . 0 6 4} * * * * \\
(0.024) \\
\end{array}$ & $\begin{array}{c}-\mathbf{0 . 0 5 0} * * \\
(\mathbf{0 . 0 2 0}) \\
\end{array}$ & $\begin{array}{c}-\mathbf{- 0 . 0 3 8} * * * \\
(0.019) \\
\end{array}$ & \begin{tabular}{|c|}
$-0.033 *$ \\
$(0.018)$ \\
\end{tabular} & $\begin{array}{c}-0.016 \\
(0.014) \\
\end{array}$ & \begin{tabular}{|c|}
$\mathbf{- 0 . 0 1 6}$ \\
$(0.014)$ \\
\end{tabular} & $\begin{array}{c}0.001 \\
(0.011) \\
\end{array}$ & $\begin{array}{c}0.005 \\
(0.011) \\
\end{array}$ & $\begin{array}{c}\mathbf{0 . 0 0 1} \\
(\mathbf{0 . 0 0 9 )} \\
\end{array}$ & $\begin{array}{c}\mathbf{0 . 0 0 2} \\
(\mathbf{0 . 0 0 9 )} \\
\end{array}$ & $\begin{array}{c}\mathbf{0 . 0 0 2} \\
(\mathbf{0 . 0 0 7}) \\
\end{array}$ \\
\hline Total CSR Concerns & $\begin{array}{l}-0.023 \\
(0.020)\end{array}$ & $\begin{array}{l}-0.019 \\
(0.017)\end{array}$ & $\begin{array}{l}-0.001 \\
(0.015)\end{array}$ & $\begin{array}{l}-0.001 \\
(0.014)\end{array}$ & $\begin{array}{l}-0.001 \\
(0.014)\end{array}$ & $\begin{array}{c}0.004 \\
(0.012)\end{array}$ & $\begin{array}{c}0.004 \\
(0.013)\end{array}$ & $\begin{array}{c}0.001 \\
(0.012)\end{array}$ & $\begin{array}{l}-0.005 \\
(0.011)\end{array}$ & $\begin{array}{l}-0.004 \\
(0.010)\end{array}$ & $\begin{array}{l}-0.002 \\
(0.010)\end{array}$ & $\begin{array}{l}-0.001 \\
(0.009)\end{array}$ \\
\hline Number of Analysts & $\begin{array}{c}0.001 \\
(0.005)\end{array}$ & $\begin{array}{l}-0.003 \\
(0.004)\end{array}$ & $\begin{array}{l}-0.001 \\
(0.004)\end{array}$ & $\begin{array}{l}-0.000 \\
(0.003)\end{array}$ & $\begin{array}{l}-0.004 \\
(0.003)\end{array}$ & $\begin{array}{l}-0.005^{*} \\
(0.003)\end{array}$ & $\begin{array}{c}-0.006 * * \\
(0.003)\end{array}$ & $\begin{array}{l}-0.005^{*} \\
(0.003)\end{array}$ & $\begin{array}{l}-0.004 * \\
(0.003)\end{array}$ & $\begin{array}{c}-0.005 * * \\
(0.002)\end{array}$ & $\begin{array}{c}-0.005 * * \\
(0.002)\end{array}$ & $\begin{array}{c}-0.006 * * \\
(0.002)\end{array}$ \\
\hline Mean House size & $\begin{array}{l}-0.000 \\
(0.000)\end{array}$ & $\begin{array}{l}-0.001 \\
(0.000)\end{array}$ & $\begin{array}{c}0.000 \\
(0.000)\end{array}$ & $\begin{array}{l}-0.000 \\
(0.000)\end{array}$ & $\begin{array}{l}-0.000 \\
(0.000)\end{array}$ & $\begin{array}{l}-0.000 \\
(0.000)\end{array}$ & $\begin{array}{c}-0.000^{*} \\
(0.000)\end{array}$ & $\begin{array}{c}-0.001 * * \\
(0.000)\end{array}$ & $\begin{array}{c}-0.001 * * \\
(0.000)\end{array}$ & $\begin{array}{c}-0.001 * * * \\
(0.000)\end{array}$ & $\begin{array}{c}-0.001 * * * * \\
(0.000)\end{array}$ & $\begin{array}{c}-0.001 * * * \\
(0.000)\end{array}$ \\
\hline Long Term Forecast Error & $\begin{array}{c}0.016 \\
(1.338)\end{array}$ & $\begin{array}{l}-0.569 \\
(1.337)\end{array}$ & $\begin{array}{l}-0.445 \\
(0.932)\end{array}$ & $\begin{array}{l}-0.527 \\
(0.635)\end{array}$ & $\begin{array}{c}0.162 \\
(0.498)\end{array}$ & $\begin{array}{l}0.719^{*} \\
(0.432)\end{array}$ & $\begin{array}{l}-0.020 \\
(0.557)\end{array}$ & $\begin{array}{l}-0.196 \\
(0.583)\end{array}$ & $\begin{array}{c}-0.228 \\
(0.541)\end{array}$ & $\begin{array}{l}-0.035 \\
(0.526)\end{array}$ & $\begin{array}{l}-0.022 \\
(0.418)\end{array}$ & $\begin{array}{l}-0.150 \\
(0.424)\end{array}$ \\
\hline Market Value (Size) & $\begin{array}{c}0.303 * * * \\
(0.082)\end{array}$ & $\begin{array}{c}0.265^{* * * *} \\
(0.060)\end{array}$ & $\begin{array}{c}0.143 * * * \\
(0.047)\end{array}$ & $\begin{array}{l}0.064^{*} \\
(0.038)\end{array}$ & $\begin{array}{c}0.097 * * * \\
(0.035)\end{array}$ & $\begin{array}{c}0.117 * * * \\
(0.033)\end{array}$ & $\begin{array}{c}0.128 * * * \\
(0.031)\end{array}$ & $\begin{array}{c}0.121 * * * \\
(0.029)\end{array}$ & $\begin{array}{c}0.113 * * * \\
(0.027)\end{array}$ & $\begin{array}{c}0.109 * * * \\
(0.027)\end{array}$ & $\begin{array}{c}0.115 * * * \\
(0.026)\end{array}$ & $\begin{array}{c}0.121 * * * \\
(0.025)\end{array}$ \\
\hline Market Adjusted Return & $\begin{array}{c}0.136 * * * \\
(0.043)\end{array}$ & $\begin{array}{c}0.142 * * * \\
(0.034)\end{array}$ & $\begin{array}{c}0.139 * * * \\
(0.031)\end{array}$ & $\begin{array}{c}0.100 * * * \\
(0.021)\end{array}$ & $\begin{array}{c}0.142 * * * \\
(0.018)\end{array}$ & $\begin{array}{c}0.145 * * * \\
(0.017)\end{array}$ & $\begin{array}{c}0.158 * * * \\
(0.017)\end{array}$ & $\begin{array}{c}0.181^{* * * *} \\
(0.019)\end{array}$ & $\begin{array}{c}0.187 * * * \\
(0.019)\end{array}$ & $\begin{array}{c}0.178 * * * \\
(0.019)\end{array}$ & $\begin{array}{c}0.172 * * * \\
(0.018)\end{array}$ & $\begin{array}{c}0.180 * * * \\
(0.018)\end{array}$ \\
\hline Intangibles & $\begin{array}{c}0.143 \\
(0.289)\end{array}$ & $\begin{array}{c}0.085 \\
(0.205)\end{array}$ & $\begin{array}{c}0.230 \\
(0.172)\end{array}$ & $\begin{array}{c}0.256 \\
(0.160)\end{array}$ & $\begin{array}{c}0.183 \\
(0.150)\end{array}$ & $\begin{array}{c}0.166 \\
(0.134)\end{array}$ & $\begin{array}{c}0.251 * * \\
(0.123)\end{array}$ & $\begin{array}{c}0.280 * * \\
(0.127)\end{array}$ & $\begin{array}{l}0.244^{*} \\
(0.126)\end{array}$ & $\begin{array}{c}0.279 * * \\
(0.122)\end{array}$ & $\begin{array}{c}0.286 * * \\
(0.114)\end{array}$ & $\begin{array}{c}0.340 * * * \\
(0.108)\end{array}$ \\
\hline Return on Assets & $\begin{array}{c}0.436 \\
(0.474)\end{array}$ & $\begin{array}{c}0.451 \\
(0.413)\end{array}$ & $\begin{array}{l}0.633^{*} \\
(0.349)\end{array}$ & $\begin{array}{c}0.878 * * \\
(0.341)\end{array}$ & $\begin{array}{l}1.245 * * * \\
(0.295)\end{array}$ & $\begin{array}{c}1.002 * * * \\
(0.255)\end{array}$ & $\begin{array}{c}0.845 * * * \\
(0.239)\end{array}$ & $\begin{array}{c}0.654 * * * \\
(0.240)\end{array}$ & $\begin{array}{c}0.528 * * \\
(0.233)\end{array}$ & $\begin{array}{c}0.528 * * \\
(0.225)\end{array}$ & $\begin{array}{c}0.507 * * \\
(0.219)\end{array}$ & $\begin{array}{c}0.430^{* *} \\
(0.206)\end{array}$ \\
\hline Earnings-to-price ratio & $\begin{array}{c}0.076 \\
(0.337)\end{array}$ & $\begin{array}{c}0.079 \\
(0.292)\end{array}$ & $\begin{array}{l}-0.017 \\
(0.257)\end{array}$ & $\begin{array}{c}0.172 \\
(0.232)\end{array}$ & $\begin{array}{l}-0.267 \\
(0.174)\end{array}$ & $\begin{array}{l}-0.284 * \\
(0.149)\end{array}$ & $\begin{array}{l}-0.053 \\
(0.107)\end{array}$ & $\begin{array}{c}0.065 \\
(0.106)\end{array}$ & $\begin{array}{c}0.155 \\
(0.109)\end{array}$ & $\begin{array}{c}0.151 \\
(0.105)\end{array}$ & $\begin{array}{c}0.227 * * \\
(0.111)\end{array}$ & $\begin{array}{l}0.166^{*} \\
(0.088)\end{array}$ \\
\hline $\begin{array}{l}\text { Book-to-Market ratio } \\
\text { Capital Expenditure }\end{array}$ & $\begin{array}{c}-0.474 * * * \\
(0.146) \\
0.105 \\
(0.623)\end{array}$ & $\begin{array}{c}-0.427 * * * \\
(0.116) \\
0.325 \\
(0.514)\end{array}$ & $\begin{array}{c}-0.550 * * * \\
(0.095) \\
0.327 \\
(0.440)\end{array}$ & $\begin{array}{c}-0.655^{* * *} \\
(0.083) \\
0.283 \\
(0.358)\end{array}$ & $\begin{array}{c}-0.363 * * * \\
(0.055) \\
0.376 \\
(0.352)\end{array}$ & $\begin{array}{c}-0.338 * * * \\
(0.052) \\
0.577 * \\
(0.333)\end{array}$ & $\begin{array}{c}-0.310 * * * \\
(0.051) \\
0.481 \\
(0.328)\end{array}$ & $\begin{array}{c}-0.321 * * * \\
(0.052) \\
0.497 * \\
(0.294)\end{array}$ & $\begin{array}{c}-0.325 * * * \\
(0.049) \\
0.457 \\
(0.290)\end{array}$ & $\begin{array}{c}-0.331 * * * \\
(0.047) \\
0.348 \\
(0.303)\end{array}$ & $\begin{array}{c}-0.332 * * * \\
(0.046) \\
0.381 \\
(0.290)\end{array}$ & $\begin{array}{c}-0.340 * * * \\
(0.045) \\
0.592 * * \\
(0.295)\end{array}$ \\
\hline Constant & $\begin{array}{l}-0.634 \\
(1.207)\end{array}$ & $\begin{array}{l}-0.154 \\
(0.915)\end{array}$ & $\begin{array}{l}1.714 * * \\
(0.705)\end{array}$ & $\begin{array}{c}2.877 * * * \\
(0.572)\end{array}$ & $\begin{array}{c}2.379 * * * \\
(0.539)\end{array}$ & $\begin{array}{c}2.004 * * * \\
(0.486)\end{array}$ & $\begin{array}{c}1.847 * * * \\
(0.478)\end{array}$ & $\begin{array}{c}1.687 * * * \\
(0.449)\end{array}$ & $\begin{array}{c}1.816^{* * * *} \\
(0.426)\end{array}$ & $\begin{array}{c}2.164 * * * \\
(0.396)\end{array}$ & $\begin{array}{c}1.779 * * * \\
(0.422)\end{array}$ & $\begin{array}{c}1.997 * * * \\
(0.374)\end{array}$ \\
\hline $\begin{array}{l}\text { Firm Fixed Effects } \\
\text { Year Fixed Effects }\end{array}$ & $\begin{array}{l}\text { Yes } \\
\text { Yes }\end{array}$ & $\begin{array}{l}\text { Yes } \\
\text { Yes }\end{array}$ & $\begin{array}{l}\text { Yes } \\
\text { Yes }\end{array}$ & $\begin{array}{l}\text { Yes } \\
\text { Yes }\end{array}$ & $\begin{array}{l}\text { Yes } \\
\text { Yes }\end{array}$ & $\begin{array}{l}\text { Yes } \\
\text { Yes }\end{array}$ & $\begin{array}{l}\text { Yes } \\
\text { Yes }\end{array}$ & $\begin{array}{l}\text { Yes } \\
\text { Yes }\end{array}$ & $\begin{array}{l}\text { Yes } \\
\text { Yes }\end{array}$ & $\begin{array}{l}\text { Yes } \\
\text { Yes }\end{array}$ & $\begin{array}{l}\text { Yes } \\
\text { Yes }\end{array}$ & $\begin{array}{l}\text { Yes } \\
\text { Yes }\end{array}$ \\
\hline $\begin{array}{l}\text { Observations } \\
\text { R-squared } \\
\text { Number of Unique Firms }\end{array}$ & $\begin{array}{c}1,065 \\
0.170 \\
295 \\
\end{array}$ & $\begin{array}{c}1,374 \\
0.166 \\
318 \\
\end{array}$ & $\begin{array}{c}1,714 \\
0.171 \\
352 \\
\end{array}$ & $\begin{array}{c}2,054 \\
0.258 \\
354 \\
\end{array}$ & $\begin{array}{c}2,382 \\
0.251 \\
355 \\
\end{array}$ & $\begin{array}{c}2,727 \\
0.227 \\
355 \\
\end{array}$ & $\begin{array}{c}3,065 \\
0.304 \\
355 \\
\end{array}$ & $\begin{array}{c}3,404 \\
0.302 \\
355 \\
\end{array}$ & $\begin{array}{c}3,737 \\
0.296 \\
356 \\
\end{array}$ & $\begin{array}{c}4,056 \\
0.279 \\
356 \\
\end{array}$ & $\begin{array}{c}4,361 \\
0.276 \\
356 \\
\end{array}$ & $\begin{array}{c}4,644 \\
0.273 \\
356 \\
\end{array}$ \\
\hline
\end{tabular}


Table 3 - Panel B: OLS regression analysis - Impact on mean analysts' recommendations, adding years (Full Sample)

\begin{tabular}{|c|c|c|c|c|c|c|c|c|c|c|c|c|}
\hline & \multicolumn{12}{|c|}{ Time Period } \\
\hline Dependent Variable & $\begin{array}{l}\text { 1993-96 } \\
\text { meanrec }\end{array}$ & $\begin{array}{l}\text { 1993-97 } \\
\text { meanrec }\end{array}$ & $\begin{array}{l}1993-98 \\
\text { meanrec }\end{array}$ & $\begin{array}{l}\text { 1993-99 } \\
\text { meanrec }\end{array}$ & $\begin{array}{l}\text { 1993-00 } \\
\text { meanrec }\end{array}$ & $\begin{array}{l}\text { 1993-01 } \\
\text { meanrec }\end{array}$ & $\begin{array}{l}\text { 1993-02 } \\
\text { meanrec }\end{array}$ & $\begin{array}{l}\text { 1993-03 } \\
\text { meanrec }\end{array}$ & $\begin{array}{l}\text { 1993-04 } \\
\text { meanrec }\end{array}$ & $\begin{array}{l}\text { 1993-05 } \\
\text { meanrec }\end{array}$ & $\begin{array}{l}\text { 1993-06 } \\
\text { meanrec }\end{array}$ & $\begin{array}{l}\text { 1993-07 } \\
\text { meanrec }\end{array}$ \\
\hline Total CSR Strengths & $\begin{array}{c}-0.083 * * * * \\
0.022\end{array}$ & $\begin{array}{c}-0.078 * * * \\
0.021\end{array}$ & $\begin{array}{c}-0.065 * * * \\
0.018\end{array}$ & $\begin{array}{c}-\mathbf{0 . 0 5 1} * * * * \\
0.017\end{array}$ & $\begin{array}{c}-0.044 * * * \\
0.016\end{array}$ & $\begin{array}{c}-0.027 * * \\
0.013\end{array}$ & $\begin{array}{c}-\mathbf{0 . 0 2 6} * * \\
0.013\end{array}$ & $\begin{array}{l}0.001 \\
0.009\end{array}$ & $\begin{array}{l}0.002 \\
0.008 \\
\end{array}$ & $\begin{array}{l}\mathbf{0 . 0 0 4} \\
\mathbf{0 . 0 0 7}\end{array}$ & $\begin{array}{l}0.005 \\
0.006\end{array}$ & $\begin{array}{l}0.004 \\
0.006\end{array}$ \\
\hline Total CSR Concerns & $\begin{array}{c}-0.004 \\
0.018\end{array}$ & $\begin{array}{c}-0.004 \\
0.015\end{array}$ & $\begin{array}{l}0.002 \\
0.014\end{array}$ & $\begin{array}{l}0.001 \\
0.013\end{array}$ & $\begin{array}{l}0.003 \\
0.012\end{array}$ & $\begin{array}{l}0.007 \\
0.011\end{array}$ & $\begin{array}{l}0.005 \\
0.011\end{array}$ & $\begin{array}{l}0.001 \\
0.010\end{array}$ & $\begin{array}{c}-0.011 \\
0.008\end{array}$ & $\begin{array}{c}-0.013^{*} \\
0.007\end{array}$ & $\begin{array}{c}-0.012^{*} \\
0.007\end{array}$ & $\begin{array}{c}-0.010 \\
0.007\end{array}$ \\
\hline Number of Analysts & $\begin{array}{l}0.002 \\
0.005\end{array}$ & $\begin{array}{c}-0.001 \\
0.004\end{array}$ & $\begin{array}{l}0.001 \\
0.003\end{array}$ & $\begin{array}{l}0.001 \\
0.003\end{array}$ & $\begin{array}{c}-0.003 \\
0.003\end{array}$ & $\begin{array}{c}-0.004 * \\
0.002\end{array}$ & $\begin{array}{c}-0.006^{* * *} * \\
0.002\end{array}$ & $\begin{array}{c}-0.005^{* *} \\
0.002\end{array}$ & $\begin{array}{c}-0.005^{* * *} * \\
0.002\end{array}$ & $\begin{array}{c}-0.007 * * * \\
0.002\end{array}$ & $\begin{array}{c}-0.006 * * * \\
0.002\end{array}$ & $\begin{array}{c}-0.008 * * * \\
0.001\end{array}$ \\
\hline Mean House size & 0.000 & 0.000 & 0.000 & 0.000 & 0.000 & 0.000 & $-0.000 *$ & $-0.000 * *$ & $-0.000 *$ & $-0.000 * *$ & $-0.000 * * *$ & $-0.000 * * *$ \\
\hline Long Term Forecast Error & $\begin{array}{c}-0.224 \\
0.789\end{array}$ & $\begin{array}{c}-0.089 \\
0.767\end{array}$ & $\begin{array}{l}0.431 \\
0.658\end{array}$ & $\begin{array}{l}0.330 \\
0.605\end{array}$ & $\begin{array}{l}0.441 \\
0.388\end{array}$ & $\begin{array}{c}0.762 * * \\
0.349\end{array}$ & $\begin{array}{l}0.340 \\
0.331\end{array}$ & $\begin{array}{l}0.405 \\
0.308\end{array}$ & $\begin{array}{l}0.138 \\
0.227\end{array}$ & $\begin{array}{c}-0.029 \\
0.199\end{array}$ & $\begin{array}{l}-0.022 \\
0.155\end{array}$ & $\begin{array}{r}-0.017 \\
0139\end{array}$ \\
\hline Market Value (Size) & $\begin{array}{c}0.320 * * * \\
0.066\end{array}$ & $\begin{array}{c}0.239 * * * \\
0.052\end{array}$ & $\begin{array}{c}0.121 * * * \\
0.043\end{array}$ & $\begin{array}{l}0.048 \\
0.035\end{array}$ & $\begin{array}{c}0.091 * * * \\
0.031\end{array}$ & $\begin{array}{c}0.113 * * * \\
0.030\end{array}$ & $\begin{array}{c}0.152 * * * \\
0.027\end{array}$ & $\begin{array}{c}0.162 * * * \\
0.024\end{array}$ & $\begin{array}{c}0.167 * * * \\
0.022\end{array}$ & $\begin{array}{c}0.153 * * * \\
0.020\end{array}$ & $\begin{array}{c}0.163 * * * \\
0.018\end{array}$ & $\begin{array}{c}0.152 * * * \\
0.016\end{array}$ \\
\hline Market Adjusted Return & $\begin{array}{c}0.176 * * * \\
0.037\end{array}$ & $\begin{array}{c}0.184 * * * \\
0.032\end{array}$ & $\begin{array}{c}0.183 * * * \\
0.029\end{array}$ & $\begin{array}{c}0.131 * * * \\
0.021\end{array}$ & $\begin{array}{c}0.153 * * * \\
0.017\end{array}$ & $\begin{array}{c}0.156^{* * *} * \\
0.016\end{array}$ & $\begin{array}{c}0.164 * * * \\
0.015\end{array}$ & $\begin{array}{c}0.164 * * * \\
0.016\end{array}$ & $\begin{array}{c}0.146 * * * \\
0.013\end{array}$ & $\begin{array}{c}0.119 * * * \\
0.012\end{array}$ & $\begin{array}{c}0.108 * * * \\
0.011\end{array}$ & $\begin{array}{c}0.111 * * * \\
0.010\end{array}$ \\
\hline Intangibles & $\begin{array}{l}0.128 \\
0.227\end{array}$ & $\begin{array}{l}0.192 \\
0.173\end{array}$ & $\begin{array}{l}0.238 \\
0.152\end{array}$ & $\begin{array}{c}0.265^{*} \\
0.141\end{array}$ & $\begin{array}{l}0.168 \\
0.133\end{array}$ & $\begin{array}{l}0.097 \\
0.122\end{array}$ & $\begin{array}{l}0.101 \\
0.104\end{array}$ & $\begin{array}{l}0.157 \\
0.100\end{array}$ & $\begin{array}{c}0.199 * * \\
0.090\end{array}$ & $\begin{array}{c}0.186 * * \\
0.081\end{array}$ & $\begin{array}{c}0.147 * * \\
0.073\end{array}$ & $\begin{array}{c}0.212 * * * \\
0.065\end{array}$ \\
\hline Return on Assets & $\begin{array}{l}0.455 \\
0.370\end{array}$ & $\begin{array}{l}0.505 \\
0.326\end{array}$ & $\begin{array}{c}0.608 * * \\
0.280\end{array}$ & $\begin{array}{c}0.933 * * * \\
0.284\end{array}$ & $\begin{array}{c}1.152 * * * \\
0.241\end{array}$ & $\begin{array}{c}0.850 * * * \\
0.205\end{array}$ & $\begin{array}{c}0.497 * * * \\
0.173\end{array}$ & $\begin{array}{c}0.380 * * \\
0.166\end{array}$ & $\begin{array}{c}0.397 * * * \\
0.138\end{array}$ & $\begin{array}{c}0.377 * * * \\
0.120\end{array}$ & $\begin{array}{c}0.271 * * \\
0.108\end{array}$ & $\begin{array}{c}0.282 * * * \\
0.103\end{array}$ \\
\hline Earnings-to-price ratio & $\begin{array}{l}0.142 \\
0.188\end{array}$ & $\begin{array}{l}0.160 \\
0.180\end{array}$ & $\begin{array}{l}0.041 \\
0.166\end{array}$ & $\begin{array}{l}0.066 \\
0.155\end{array}$ & $\begin{array}{c}-0.206 \\
0.133\end{array}$ & $\begin{array}{c}-0.191 \\
0.117\end{array}$ & $\begin{array}{l}0.123 \\
0.079\end{array}$ & $\begin{array}{c}0.129 * * \\
0.065\end{array}$ & $\begin{array}{c}0.152 * * \\
0.060\end{array}$ & $\begin{array}{c}0.168 * * * \\
0.059\end{array}$ & $\begin{array}{c}0.239 * * * \\
0.059\end{array}$ & $\begin{array}{c}0.195^{* * *} * \\
0.046\end{array}$ \\
\hline Book-to-Market ratio & $\begin{array}{c}-0.431 * * * \\
0.106\end{array}$ & $\begin{array}{c}-0.439 * * * \\
0.093\end{array}$ & $\begin{array}{c}-0.546^{* * * *} \\
0.081\end{array}$ & $\begin{array}{c}-0.644 * * * \\
0.073\end{array}$ & $\begin{array}{c}-0.391 * * * \\
0.051\end{array}$ & $\begin{array}{c}-0.378 * * * \\
0.048\end{array}$ & $\begin{array}{c}-0.313 * * * \\
0.043\end{array}$ & $\begin{array}{c}-0.310 * * * \\
0.041\end{array}$ & $\begin{array}{c}-0.308 * * * \\
0.037\end{array}$ & $\begin{array}{c}-0.348 * * * \\
0.036\end{array}$ & $\begin{array}{c}-0.337 * * * \\
0.033\end{array}$ & $\begin{array}{c}-0.357 * * * \\
0.029\end{array}$ \\
\hline Capital Expenditure & $\begin{array}{c}-0.117 \\
0.477\end{array}$ & $\begin{array}{l}0.246 \\
0.407\end{array}$ & $\begin{array}{l}0.231 \\
0.361\end{array}$ & $\begin{array}{l}0.310 \\
0.310\end{array}$ & $\begin{array}{l}0.327 \\
0.301\end{array}$ & $\begin{array}{c}0.485^{*} \\
0.282\end{array}$ & $\begin{array}{c}0.488^{*} \\
0.270\end{array}$ & $\begin{array}{l}0.364 \\
0.245 \\
\end{array}$ & $\begin{array}{l}0.327 \\
0.224 \\
\end{array}$ & $\begin{array}{l}0.234 \\
0.209 \\
\end{array}$ & $\begin{array}{l}0.310 \\
0.191\end{array}$ & $\begin{array}{l}0.262 \\
0.173 \\
\end{array}$ \\
\hline $\begin{array}{l}\text { Constant } \\
\text { Firm Fixed Effects } \\
\text { Year Fixed Effects }\end{array}$ & $\begin{array}{c}-0.929 \\
0.982 \\
\text { Yes } \\
\text { Yes }\end{array}$ & $\begin{array}{c}0.313 \\
0.767 \\
\text { Yes } \\
\text { Yes }\end{array}$ & $\begin{array}{c}2.070 * * * \\
0.657 \\
\text { Yes } \\
\text { Yes }\end{array}$ & $\begin{array}{c}3.380 * * * \\
0.544 \\
\text { Yes } \\
\text { Yes }\end{array}$ & $\begin{array}{c}2.389 * * * \\
0.460 \\
\text { Yes } \\
\text { Yes }\end{array}$ & $\begin{array}{c}2.122 * * * \\
0.436 \\
\text { Yes } \\
\text { Yes }\end{array}$ & $\begin{array}{c}1.629 * * * \\
0.410 \\
\text { Yes } \\
\text { Yes }\end{array}$ & $\begin{array}{c}1.185 * * * \\
0.365 \\
\text { Yes } \\
\text { Yes }\end{array}$ & $\begin{array}{c}1.514 * * * \\
0.302 \\
\text { Yes } \\
\text { Yes }\end{array}$ & $\begin{array}{c}1.777 * * * \\
0.286 \\
\text { Yes } \\
\text { Yes }\end{array}$ & $\begin{array}{c}1.661 * * * \\
0.249 \\
\text { Yes } \\
\text { Yes }\end{array}$ & $\begin{array}{c}1.846^{* * *} \\
0.224 \\
\text { Yes } \\
\text { Yes }\end{array}$ \\
\hline $\begin{array}{l}\text { Observations } \\
\text { R-squared } \\
\text { Number of Unique Firms }\end{array}$ & $\begin{array}{c}1,467 \\
0.189 \\
427 \\
\end{array}$ & $\begin{array}{c}1,855 \\
0.174 \\
460 \\
\end{array}$ & $\begin{array}{c}2,260 \\
0.176 \\
509 \\
\end{array}$ & $\begin{array}{c}2,682 \\
0.246 \\
560 \\
\end{array}$ & $\begin{array}{c}3,132 \\
0.247 \\
617 \\
\end{array}$ & $\begin{array}{l}3,982 \\
0.235 \\
1,014 \\
\end{array}$ & $\begin{array}{l}4,871 \\
0.351 \\
1,149 \\
\end{array}$ & $\begin{array}{l}6,967 \\
0.331 \\
2,320 \\
\end{array}$ & $\begin{array}{l}9,194 \\
0.274 \\
2,725 \\
\end{array}$ & $\begin{array}{c}11,496 \\
0.224 \\
3,040 \\
\end{array}$ & $\begin{array}{c}13,753 \\
0.2 \\
3,291 \\
\end{array}$ & $\begin{array}{c}16,064 \\
0.181 \\
3,580 \\
\end{array}$ \\
\hline
\end{tabular}


Table 4, Panel A: OLS regression analysis - Impact on mean analysts' recommendations for top two quartiles of analyst experience

\begin{tabular}{|c|c|c|c|c|c|c|c|c|c|c|c|c|}
\hline \multirow[b]{2}{*}{ Dependent Variable } & \multicolumn{12}{|c|}{ Time Period } \\
\hline & $\begin{array}{l}\text { 1993-96 } \\
\text { meanrec }\end{array}$ & $\begin{array}{l}\text { 1993-97 } \\
\text { meanrec }\end{array}$ & $\begin{array}{l}1993-98 \\
\text { meanrec }\end{array}$ & $\begin{array}{l}\text { 1993-99 } \\
\text { meanrec }\end{array}$ & $\begin{array}{l}\text { 1993-00 } \\
\text { meanrec }\end{array}$ & $\begin{array}{l}\text { 1993-01 } \\
\text { meanrec }\end{array}$ & $\begin{array}{l}\text { 1993-02 } \\
\text { meanrec }\end{array}$ & $\begin{array}{l}\text { 1993-03 } \\
\text { meanrec }\end{array}$ & $\begin{array}{l}\text { 1993-04 } \\
\text { meanrec }\end{array}$ & $\begin{array}{l}\text { 1993-05 } \\
\text { meanrec }\end{array}$ & $\begin{array}{l}\text { 1993-06 } \\
\text { meanrec }\end{array}$ & $\begin{array}{l}\text { 1993-07 } \\
\text { meanrec }\end{array}$ \\
\hline Total CSR Strengths & $\begin{array}{c}-\mathbf{0 . 0 7 1} * * * \\
0.024 \\
\end{array}$ & $\begin{array}{c}-\mathbf{0 . 0 6 7} * * * \\
0.022 \\
\end{array}$ & $\begin{array}{c}-\mathbf{0 . 0 5 5} * * * \\
0.019 \\
\end{array}$ & $\begin{array}{c}-0.047 * * * \\
0.018 \\
\end{array}$ & $\begin{array}{c}-\mathbf{- 0 . 0 4 0} * * \\
0.016\end{array}$ & $\begin{array}{c}-\mathbf{0 . 0 1 7} \\
\mathbf{0 . 0 1 3}\end{array}$ & $\begin{array}{c}-\mathbf{- 0 . 0 1 2} \\
0.013\end{array}$ & $\begin{array}{l}\mathbf{0 . 0 1 1} \\
\mathbf{0 . 0 0 9}\end{array}$ & $\begin{array}{l}0.013 \\
0.008\end{array}$ & $\begin{array}{c}0.015 * * \\
0.007\end{array}$ & $\begin{array}{c}0.015 * * \\
0.006\end{array}$ & $\begin{array}{c}0.014 * * \\
0.006\end{array}$ \\
\hline Total CSR Concerns & $\begin{array}{c}-0.029 \\
0.020\end{array}$ & $\begin{array}{c}-0.018 \\
0.017\end{array}$ & $\begin{array}{c}-0.011 \\
0.015\end{array}$ & $\begin{array}{c}-0.012 \\
0.014\end{array}$ & $\begin{array}{c}-0.010 \\
0.013\end{array}$ & $\begin{array}{c}-0.005 \\
0.011\end{array}$ & $\begin{array}{c}-0.003 \\
0.012\end{array}$ & $\begin{array}{c}-0.003 \\
0.010\end{array}$ & $\begin{array}{c}-0.015^{*} \\
0.009\end{array}$ & $\begin{array}{c}-0.017 * * \\
0.008\end{array}$ & $\begin{array}{c}-0.016^{* *} \\
0.007\end{array}$ & $\begin{array}{c}-0.017 * * \\
0.007\end{array}$ \\
\hline Number of Analysts & $\begin{array}{l}0.005 \\
0.005\end{array}$ & $\begin{array}{l}0.000 \\
0.004\end{array}$ & $\begin{array}{l}0.001 \\
0.004\end{array}$ & $\begin{array}{c}-0.001 \\
0.003\end{array}$ & $\begin{array}{c}-0.004 \\
0.003\end{array}$ & $\begin{array}{c}-0.005^{* *} \\
0.003\end{array}$ & $\begin{array}{c}-0.008 * * * \\
0.002\end{array}$ & $\begin{array}{c}-0.005^{* *} \\
0.002\end{array}$ & $\begin{array}{c}-0.005^{* *} \\
0.002\end{array}$ & $\begin{array}{c}-0.006 * * * \\
0.002\end{array}$ & $\begin{array}{c}-0.006 * * * \\
0.002\end{array}$ & $\begin{array}{c}-0.007 * * * \\
0.002\end{array}$ \\
\hline Mean House size & $\begin{array}{l}0.000 \\
0.001\end{array}$ & $\begin{array}{l}0.000 \\
0.000\end{array}$ & $\begin{array}{l}0.000 \\
0.000\end{array}$ & $\begin{array}{l}0.000 \\
0.000\end{array}$ & $\begin{array}{l}0.000 \\
0.000\end{array}$ & $\begin{array}{c}-0.000 * \\
0.000\end{array}$ & $\begin{array}{l}0.000 \\
0.000\end{array}$ & $\begin{array}{c}-0.000 * \\
0.000\end{array}$ & $\begin{array}{c}-0.000 * \\
0.000\end{array}$ & $\begin{array}{c}-0.000 * * \\
0.000\end{array}$ & $\begin{array}{c}-0.000 * * * \\
0.000\end{array}$ & $\begin{array}{c}-0.000 * * * \\
0.000\end{array}$ \\
\hline Long Term Forecast Error & $\begin{array}{l}1.006 \\
1.318\end{array}$ & $\begin{array}{l}0.171 \\
1.063\end{array}$ & $\begin{array}{l}0.603 \\
0.777\end{array}$ & $\begin{array}{l}0.223 \\
0.794\end{array}$ & $\begin{array}{l}0.358 \\
0.384\end{array}$ & $\begin{array}{c}0.847 * * \\
0.350\end{array}$ & $\begin{array}{l}0.272 \\
0.354\end{array}$ & $\begin{array}{l}0.336 \\
0.328\end{array}$ & $\begin{array}{l}0.284 \\
0.241\end{array}$ & $\begin{array}{l}0.024 \\
0.215\end{array}$ & $\begin{array}{c}-0.006 \\
0.170\end{array}$ & $\begin{array}{l}0.028 \\
0.155\end{array}$ \\
\hline Market Value (Size) & $\begin{array}{c}0.378 * * * \\
0.070\end{array}$ & $\begin{array}{c}0.279 * * * \\
0.055\end{array}$ & $\begin{array}{c}0.134 * * * \\
0.045\end{array}$ & $\begin{array}{c}0.069^{*} \\
0.037\end{array}$ & $\begin{array}{c}0.114 * * * \\
0.034\end{array}$ & $\begin{array}{c}0.136 * * * \\
0.032\end{array}$ & $\begin{array}{c}0.177 * * * \\
0.028\end{array}$ & $\begin{array}{c}0.184 * * * \\
0.025\end{array}$ & $\begin{array}{c}0.178 * * * \\
0.023\end{array}$ & $\begin{array}{c}0.163 * * * \\
0.022\end{array}$ & $\begin{array}{c}0.172 * * * \\
0.020\end{array}$ & $\begin{array}{c}0.159 * * * \\
0.018\end{array}$ \\
\hline Market Adjusted Return & $\begin{array}{c}0.150 * * * \\
0.042\end{array}$ & $\begin{array}{c}0.175^{* * * *} \\
0.036\end{array}$ & $\begin{array}{c}0.175^{* * * *} \\
0.033\end{array}$ & $\begin{array}{c}0.124 * * * \\
0.023\end{array}$ & $\begin{array}{c}0.156^{* * * *} \\
0.018\end{array}$ & $\begin{array}{c}0.157 * * * \\
0.018\end{array}$ & $\begin{array}{c}0.164 * * * \\
0.016\end{array}$ & $\begin{array}{c}0.160 * * * \\
0.016\end{array}$ & $\begin{array}{c}0.145^{* * * *} \\
0.014\end{array}$ & $\begin{array}{c}0.121 * * * \\
0.012\end{array}$ & $\begin{array}{c}0.112 * * * \\
0.012\end{array}$ & $\begin{array}{c}0.116^{* * *} \\
0.012\end{array}$ \\
\hline Intangibles & $\begin{array}{l}0.056 \\
0.263\end{array}$ & $\begin{array}{l}0.186 \\
0.186\end{array}$ & $\begin{array}{c}0.309^{*} \\
0.170\end{array}$ & $\begin{array}{c}0.333^{* *} \\
0.161\end{array}$ & $\begin{array}{c}0.260^{*} \\
0.149\end{array}$ & $\begin{array}{l}0.161 \\
0.137\end{array}$ & $\begin{array}{l}0.117 \\
0.113\end{array}$ & $\begin{array}{l}0.163 \\
0.109\end{array}$ & $\begin{array}{c}0.217 * * \\
0.100\end{array}$ & $\begin{array}{c}0.250 * * * \\
0.089\end{array}$ & $\begin{array}{c}0.212^{* *} \\
0.083\end{array}$ & $\begin{array}{c}0.272 * * * \\
0.078\end{array}$ \\
\hline Return on Assets & $\begin{array}{l}0.126 \\
0.431\end{array}$ & $\begin{array}{l}0.255 \\
0.366\end{array}$ & $\begin{array}{l}0.447 \\
0.288\end{array}$ & $\begin{array}{c}0.630 * * \\
0.280\end{array}$ & $\begin{array}{c}0.967 * * * \\
0.238\end{array}$ & $\begin{array}{c}0.673 * * * \\
0.209\end{array}$ & $\begin{array}{c}0.297 * \\
0.172\end{array}$ & $\begin{array}{l}0.175 \\
0.165\end{array}$ & $\begin{array}{l}0.204 \\
0.145\end{array}$ & $\begin{array}{c}0.244^{*} \\
0.132\end{array}$ & $\begin{array}{c}0.221^{*} \\
0.123\end{array}$ & $\begin{array}{c}0.204 * \\
0.113\end{array}$ \\
\hline Earnings-to-price ratio & $\begin{array}{c}-0.086 \\
0.309\end{array}$ & $\begin{array}{c}-0.052 \\
0.254\end{array}$ & $\begin{array}{c}-0.068 \\
0.225\end{array}$ & $\begin{array}{l}0.095 \\
0.204\end{array}$ & $\begin{array}{c}-0.159 \\
0.162\end{array}$ & $\begin{array}{c}-0.136 \\
0.139\end{array}$ & $\begin{array}{c}0.142 * \\
0.082\end{array}$ & $\begin{array}{c}0.147 * * \\
0.069\end{array}$ & $\begin{array}{c}0.188 * * * \\
0.062\end{array}$ & $\begin{array}{c}0.183 * * * \\
0.060\end{array}$ & $\begin{array}{c}0.250 * * * \\
0.063\end{array}$ & $\begin{array}{c}0.200 * * * \\
0.051\end{array}$ \\
\hline Book-to-Market ratio & $\begin{array}{c}-0.531 * * * \\
0.132\end{array}$ & $\begin{array}{c}-0.556^{* * *} \\
0.108\end{array}$ & $\begin{array}{c}-0.626 * * * \\
0.087\end{array}$ & $\begin{array}{c}-0.691 * * * \\
0.078\end{array}$ & $\begin{array}{c}-0.375^{* * *} \\
0.055\end{array}$ & $\begin{array}{c}-0.379 * * * \\
0.052\end{array}$ & $\begin{array}{c}-0.309 * * * \\
0.039\end{array}$ & $\begin{array}{c}-0.311^{* * *} \\
0.037\end{array}$ & $\begin{array}{c}-0.309 * * * \\
0.036\end{array}$ & $\begin{array}{c}-0.339 * * * \\
0.036\end{array}$ & $\begin{array}{c}-0.331 * * * \\
0.034\end{array}$ & $\begin{array}{c}-0.349 * * * \\
0.031\end{array}$ \\
\hline Capital Expenditure & $\begin{array}{c}-0.206 \\
0.641\end{array}$ & $\begin{array}{l}0.149 \\
0.495\end{array}$ & $\begin{array}{l}0.269 \\
0.432\end{array}$ & $\begin{array}{l}0.317 \\
0.371\end{array}$ & $\begin{array}{l}0.418 \\
0.356\end{array}$ & $\begin{array}{l}0.505 \\
0.321\end{array}$ & $\begin{array}{c}0.561 * \\
0.306\end{array}$ & $\begin{array}{c}0.505^{*} \\
0.266\end{array}$ & $\begin{array}{l}0.290 \\
0.242\end{array}$ & $\begin{array}{l}0.215 \\
0.233\end{array}$ & $\begin{array}{l}0.296 \\
0.209\end{array}$ & $\begin{array}{c}0.345^{*} \\
0.195\end{array}$ \\
\hline Constant & $\begin{array}{c}-1.776^{*} \\
1.043\end{array}$ & $\begin{array}{c}-0.389 \\
0.850\end{array}$ & $\begin{array}{c}1.890 * * * \\
0.686\end{array}$ & $\begin{array}{c}2.881 * * * \\
0.556\end{array}$ & $\begin{array}{c}2.140^{* * * *} \\
0.534\end{array}$ & $\begin{array}{c}1.838 * * * \\
0.479\end{array}$ & $\begin{array}{c}1.235 * * * \\
0.429\end{array}$ & $\begin{array}{c}0.809 * * \\
0.374\end{array}$ & $\begin{array}{c}1.351^{* * * *} \\
0.323\end{array}$ & $\begin{array}{c}1.191 * * * \\
0.330\end{array}$ & $\begin{array}{c}1.486 * * * \\
0.287\end{array}$ & $\begin{array}{c}1.655^{* * *} * \\
0.260\end{array}$ \\
\hline $\begin{array}{l}\text { Firm Fixed Effects } \\
\text { Year Fixed Effects }\end{array}$ & $\begin{array}{l}\text { Yes } \\
\text { Yes }\end{array}$ & $\begin{array}{l}\text { Yes } \\
\text { Yes }\end{array}$ & $\begin{array}{l}\text { Yes } \\
\text { Yes }\end{array}$ & $\begin{array}{l}\text { Yes } \\
\text { Yes }\end{array}$ & $\begin{array}{l}\text { Yes } \\
\text { Yes }\end{array}$ & $\begin{array}{l}\text { Yes } \\
\text { Yes }\end{array}$ & $\begin{array}{l}\text { Yes } \\
\text { Yes }\end{array}$ & $\begin{array}{l}\text { Yes } \\
\text { Yes }\end{array}$ & $\begin{array}{l}\text { Yes } \\
\text { Yes }\end{array}$ & $\begin{array}{l}\text { Yes } \\
\text { Yes }\end{array}$ & $\begin{array}{l}\text { Yes } \\
\text { Yes }\end{array}$ & $\begin{array}{l}\text { Yes } \\
\text { Yes }\end{array}$ \\
\hline $\begin{array}{l}\text { Observations } \\
\text { R-squared } \\
\text { Number of Unique Firms }\end{array}$ & $\begin{array}{c}1,034 \\
0.22 \\
289\end{array}$ & $\begin{array}{c}1,336 \\
0.209 \\
310\end{array}$ & $\begin{array}{c}1,669 \\
0.202 \\
352\end{array}$ & $\begin{array}{c}2,032 \\
0.276 \\
398\end{array}$ & $\begin{array}{c}2,420 \\
0.273 \\
445\end{array}$ & $\begin{array}{c}3,133 \\
0.261 \\
768\end{array}$ & $\begin{array}{c}3,896 \\
0.395 \\
877\end{array}$ & $\begin{array}{l}5,393 \\
0.372 \\
1,583\end{array}$ & $\begin{array}{l}6,861 \\
0.319 \\
1,711\end{array}$ & $\begin{array}{l}8,304 \\
0.272 \\
1,809\end{array}$ & $\begin{array}{c}9,673 \\
0.25 \\
1,866\end{array}$ & $\begin{array}{c}10,998 \\
0.228 \\
1,932\end{array}$ \\
\hline
\end{tabular}


Table 4, Panel B: OLS regression analysis - Impact on mean analysts' recommendations for bottom two quartiles of analyst experience

\begin{tabular}{|c|c|c|c|c|c|c|c|c|c|c|c|c|}
\hline \multirow[b]{2}{*}{ Dependent Variable } & \multicolumn{12}{|c|}{ Time Period } \\
\hline & $\begin{array}{l}\text { 1993-96 } \\
\text { meanrec }\end{array}$ & $\begin{array}{l}\text { 1993-97 } \\
\text { meanrec }\end{array}$ & $\begin{array}{l}1993-98 \\
\text { meanrec }\end{array}$ & $\begin{array}{l}\text { 1993-99 } \\
\text { meanrec }\end{array}$ & $\begin{array}{l}\text { 1993-00 } \\
\text { meanrec }\end{array}$ & $\begin{array}{l}\text { 1993-01 } \\
\text { meanrec }\end{array}$ & $\begin{array}{l}\text { 1993-02 } \\
\text { meanrec }\end{array}$ & $\begin{array}{l}\text { 1993-03 } \\
\text { meanrec }\end{array}$ & $\begin{array}{l}\text { 1993-04 } \\
\text { meanrec }\end{array}$ & $\begin{array}{l}1993-05 \\
\text { meanrec }\end{array}$ & $\begin{array}{l}\text { 1993-06 } \\
\text { meanrec }\end{array}$ & $\begin{array}{l}\text { 1993-07 } \\
\text { meanrec }\end{array}$ \\
\hline Total CSR Strengths & $\begin{array}{c}-0.100 * * \\
0.050\end{array}$ & $\begin{array}{c}-0.119 * * \\
0.052\end{array}$ & $\begin{array}{c}-\mathbf{- 0 . 1 0 0} * \\
0.053\end{array}$ & $\begin{array}{c}-0.060 \\
0.051\end{array}$ & $\begin{array}{c}-\mathbf{- 0 . 0 5 3} \\
0.050\end{array}$ & $\begin{array}{c}-0.060 \\
0.041\end{array}$ & $\begin{array}{c}-0.080 * * \\
0.040\end{array}$ & $\begin{array}{c}-\mathbf{- 0 . 0 4 3} \\
0.031\end{array}$ & $\begin{array}{c}-0.051 * \\
0.029\end{array}$ & $\begin{array}{c}-0.045 * * \\
0.022\end{array}$ & $\begin{array}{c}-\mathbf{- 0 . 0 3 4} * \\
0.018\end{array}$ & $\begin{array}{c}-0.036 * * \\
0.017\end{array}$ \\
\hline Total CSR Concerns & $\begin{array}{c}0.068^{*} \\
0.036\end{array}$ & $\begin{array}{l}0.046 \\
0.033\end{array}$ & $\begin{array}{l}0.056 \\
0.035\end{array}$ & $\begin{array}{c}0.060^{*} \\
0.035\end{array}$ & $\begin{array}{c}0.065^{* *} \\
0.032\end{array}$ & $\begin{array}{c}0.075^{* *} \\
0.029\end{array}$ & $\begin{array}{c}0.062 * \\
0.034\end{array}$ & $\begin{array}{l}0.047 \\
0.032\end{array}$ & $\begin{array}{l}0.027 \\
0.026\end{array}$ & $\begin{array}{l}0.020 \\
0.021\end{array}$ & $\begin{array}{l}0.021 \\
0.020\end{array}$ & $\begin{array}{c}0.032 * \\
0.018\end{array}$ \\
\hline Number of Analysts & $\begin{array}{c}-0.001 \\
0.010\end{array}$ & $\begin{array}{l}0.000 \\
0.009\end{array}$ & $\begin{array}{l}0.001 \\
0.008\end{array}$ & $\begin{array}{l}0.003 \\
0.008\end{array}$ & $\begin{array}{l}0.000 \\
0.007\end{array}$ & $\begin{array}{l}0.000 \\
0.006\end{array}$ & $\begin{array}{c}-0.004 \\
0.005\end{array}$ & $\begin{array}{c}-0.007 \\
0.005\end{array}$ & $\begin{array}{c}-0.010 * * \\
0.005\end{array}$ & $\begin{array}{c}-0.013 * * * \\
0.004\end{array}$ & $\begin{array}{c}-0.009 * * \\
0.004\end{array}$ & $\begin{array}{c}-0.011 * * * \\
0.003\end{array}$ \\
\hline Mean House size & $\begin{array}{c}-0.001 \\
0.001\end{array}$ & $\begin{array}{c}-0.001 * * \\
0.001\end{array}$ & $\begin{array}{l}0.000 \\
0.001\end{array}$ & $\begin{array}{l}0.000 \\
0.001\end{array}$ & $\begin{array}{l}0.000 \\
0.000\end{array}$ & $\begin{array}{l}0.000 \\
0.000\end{array}$ & $\begin{array}{l}0.000 \\
0.000\end{array}$ & $\begin{array}{l}0.000 \\
0.000\end{array}$ & $\begin{array}{l}0.000 \\
0.000\end{array}$ & $\begin{array}{l}0.000 \\
0.000\end{array}$ & $\begin{array}{l}0.000 \\
0.000\end{array}$ & $\begin{array}{l}0.000 \\
0.000\end{array}$ \\
\hline Long Term Forecast Error & $\begin{array}{c}-0.619 \\
1.004\end{array}$ & $\begin{array}{c}-0.377 \\
1.051\end{array}$ & $\begin{array}{l}0.131 \\
1.017\end{array}$ & $\begin{array}{l}0.251 \\
0.975\end{array}$ & $\begin{array}{l}0.520 \\
0.840\end{array}$ & $\begin{array}{l}0.561 \\
0.798\end{array}$ & $\begin{array}{l}0.567 \\
0.783\end{array}$ & $\begin{array}{l}0.698 \\
0.781\end{array}$ & $\begin{array}{c}-0.248 \\
0.533\end{array}$ & $\begin{array}{c}-0.145 \\
0.457\end{array}$ & $\begin{array}{c}-0.033 \\
0.352\end{array}$ & $\begin{array}{c}-0.078 \\
0.271\end{array}$ \\
\hline Market Value (Size) & $\begin{array}{l}0.227 \\
0.156\end{array}$ & $\begin{array}{l}0.140 \\
0.133\end{array}$ & $\begin{array}{l}0.085 \\
0.110\end{array}$ & $\begin{array}{c}-0.005 \\
0.077\end{array}$ & $\begin{array}{l}0.041 \\
0.064\end{array}$ & $\begin{array}{l}0.068 \\
0.060\end{array}$ & $\begin{array}{c}0.108^{*} \\
0.064\end{array}$ & $\begin{array}{c}0.131 * * \\
0.064\end{array}$ & $\begin{array}{c}0.197 * * * \\
0.056\end{array}$ & $\begin{array}{c}0.179 * * * \\
0.046\end{array}$ & $\begin{array}{c}0.175 * * * \\
0.039\end{array}$ & $\begin{array}{c}0.166^{* * *} \\
0.033\end{array}$ \\
\hline Market Adjusted Return & $\begin{array}{c}0.250 * * * \\
0.077\end{array}$ & $\begin{array}{c}0.216^{* * * *} \\
0.069\end{array}$ & $\begin{array}{c}0.210 * * * \\
0.066\end{array}$ & $\begin{array}{c}0.159 * * * \\
0.058\end{array}$ & $\begin{array}{c}0.135 * * * \\
0.044\end{array}$ & $\begin{array}{c}0.153 * * * \\
0.041\end{array}$ & $\begin{array}{c}0.158 * * * \\
0.041\end{array}$ & $\begin{array}{c}0.177 * * * \\
0.049\end{array}$ & $\begin{array}{c}0.147 * * * \\
0.034\end{array}$ & $\begin{array}{c}0.116^{* * * *} \\
0.029\end{array}$ & $\begin{array}{c}0.103 * * * \\
0.023\end{array}$ & $\begin{array}{c}0.103 * * * \\
0.021\end{array}$ \\
\hline Intangibles & $\begin{array}{l}0.044 \\
0.384\end{array}$ & $\begin{array}{l}0.080 \\
0.392\end{array}$ & $\begin{array}{c}-0.006 \\
0.328\end{array}$ & $\begin{array}{c}-0.030 \\
0.307\end{array}$ & $\begin{array}{c}-0.200 \\
0.298\end{array}$ & $\begin{array}{c}-0.167 \\
0.265\end{array}$ & $\begin{array}{l}0.063 \\
0.248\end{array}$ & $\begin{array}{l}0.227 \\
0.213\end{array}$ & $\begin{array}{l}0.147 \\
0.191\end{array}$ & $\begin{array}{c}-0.013 \\
0.171\end{array}$ & $\begin{array}{c}-0.049 \\
0.144\end{array}$ & $\begin{array}{l}0.054 \\
0.114\end{array}$ \\
\hline Return on Assets & $\begin{array}{l}1.115 \\
0.790\end{array}$ & $\begin{array}{c}1.160 * \\
0.682\end{array}$ & $\begin{array}{l}1.177 \\
0.717\end{array}$ & $\begin{array}{c}1.954 * * * \\
0.742\end{array}$ & $\begin{array}{c}1.789 * * * \\
0.663\end{array}$ & $\begin{array}{c}1.537 * * * \\
0.543\end{array}$ & $\begin{array}{c}1.375^{* * *} \\
0.473\end{array}$ & $\begin{array}{c}1.293 * * * \\
0.459\end{array}$ & $\begin{array}{c}1.141 * * * \\
0.331\end{array}$ & $\begin{array}{c}0.811^{* * * *} \\
0.262\end{array}$ & $\begin{array}{c}0.426^{*} \\
0.219\end{array}$ & $\begin{array}{c}0.418 * * \\
0.199\end{array}$ \\
\hline Earnings-to-price ratio & $\begin{array}{l}0.195 \\
0.273\end{array}$ & $\begin{array}{l}0.291 \\
0.282\end{array}$ & $\begin{array}{l}0.040 \\
0.277\end{array}$ & $\begin{array}{c}-0.153 \\
0.266\end{array}$ & $\begin{array}{c}-0.414 \\
0.251\end{array}$ & $\begin{array}{c}-0.391 \\
0.239\end{array}$ & $\begin{array}{c}-0.197 \\
0.218\end{array}$ & $\begin{array}{c}-0.134 \\
0.207\end{array}$ & $\begin{array}{c}-0.141 \\
0.208\end{array}$ & $\begin{array}{l}0.029 \\
0.180\end{array}$ & $\begin{array}{l}0.131 \\
0.162\end{array}$ & $\begin{array}{c}0.184 * \\
0.111\end{array}$ \\
\hline $\begin{array}{l}\text { Book-to-Market ratio } \\
\text { Capital Expenditure }\end{array}$ & $\begin{array}{l}-0.203 \\
0.171 \\
0.249 \\
0.704\end{array}$ & $\begin{array}{c}-0.148 \\
0.169 \\
0.706 \\
0.697\end{array}$ & $\begin{array}{c}-0.300^{*} \\
0.180 \\
0.382 \\
0.673\end{array}$ & $\begin{array}{c}-0.468 * * * \\
0.163 \\
0.412 \\
0.550\end{array}$ & $\begin{array}{c}-0.403 * * * \\
0.127 \\
0.192 \\
0.555\end{array}$ & $\begin{array}{c}-0.302 * * \\
0.131 \\
0.498 \\
0.551\end{array}$ & $\begin{array}{c}-0.277 * \\
0.161 \\
0.313 \\
0.526\end{array}$ & $\begin{array}{c}-0.278^{*} \\
0.160 \\
-0.196 \\
0.572\end{array}$ & $\begin{array}{c}-0.283 * * \\
0.118 \\
0.512 \\
0.535\end{array}$ & $\begin{array}{c}-0.361 * * * \\
0.106 \\
0.418 \\
0.450\end{array}$ & $\begin{array}{c}-0.340 * * * \\
0.090 \\
0.374 \\
0.418\end{array}$ & $\begin{array}{c}-0.373 * * * \\
0.066 \\
0.122 \\
0.339\end{array}$ \\
\hline Constant & $\begin{array}{l}0.435 \\
2.208\end{array}$ & $\begin{array}{l}1.612 \\
1.933\end{array}$ & $\begin{array}{l}2.338 \\
1.548\end{array}$ & $\begin{array}{c}3.561 * * * \\
1.098\end{array}$ & $\begin{array}{c}3.334 * * * \\
0.957\end{array}$ & $\begin{array}{c}2.952 * * * \\
0.893\end{array}$ & $\begin{array}{c}2.451 * * \\
0.969\end{array}$ & $\begin{array}{c}2.283 * * \\
0.929\end{array}$ & $\begin{array}{l}1.311^{*} \\
0.781\end{array}$ & $\begin{array}{c}1.808 * * * \\
0.651\end{array}$ & $\begin{array}{c}1.902 * * * \\
0.544\end{array}$ & $\begin{array}{c}1.936 * * * \\
0.451\end{array}$ \\
\hline $\begin{array}{l}\text { Firm Fixed Effects } \\
\text { Year Fixed Effects }\end{array}$ & $\begin{array}{l}\text { Yes } \\
\text { Yes }\end{array}$ & $\begin{array}{l}\text { Yes } \\
\text { Yes }\end{array}$ & $\begin{array}{l}\text { Yes } \\
\text { Yes }\end{array}$ & $\begin{array}{l}\text { Yes } \\
\text { Yes }\end{array}$ & $\begin{array}{l}\text { Yes } \\
\text { Yes }\end{array}$ & $\begin{array}{l}\text { Yes } \\
\text { Yes }\end{array}$ & $\begin{array}{l}\text { Yes } \\
\text { Yes }\end{array}$ & $\begin{array}{l}\text { Yes } \\
\text { Yes }\end{array}$ & $\begin{array}{l}\text { Yes } \\
\text { Yes }\end{array}$ & $\begin{array}{l}\text { Yes } \\
\text { Yes }\end{array}$ & $\begin{array}{l}\text { Yes } \\
\text { Yes }\end{array}$ & $\begin{array}{l}\text { Yes } \\
\text { Yes }\end{array}$ \\
\hline $\begin{array}{l}\text { Observations } \\
\text { R-squared } \\
\text { Number of Unique Firms }\end{array}$ & $\begin{array}{l}433 \\
0.19 \\
138\end{array}$ & $\begin{array}{c}519 \\
0.148 \\
150\end{array}$ & $\begin{array}{c}591 \\
0.15 \\
157\end{array}$ & $\begin{array}{c}650 \\
0.201 \\
162\end{array}$ & $\begin{array}{c}712 \\
0.205 \\
172\end{array}$ & $\begin{array}{c}849 \\
0.193 \\
246\end{array}$ & $\begin{array}{c}975 \\
0.233 \\
272\end{array}$ & $\begin{array}{c}1,574 \\
0.219 \\
737\end{array}$ & $\begin{array}{l}2,333 \\
0.173 \\
1,014\end{array}$ & $\begin{array}{l}3,192 \\
0.135 \\
1,231\end{array}$ & $\begin{array}{l}4,080 \\
0.108 \\
1,425\end{array}$ & $\begin{array}{l}5,066 \\
0.107 \\
1,648\end{array}$ \\
\hline
\end{tabular}


Table 5, Panel A: OLS regression analysis - Impact on mean analysts' recommendations for top two quartiles of mean house size

\begin{tabular}{|c|c|c|c|c|c|c|c|c|c|c|c|c|}
\hline \multirow[b]{2}{*}{ Dependent Variable } & \multicolumn{12}{|c|}{ Time Period } \\
\hline & $\begin{array}{l}\text { 1993-96 } \\
\text { meanrec }\end{array}$ & $\begin{array}{l}\text { 1993-97 } \\
\text { meanrec }\end{array}$ & $\begin{array}{l}1993-98 \\
\text { meanrec }\end{array}$ & $\begin{array}{l}1993-99 \\
\text { meanrec }\end{array}$ & $\begin{array}{l}\text { 1993-00 } \\
\text { meanrec }\end{array}$ & $\begin{array}{l}\text { 1993-01 } \\
\text { meanrec }\end{array}$ & $\begin{array}{l}\text { 1993-02 } \\
\text { meanrec }\end{array}$ & $\begin{array}{l}\text { 1993-03 } \\
\text { meanrec }\end{array}$ & $\begin{array}{l}\text { 1993-04 } \\
\text { meanrec }\end{array}$ & $\begin{array}{l}\text { 1993-05 } \\
\text { meanrec }\end{array}$ & $\begin{array}{l}\text { 1993-06 } \\
\text { meanrec }\end{array}$ & $\begin{array}{l}\text { 1993-07 } \\
\text { meanrec }\end{array}$ \\
\hline Total CSR Strengths & $\begin{array}{c}-0.087 * * * \\
0.023\end{array}$ & $\begin{array}{c}-0.079 * * * \\
0.021\end{array}$ & $\begin{array}{c}-\mathbf{0 . 0 6 8} * * * \\
0.019\end{array}$ & $\begin{array}{c}-\mathbf{0 . 0 5 5} * * * \\
0.017\end{array}$ & $\begin{array}{c}-0.049 * * * \\
0.016\end{array}$ & $\begin{array}{c}-0.023 * \\
0.013\end{array}$ & $\begin{array}{c}-0.016 \\
0.013\end{array}$ & $\begin{array}{l}0.009 \\
0.009\end{array}$ & $\begin{array}{l}0.011 \\
0.008\end{array}$ & $\begin{array}{c}\mathbf{0 . 0 1 3}^{*} \\
0.007\end{array}$ & $\begin{array}{l}\mathbf{0 . 0 1 1} \\
\mathbf{0 . 0 0 7}\end{array}$ & $\begin{array}{l}0.009 \\
0.006\end{array}$ \\
\hline Total CSR Concerns & $\begin{array}{c}-0.010 \\
0.018\end{array}$ & $\begin{array}{c}-0.006 \\
0.016\end{array}$ & $\begin{array}{c}-0.002 \\
0.014\end{array}$ & $\begin{array}{c}-0.003 \\
0.014\end{array}$ & $\begin{array}{c}-0.002 \\
0.013\end{array}$ & $\begin{array}{l}0.007 \\
0.011\end{array}$ & $\begin{array}{l}0.005 \\
0.012\end{array}$ & $\begin{array}{l}0.004 \\
0.010\end{array}$ & $\begin{array}{c}-0.007 \\
0.009\end{array}$ & $\begin{array}{l}-0.012 \\
0.008\end{array}$ & $\begin{array}{c}-0.013^{*} \\
0.008\end{array}$ & $\begin{array}{l}-0.011 \\
0.007\end{array}$ \\
\hline Number of Analysts & $\begin{array}{l}0.005 \\
0.005\end{array}$ & $\begin{array}{l}0.001 \\
0.004\end{array}$ & $\begin{array}{l}0.002 \\
0.003\end{array}$ & $\begin{array}{l}0.001 \\
0.003\end{array}$ & $\begin{array}{c}-0.002 \\
0.003\end{array}$ & $\begin{array}{c}-0.004 * \\
0.002\end{array}$ & $\begin{array}{c}-0.007 * * * \\
0.002\end{array}$ & $\begin{array}{c}-0.006 * * * \\
0.002\end{array}$ & $\begin{array}{c}-0.005 * * * \\
0.002\end{array}$ & $\begin{array}{c}-0.006 * * * \\
0.002\end{array}$ & $\begin{array}{c}-0.006 * * * \\
0.002\end{array}$ & $\begin{array}{c}-0.007 * * * \\
0.002\end{array}$ \\
\hline Mean House size & $\begin{array}{l}0.000 \\
0.000\end{array}$ & $\begin{array}{l}0.000 \\
0.000\end{array}$ & $\begin{array}{l}0.000 \\
0.000\end{array}$ & $\begin{array}{l}0.000 \\
0.000\end{array}$ & $\begin{array}{l}0.000 \\
0.000\end{array}$ & $\begin{array}{c}-0.000 * \\
0.000\end{array}$ & $\begin{array}{c}-0.000 * \\
0.000\end{array}$ & $\begin{array}{c}-0.000 * \\
0.000\end{array}$ & $\begin{array}{c}-0.000 * * \\
0.000\end{array}$ & $\begin{array}{c}-0.000 * * * \\
0.000\end{array}$ & $\begin{array}{c}-0.001 * * * \\
0.000\end{array}$ & $\begin{array}{c}-0.001 * * * \\
0.000\end{array}$ \\
\hline Long Term Forecast Error & $\begin{array}{l}0.193 \\
0.674\end{array}$ & $\begin{array}{l}0.032 \\
0.644\end{array}$ & $\begin{array}{l}0.718 \\
0.656\end{array}$ & $\begin{array}{l}0.599 \\
0.741\end{array}$ & $\begin{array}{l}0.553 \\
0.367\end{array}$ & $\begin{array}{c}0.980 * * * \\
0.356\end{array}$ & $\begin{array}{l}0.389 \\
0.336\end{array}$ & $\begin{array}{l}0.406 \\
0.316\end{array}$ & $\begin{array}{l}0.159 \\
0.242\end{array}$ & $\begin{array}{c}-0.079 \\
0.226\end{array}$ & $\begin{array}{l}0.004 \\
0.168\end{array}$ & $\begin{array}{l}0.050 \\
0.153\end{array}$ \\
\hline Market Value (Size) & $\begin{array}{c}0.338^{* * * *} \\
0.061\end{array}$ & $\begin{array}{c}0.246^{* * *} \\
0.049\end{array}$ & $\begin{array}{c}0.138 * * * \\
0.043\end{array}$ & $\begin{array}{c}0.069 * \\
0.036\end{array}$ & $\begin{array}{c}0.107 * * * \\
0.033\end{array}$ & $\begin{array}{c}0.126 * * * \\
0.031\end{array}$ & $\begin{array}{c}0.163^{* * *} * \\
0.027\end{array}$ & $\begin{array}{c}0.169 * * * \\
0.024\end{array}$ & $\begin{array}{c}0.171 * * * \\
0.023\end{array}$ & $\begin{array}{c}0.164 * * * \\
0.021\end{array}$ & $\begin{array}{c}0.172 * * * \\
0.020\end{array}$ & $\begin{array}{c}0.159 * * * \\
0.018\end{array}$ \\
\hline Market Adjusted Return & $\begin{array}{c}0.171^{* * * *} \\
0.038\end{array}$ & $\begin{array}{c}0.167 * * * \\
0.031\end{array}$ & $\begin{array}{c}0.166^{* * * *} \\
0.029\end{array}$ & $\begin{array}{c}0.119 * * * \\
0.021\end{array}$ & $\begin{array}{c}0.148 * * * \\
0.017\end{array}$ & $\begin{array}{c}0.148 * * * \\
0.016\end{array}$ & $\begin{array}{c}0.157 * * * \\
0.015\end{array}$ & $\begin{array}{c}0.152 * * * \\
0.015\end{array}$ & $\begin{array}{c}0.147 * * * \\
0.013\end{array}$ & $\begin{array}{c}0.125^{* * *} * \\
0.013\end{array}$ & $\begin{array}{c}0.115^{* * *} \\
0.012\end{array}$ & $\begin{array}{c}0.117 * * * \\
0.012\end{array}$ \\
\hline Intangibles & $\begin{array}{l}0.090 \\
0.217\end{array}$ & $\begin{array}{l}0.130 \\
0.161\end{array}$ & $\begin{array}{l}0.194 \\
0.157\end{array}$ & $\begin{array}{l}0.219 \\
0.153\end{array}$ & $\begin{array}{l}0.144 \\
0.146\end{array}$ & $\begin{array}{l}0.033 \\
0.131\end{array}$ & $\begin{array}{l}0.057 \\
0.110\end{array}$ & $\begin{array}{l}0.131 \\
0.101\end{array}$ & $\begin{array}{c}0.163^{*} \\
0.094\end{array}$ & $\begin{array}{c}0.222 * * \\
0.087\end{array}$ & $\begin{array}{c}0.241^{* * * *} \\
0.081\end{array}$ & $\begin{array}{c}0.283^{* * *} * \\
0.075\end{array}$ \\
\hline Return on Assets & $\begin{array}{l}0.332 \\
0.388\end{array}$ & $\begin{array}{c}0.562 * \\
0.336\end{array}$ & $\begin{array}{c}0.626^{* *} \\
0.269\end{array}$ & $\begin{array}{c}0.837 * * * \\
0.265\end{array}$ & $\begin{array}{c}1.006 * * * \\
0.226\end{array}$ & $\begin{array}{c}0.726^{* * * *} \\
0.200\end{array}$ & $\begin{array}{c}0.316^{*} \\
0.169\end{array}$ & $\begin{array}{l}0.248 \\
0.160\end{array}$ & $\begin{array}{c}0.262 * \\
0.143\end{array}$ & $\begin{array}{c}0.225^{*} \\
0.134\end{array}$ & $\begin{array}{l}0.189 \\
0.123\end{array}$ & $\begin{array}{c}0.221 * * \\
0.112\end{array}$ \\
\hline Earnings-to-price ratio & $\begin{array}{l}0.139 \\
0.183\end{array}$ & $\begin{array}{l}0.062 \\
0.180\end{array}$ & $\begin{array}{c}-0.036 \\
0.158\end{array}$ & $\begin{array}{l}0.058 \\
0.163\end{array}$ & $\begin{array}{c}-0.164 \\
0.136\end{array}$ & $\begin{array}{c}-0.170 \\
0.117\end{array}$ & $\begin{array}{c}0.136^{*} \\
0.080\end{array}$ & $\begin{array}{c}0.153 * * \\
0.066\end{array}$ & $\begin{array}{c}0.162^{* * * *} \\
0.061\end{array}$ & $\begin{array}{c}0.170 * * * \\
0.059\end{array}$ & $\begin{array}{c}0.198 * * * \\
0.060\end{array}$ & $\begin{array}{c}0.176^{* * * *} \\
0.048\end{array}$ \\
\hline $\begin{array}{l}\text { Book-to-Market ratio } \\
\text { Capital Expenditure }\end{array}$ & $\begin{array}{c}-0.519 * * * \\
0.114 \\
-0.214 \\
0.559\end{array}$ & $\begin{array}{c}-0.513 * * * \\
0.098 \\
0.042 \\
0.477\end{array}$ & $\begin{array}{c}-0.540 * * * \\
0.086 \\
0.035 \\
0.435\end{array}$ & $\begin{array}{c}-0.608 * * * \\
0.076 \\
0.173 \\
0.357\end{array}$ & $\begin{array}{c}-0.347 * * * \\
0.050 \\
0.217 \\
0.342\end{array}$ & $\begin{array}{c}-0.352 * * * \\
0.046 \\
0.356 \\
0.315\end{array}$ & $\begin{array}{c}-0.305 * * * \\
0.038 \\
0.431 \\
0.302\end{array}$ & $\begin{array}{c}-0.306^{* * *} \\
0.036 \\
0.296 \\
0.265\end{array}$ & $\begin{array}{c}-0.296 * * * \\
0.035 \\
0.214 \\
0.244\end{array}$ & $\begin{array}{c}-0.336^{* * *} \\
0.037 \\
0.135 \\
0.234\end{array}$ & $\begin{array}{c}-0.332 * * * \\
0.035 \\
0.174 \\
0.222\end{array}$ & $\begin{array}{c}-0.350 * * * \\
0.031 \\
0.210 \\
0.197\end{array}$ \\
\hline Constant & $\begin{array}{c}-1.220 \\
0.908\end{array}$ & $\begin{array}{l}0.181 \\
0.741\end{array}$ & $\begin{array}{c}1.772 * * * \\
0.655\end{array}$ & $\begin{array}{c}2.815 * * * \\
0.540\end{array}$ & $\begin{array}{c}2.158 * * * \\
0.484\end{array}$ & $\begin{array}{c}1.947 * * * \\
0.459\end{array}$ & $\begin{array}{c}1.438 * * * \\
0.424\end{array}$ & $\begin{array}{c}0.985^{* * *} * \\
0.375\end{array}$ & $\begin{array}{c}1.377 * * * \\
0.325\end{array}$ & $\begin{array}{c}1.132 * * * \\
0.328\end{array}$ & $\begin{array}{c}1.423 * * * \\
0.283\end{array}$ & $\begin{array}{c}1.612 * * * \\
0.259\end{array}$ \\
\hline $\begin{array}{l}\text { Firm Fixed Effects } \\
\text { Year Fixed Effects }\end{array}$ & $\begin{array}{l}\text { Yes } \\
\text { Yes }\end{array}$ & $\begin{array}{l}\text { Yes } \\
\text { Yes }\end{array}$ & $\begin{array}{l}\text { Yes } \\
\text { Yes }\end{array}$ & $\begin{array}{l}\text { Yes } \\
\text { Yes }\end{array}$ & $\begin{array}{l}\text { Yes } \\
\text { Yes }\end{array}$ & $\begin{array}{l}\text { Yes } \\
\text { Yes }\end{array}$ & $\begin{array}{l}\text { Yes } \\
\text { Yes }\end{array}$ & $\begin{array}{l}\text { Yes } \\
\text { Yes }\end{array}$ & $\begin{array}{l}\text { Yes } \\
\text { Yes }\end{array}$ & $\begin{array}{l}\text { Yes } \\
\text { Yes }\end{array}$ & $\begin{array}{l}\text { Yes } \\
\text { Yes }\end{array}$ & $\begin{array}{l}\text { Yes } \\
\text { Yes }\end{array}$ \\
\hline $\begin{array}{l}\text { Observations } \\
\text { R-squared } \\
\text { Number of Unique Firms }\end{array}$ & $\begin{array}{c}1,218 \\
0.208 \\
346\end{array}$ & $\begin{array}{c}1,557 \\
0.191 \\
374\end{array}$ & $\begin{array}{c}1,916 \\
0.185 \\
418\end{array}$ & $\begin{array}{c}2,297 \\
0.257 \\
464\end{array}$ & $\begin{array}{c}2,710 \\
0.259 \\
519\end{array}$ & $\begin{array}{c}3,479 \\
0.251 \\
871\end{array}$ & $\begin{array}{c}4,269 \\
0.395 \\
968\end{array}$ & $\begin{array}{l}5,440 \\
0.376 \\
1,325\end{array}$ & $\begin{array}{l}6,673 \\
0.343 \\
1,476\end{array}$ & $\begin{array}{l}7,957 \\
0.299 \\
1,613\end{array}$ & $\begin{array}{l}9,213 \\
0.276 \\
1,708\end{array}$ & $\begin{array}{c}10,494 \\
0.256 \\
1,821\end{array}$ \\
\hline
\end{tabular}


Table 5, Panel B: OLS regression analysis - Impact on mean analysts' recommendations for bottom two quartiles of mean house size

\begin{tabular}{|c|c|c|c|c|c|c|c|c|c|c|c|c|}
\hline & \multicolumn{12}{|c|}{ Time Period } \\
\hline Dependent Variable & $\begin{array}{l}\text { 1993-96 } \\
\text { meanrec }\end{array}$ & $\begin{array}{l}\text { 1993-97 } \\
\text { meanrec }\end{array}$ & $\begin{array}{l}1993-98 \\
\text { meanrec }\end{array}$ & $\begin{array}{l}\text { 1993-99 } \\
\text { meanrec }\end{array}$ & $\begin{array}{l}\text { 1993-00 } \\
\text { meanrec }\end{array}$ & $\begin{array}{l}\text { 1993-01 } \\
\text { meanrec }\end{array}$ & $\begin{array}{l}\text { 1993-02 } \\
\text { meanrec }\end{array}$ & $\begin{array}{l}\text { 1993-03 } \\
\text { meanrec }\end{array}$ & $\begin{array}{l}\text { 1993-04 } \\
\text { meanrec }\end{array}$ & $\begin{array}{l}\text { 1993-05 } \\
\text { meanrec }\end{array}$ & $\begin{array}{l}\text { 1993-06 } \\
\text { meanrec }\end{array}$ & $\begin{array}{l}\text { 1993-07 } \\
\text { meanrec }\end{array}$ \\
\hline Total CSR Strengths & $\begin{array}{c}-0.029 \\
0.070\end{array}$ & $\begin{array}{c}-0.059 \\
0.074\end{array}$ & $\begin{array}{r}-0.047 \\
0.074\end{array}$ & $\begin{array}{c}-0.023 \\
0.068\end{array}$ & $\begin{array}{c}-0.011 \\
0.066\end{array}$ & $\begin{array}{c}\mathbf{- 0 . 0 4 7} \\
\mathbf{0 . 0 4 8}\end{array}$ & $\begin{array}{c}-0.112 * * * \\
0.039\end{array}$ & $\begin{array}{c}-0.086 * * \\
0.035\end{array}$ & $\begin{array}{c}-\mathbf{- 0 . 0 7 0} * * \\
0.030\end{array}$ & $\begin{array}{c}-0.042 * * \\
0.020\end{array}$ & \begin{tabular}{|c|}
-0.022 \\
0.018
\end{tabular} & \begin{tabular}{|c|}
-0.018 \\
0.017
\end{tabular} \\
\hline Total CSR Concerns & $\begin{array}{l}0.020 \\
0.067\end{array}$ & $\begin{array}{l}0.009 \\
0.064\end{array}$ & $\begin{array}{l}0.012 \\
0.058\end{array}$ & $\begin{array}{l}0.009 \\
0.052\end{array}$ & $\begin{array}{l}0.018 \\
0.052\end{array}$ & $\begin{array}{l}0.028 \\
0.046\end{array}$ & $\begin{array}{l}0.058 \\
0.044\end{array}$ & $\begin{array}{l}0.011 \\
0.042\end{array}$ & $\begin{array}{c}-0.014 \\
0.027\end{array}$ & $\begin{array}{l}0.010 \\
0.020\end{array}$ & $\begin{array}{l}0.012 \\
0.019\end{array}$ & $\begin{array}{l}0.010 \\
0.019\end{array}$ \\
\hline Number of Analysts & $\begin{array}{c}-0.012 \\
0.015\end{array}$ & $\begin{array}{c}-0.009 \\
0.014\end{array}$ & $\begin{array}{c}-0.004 \\
0.013\end{array}$ & $\begin{array}{c}-0.001 \\
0.011\end{array}$ & $\begin{array}{c}-0.004 \\
0.011\end{array}$ & $\begin{array}{c}-0.001 \\
0.009\end{array}$ & $\begin{array}{l}0.000 \\
0.010\end{array}$ & $\begin{array}{l}0.006 \\
0.009\end{array}$ & $\begin{array}{l}0.001 \\
0.007\end{array}$ & $\begin{array}{c}-0.010^{*} \\
0.005\end{array}$ & $\begin{array}{c}-0.005 \\
0.004\end{array}$ & $\begin{array}{c}-0.013 * * * \\
0.004\end{array}$ \\
\hline Mean House size & $\begin{array}{c}-0.001 \\
0.002\end{array}$ & $\begin{array}{c}-0.001 \\
0.001\end{array}$ & $\begin{array}{l}0.001 \\
0.001\end{array}$ & $\begin{array}{c}0.001 * \\
0.001\end{array}$ & $\begin{array}{l}0.001 \\
0.001\end{array}$ & $\begin{array}{l}0.000 \\
0.001\end{array}$ & $\begin{array}{l}0.000 \\
0.001\end{array}$ & $\begin{array}{l}0.000 \\
0.001\end{array}$ & $\begin{array}{l}0.000 \\
0.000\end{array}$ & $\begin{array}{l}0.000 \\
0.000\end{array}$ & $\begin{array}{l}0.000 \\
0.000\end{array}$ & $\begin{array}{l}0.000 \\
0.000\end{array}$ \\
\hline Long Term Forecast Error & $\begin{array}{c}-0.841 \\
1.400\end{array}$ & $\begin{array}{c}-0.553 \\
1.390\end{array}$ & $\begin{array}{l}0.372 \\
1.242\end{array}$ & $\begin{array}{l}0.440 \\
1.222\end{array}$ & $\begin{array}{l}0.675 \\
1.014\end{array}$ & $\begin{array}{l}0.448 \\
0.970\end{array}$ & $\begin{array}{l}0.335 \\
0.930\end{array}$ & $\begin{array}{l}0.699 \\
0.843\end{array}$ & $\begin{array}{l}0.057 \\
0.537\end{array}$ & $\begin{array}{l}0.110 \\
0.388\end{array}$ & $\begin{array}{c}-0.098 \\
0.328\end{array}$ & $\begin{array}{c}-0.104 \\
0.262\end{array}$ \\
\hline Market Value (Size) & $\begin{array}{l}0.375 \\
0.240\end{array}$ & $\begin{array}{l}0.269 \\
0.204\end{array}$ & $\begin{array}{l}0.086 \\
0.151\end{array}$ & $\begin{array}{c}-0.001 \\
0.103\end{array}$ & $\begin{array}{l}0.039 \\
0.084\end{array}$ & $\begin{array}{l}0.068 \\
0.081\end{array}$ & $\begin{array}{l}0.094 \\
0.080\end{array}$ & $\begin{array}{l}0.130 \\
0.092\end{array}$ & $\begin{array}{c}0.171^{* *} \\
0.068\end{array}$ & $\begin{array}{c}0.123 * * \\
0.050\end{array}$ & $\begin{array}{c}0.137 * * * \\
0.043\end{array}$ & $\begin{array}{c}0.132 * * * \\
0.035\end{array}$ \\
\hline Market Adjusted Return & $\begin{array}{c}0.198 * \\
0.104\end{array}$ & $\begin{array}{c}0.275^{* *} \\
0.108\end{array}$ & $\begin{array}{c}0.267 * * * \\
0.097\end{array}$ & $\begin{array}{c}0.184 * * \\
0.084\end{array}$ & $\begin{array}{c}0.184 * * * \\
0.067\end{array}$ & $\begin{array}{c}0.185 * * \\
0.072\end{array}$ & $\begin{array}{c}0.186^{* * * *} \\
0.070\end{array}$ & $\begin{array}{c}0.231 * * * \\
0.066\end{array}$ & $\begin{array}{c}0.146^{* * *} * \\
0.034\end{array}$ & $\begin{array}{c}0.111 * * * \\
0.026\end{array}$ & $\begin{array}{c}0.097 * * * \\
0.022\end{array}$ & $\begin{array}{c}0.103 * * * \\
0.021\end{array}$ \\
\hline Intangibles & $\begin{array}{l}0.513 \\
0.714\end{array}$ & $\begin{array}{l}0.652 \\
0.604\end{array}$ & $\begin{array}{l}0.468 \\
0.457\end{array}$ & $\begin{array}{l}0.396 \\
0.389\end{array}$ & $\begin{array}{l}0.246 \\
0.330\end{array}$ & $\begin{array}{l}0.403 \\
0.303\end{array}$ & $\begin{array}{l}0.345 \\
0.284\end{array}$ & $\begin{array}{l}0.281 \\
0.344\end{array}$ & $\begin{array}{l}0.288 \\
0.243\end{array}$ & $\begin{array}{c}-0.023 \\
0.184\end{array}$ & $\begin{array}{c}-0.202 \\
0.146\end{array}$ & $\begin{array}{l}0.006 \\
0.119\end{array}$ \\
\hline Return on Assets & $\begin{array}{l}0.935 \\
1.050\end{array}$ & $\begin{array}{l}0.298 \\
0.862\end{array}$ & $\begin{array}{l}0.601 \\
0.811\end{array}$ & $\begin{array}{l}1.308 \\
0.825\end{array}$ & $\begin{array}{c}1.535^{* *} \\
0.679\end{array}$ & $\begin{array}{c}1.469 * * \\
0.668\end{array}$ & $\begin{array}{c}1.570 * * * \\
0.511\end{array}$ & $\begin{array}{c}1.161 * * \\
0.531\end{array}$ & $\begin{array}{c}1.012 * * * \\
0.347\end{array}$ & $\begin{array}{c}0.847 * * * \\
0.237\end{array}$ & $\begin{array}{c}0.459 * * \\
0.215\end{array}$ & $\begin{array}{c}0.405^{* *} \\
0.205\end{array}$ \\
\hline Earnings-to-price ratio & $\begin{array}{l}0.382 \\
0.573\end{array}$ & $\begin{array}{l}0.895 \\
0.550\end{array}$ & $\begin{array}{l}0.360 \\
0.552\end{array}$ & $\begin{array}{c}-0.012 \\
0.492\end{array}$ & $\begin{array}{c}-0.497 \\
0.396\end{array}$ & $\begin{array}{c}-0.402 \\
0.408\end{array}$ & $\begin{array}{c}-0.247 \\
0.282\end{array}$ & $\begin{array}{c}-0.225 \\
0.200\end{array}$ & $\begin{array}{c}-0.013 \\
0.190\end{array}$ & $\begin{array}{l}0.089 \\
0.159\end{array}$ & $\begin{array}{c}0.361 * * \\
0.162\end{array}$ & $\begin{array}{c}0.287 * * \\
0.134\end{array}$ \\
\hline Book-to-Market ratio & $\begin{array}{c}-0.133 \\
0.248\end{array}$ & $\begin{array}{c}-0.157 \\
0.248\end{array}$ & $\begin{array}{c}-0.558 * * \\
0.222\end{array}$ & $\begin{array}{c}-0.767 * * * \\
0.207\end{array}$ & $\begin{array}{c}-0.636 * * * \\
0.176\end{array}$ & $\begin{array}{c}-0.491 * * \\
0.190\end{array}$ & $\begin{array}{c}-0.357 * * \\
0.176\end{array}$ & $\begin{array}{c}-0.361 * * \\
0.173\end{array}$ & $\begin{array}{c}-0.340 * * * \\
0.119\end{array}$ & $\begin{array}{c}-0.367 * * * \\
0.095\end{array}$ & $\begin{array}{c}-0.332 * * * \\
0.080\end{array}$ & $\begin{array}{c}-0.361 * * * \\
0.066\end{array}$ \\
\hline Capital Expenditure & $\begin{array}{l}0.512 \\
1.150\end{array}$ & $\begin{array}{l}1.129 \\
0.868\end{array}$ & $\begin{array}{l}0.920 \\
0.720\end{array}$ & $\begin{array}{l}0.844 \\
0.697\end{array}$ & $\begin{array}{l}0.863 \\
0.688\end{array}$ & $\begin{array}{l}1.118 \\
0.721\end{array}$ & $\begin{array}{l}0.988 \\
0.663\end{array}$ & $\begin{array}{l}0.942 \\
0.707\end{array}$ & $\begin{array}{c}0.927 * \\
0.552\end{array}$ & $\begin{array}{l}0.665 \\
0.472\end{array}$ & $\begin{array}{c}0.652^{*} \\
0.368\end{array}$ & $\begin{array}{l}0.367 \\
0.338\end{array}$ \\
\hline Constant & $\begin{array}{c}-1.438 \\
3.234\end{array}$ & $\begin{array}{c}-0.012 \\
2.703\end{array}$ & $\begin{array}{l}2.515 \\
2.012\end{array}$ & $\begin{array}{c}4.071 * * * \\
1.437\end{array}$ & $\begin{array}{c}3.087 * * * \\
1.150\end{array}$ & $\begin{array}{c}2.930 * * \\
1.182\end{array}$ & $\begin{array}{c}2.412 * * \\
1.102\end{array}$ & $\begin{array}{l}2.000 \\
1.230\end{array}$ & $\begin{array}{c}1.751^{*} \\
0.903\end{array}$ & $\begin{array}{c}2.498 * * * \\
0.677\end{array}$ & $\begin{array}{c}2.373 * * * \\
0.583\end{array}$ & $\begin{array}{c}2.524 * * * \\
0.482\end{array}$ \\
\hline $\begin{array}{l}\text { Firm Fixed Effects } \\
\text { Year Fixed Effects }\end{array}$ & $\begin{array}{l}\text { Yes } \\
\text { Yes }\end{array}$ & $\begin{array}{l}\text { Yes } \\
\text { Yes }\end{array}$ & $\begin{array}{l}\text { Yes } \\
\text { Yes }\end{array}$ & $\begin{array}{l}\text { Yes } \\
\text { Yes }\end{array}$ & $\begin{array}{l}\text { Yes } \\
\text { Yes }\end{array}$ & $\begin{array}{l}\text { Yes } \\
\text { Yes }\end{array}$ & $\begin{array}{l}\text { Yes } \\
\text { Yes }\end{array}$ & $\begin{array}{l}\text { Yes } \\
\text { Yes }\end{array}$ & $\begin{array}{l}\text { Yes } \\
\text { Yes }\end{array}$ & $\begin{array}{l}\text { Yes } \\
\text { Yes }\end{array}$ & $\begin{array}{l}\text { Yes } \\
\text { Yes }\end{array}$ & $\begin{array}{l}\text { Yes } \\
\text { Yes }\end{array}$ \\
\hline $\begin{array}{l}\text { Observations } \\
\text { R-squared } \\
\text { Number of Unique Firms }\end{array}$ & $\begin{array}{c}249 \\
0.184 \\
81\end{array}$ & $\begin{array}{c}298 \\
0.161 \\
86\end{array}$ & $\begin{array}{c}344 \\
0.179 \\
91\end{array}$ & $\begin{array}{c}385 \\
0.239 \\
96\end{array}$ & $\begin{array}{c}422 \\
0.239 \\
98\end{array}$ & $\begin{array}{c}503 \\
0.219 \\
143\end{array}$ & $\begin{array}{c}602 \\
0.212 \\
181\end{array}$ & $\begin{array}{c}1,527 \\
0.196 \\
995\end{array}$ & $\begin{array}{l}2,521 \\
0.129 \\
1,249\end{array}$ & $\begin{array}{l}3,539 \\
0.098 \\
1,427\end{array}$ & $\begin{array}{l}4,540 \\
0.088 \\
1,583\end{array}$ & $\begin{array}{l}5,570 \\
0.083 \\
1,759\end{array}$ \\
\hline
\end{tabular}


Table 6: OLS regression analysis - Impact of CSR on analysts' forecast error, adding years

\begin{tabular}{|c|c|c|c|c|c|c|c|c|c|c|c|c|}
\hline & \multicolumn{12}{|c|}{ Time Period } \\
\hline Dependent Variable & $\begin{array}{l}\text { 1993-96 } \\
\text { Forc. } \\
\text { Error. }\end{array}$ & $\begin{array}{l}\text { 1993-97 } \\
\text { Forc. } \\
\text { Error. }\end{array}$ & $\begin{array}{l}\text { 1993-98 } \\
\text { Forc. } \\
\text { Error. }\end{array}$ & $\begin{array}{l}\text { 1993-99 } \\
\text { Forc. } \\
\text { Error. }\end{array}$ & $\begin{array}{l}\text { 1993-00 } \\
\text { Forc. } \\
\text { Error. }\end{array}$ & $\begin{array}{l}\text { 1993-01 } \\
\text { Forc. } \\
\text { Error. }\end{array}$ & $\begin{array}{l}\text { 1993-02 } \\
\text { Forc. } \\
\text { Error. }\end{array}$ & $\begin{array}{l}\text { 1993-03 } \\
\text { Forc. } \\
\text { Error. }\end{array}$ & $\begin{array}{l}\text { 1993-04 } \\
\text { Forc. } \\
\text { Error. }\end{array}$ & $\begin{array}{l}\text { 1993-05 } \\
\text { Forc. } \\
\text { Error. }\end{array}$ & $\begin{array}{l}\text { 1993-06 } \\
\text { Forc. } \\
\text { Error. }\end{array}$ & $\begin{array}{l}\text { 1993-07 } \\
\text { Forc. } \\
\text { Error. }\end{array}$ \\
\hline Total CSR Strengths & $\begin{array}{c}-0.001 \\
0.001\end{array}$ & $\begin{array}{c}-0.001 \\
0.001\end{array}$ & $\begin{array}{l}0.000 \\
0.001\end{array}$ & $\begin{array}{l}0.000 \\
0.001\end{array}$ & $\begin{array}{l}0.000 \\
0.001\end{array}$ & $\begin{array}{l}0.000 \\
0.001\end{array}$ & $\begin{array}{l}0.000 \\
0.001\end{array}$ & $\begin{array}{l}0.000 \\
0.000\end{array}$ & $\begin{array}{l}0.000 \\
0.000\end{array}$ & $\begin{array}{l}0.000 \\
0.000\end{array}$ & $\begin{array}{l}0.000 \\
0.000\end{array}$ & $\begin{array}{l}0.000 \\
0.000\end{array}$ \\
\hline Total CSR Concerns & $\begin{array}{l}0.001 \\
0.001\end{array}$ & $\begin{array}{l}0.001 \\
0.001\end{array}$ & $\begin{array}{l}0.000 \\
0.001\end{array}$ & $\begin{array}{l}0.000 \\
0.001\end{array}$ & $\begin{array}{l}0.000 \\
0.001\end{array}$ & $\begin{array}{l}0.001 \\
0.001\end{array}$ & $\begin{array}{l}0.001 \\
0.001\end{array}$ & $\begin{array}{l}0.000 \\
0.000\end{array}$ & $\begin{array}{l}0.000 \\
0.000\end{array}$ & $\begin{array}{l}0.000 \\
0.000\end{array}$ & $\begin{array}{l}0.000 \\
0.000\end{array}$ & $\begin{array}{l}0.000 \\
0.000\end{array}$ \\
\hline Horizon Control & $\begin{array}{l}0.014 \\
0.032\end{array}$ & $\begin{array}{l}-0.014 \\
0.024\end{array}$ & $\begin{array}{l}0.005 \\
0.024\end{array}$ & $\begin{array}{c}-0.007 \\
0.018\end{array}$ & $\begin{array}{l}0.011 \\
0.019\end{array}$ & $\begin{array}{l}0.009 \\
0.018\end{array}$ & $\begin{array}{l}0.011 \\
0.014\end{array}$ & $\begin{array}{l}0.007 \\
0.011\end{array}$ & $\begin{array}{c}-0.006 \\
0.010\end{array}$ & $\begin{array}{l}0.003 \\
0.011\end{array}$ & $\begin{array}{c}-0.012 \\
0.013\end{array}$ & $\begin{array}{l}0.011 \\
0.015\end{array}$ \\
\hline Number of Analysts & $\begin{array}{l}0.000 \\
0.000\end{array}$ & $\begin{array}{l}0.000 \\
0.000\end{array}$ & $\begin{array}{l}0.000 \\
0.000\end{array}$ & $\begin{array}{l}0.000 \\
0.000\end{array}$ & $\begin{array}{l}0.000 \\
0.000\end{array}$ & $\begin{array}{l}0.000 \\
0.000\end{array}$ & $\begin{array}{l}0.000 \\
0.000\end{array}$ & $\begin{array}{l}0.000 \\
0.000\end{array}$ & $\begin{array}{l}0.000 \\
0.000\end{array}$ & $\begin{array}{l}0.000 \\
0.000\end{array}$ & $\begin{array}{l}0.000 \\
0.000\end{array}$ & $\begin{array}{l}0.000 \\
0.000\end{array}$ \\
\hline Market Value (Size) & $\begin{array}{c}0.015^{* *} \\
0.007\end{array}$ & $\begin{array}{c}0.009 * * \\
0.004\end{array}$ & $\begin{array}{c}0.010^{* * *} \\
0.003\end{array}$ & $\begin{array}{c}0.007 * * * \\
0.002\end{array}$ & $\begin{array}{c}0.004^{*} \\
0.002\end{array}$ & $\begin{array}{l}0.003 \\
0.002\end{array}$ & $\begin{array}{l}0.003 \\
0.003\end{array}$ & $\begin{array}{l}0.003 \\
0.003\end{array}$ & $\begin{array}{l}0.001 \\
0.002\end{array}$ & $\begin{array}{l}0.002 \\
0.002\end{array}$ & $\begin{array}{c}0.004 * * \\
0.002\end{array}$ & $\begin{array}{c}0.003^{*} \\
0.002\end{array}$ \\
\hline Market Adjusted Return & $\begin{array}{l}-0.006 \\
0.004\end{array}$ & $\begin{array}{c}-0.005^{* *} \\
0.003\end{array}$ & $\begin{array}{c}-0.006 * * * \\
0.002\end{array}$ & $\begin{array}{c}-0.006^{* * *} \\
0.002\end{array}$ & $\begin{array}{c}-0.003 * * \\
0.001\end{array}$ & $\begin{array}{c}-0.002 * * \\
0.001\end{array}$ & $\begin{array}{c}-0.002 * * \\
0.001\end{array}$ & $\begin{array}{l}-0.002 \\
0.001\end{array}$ & $\begin{array}{c}-0.001 \\
0.001\end{array}$ & $\begin{array}{c}-0.001 \\
0.001\end{array}$ & $\begin{array}{c}-0.002 * * \\
0.001\end{array}$ & $\begin{array}{c}-0.002 * * * \\
0.001\end{array}$ \\
\hline Intangibles & $\begin{array}{c}-0.010 \\
0.010\end{array}$ & $\begin{array}{c}-0.006 \\
0.007\end{array}$ & $\begin{array}{c}-0.010 \\
0.007\end{array}$ & $\begin{array}{c}-0.006 \\
0.007\end{array}$ & $\begin{array}{c}-0.004 \\
0.007\end{array}$ & $\begin{array}{c}-0.006 \\
0.005\end{array}$ & $\begin{array}{c}-0.004 \\
0.006\end{array}$ & $\begin{array}{l}-0.004 \\
0.004\end{array}$ & $\begin{array}{c}-0.004 \\
0.004\end{array}$ & $\begin{array}{c}-0.006^{*} \\
0.003\end{array}$ & $\begin{array}{c}-0.012 * * * \\
0.003\end{array}$ & $\begin{array}{c}-0.018 * * * \\
0.005\end{array}$ \\
\hline Return on Assets & $\begin{array}{l}0.027 \\
0.040\end{array}$ & $\begin{array}{l}0.036 \\
0.031\end{array}$ & $\begin{array}{l}0.028 \\
0.023\end{array}$ & $\begin{array}{l}0.003 \\
0.023\end{array}$ & $\begin{array}{l}-0.004 \\
0.019\end{array}$ & $\begin{array}{l}-0.010 \\
0.016\end{array}$ & $\begin{array}{l}-0.014 \\
0.015\end{array}$ & $\begin{array}{l}-0.009 \\
0.013\end{array}$ & $\begin{array}{l}-0.006 \\
0.010\end{array}$ & $\begin{array}{l}0.000 \\
0.009\end{array}$ & $\begin{array}{c}-0.003 \\
0.008\end{array}$ & $\begin{array}{c}-0.017 * \\
0.010\end{array}$ \\
\hline Book-to-Market ratio & $\begin{array}{c}0.037^{*} \\
0.020\end{array}$ & $\begin{array}{c}0.028^{*} \\
0.016\end{array}$ & $\begin{array}{c}0.026^{* *} \\
0.012\end{array}$ & $\begin{array}{c}0.015^{*} \\
0.009\end{array}$ & $\begin{array}{c}0.017 * \\
0.009\end{array}$ & $\begin{array}{c}0.017 * * \\
0.008\end{array}$ & $\begin{array}{c}0.014 * \\
0.007\end{array}$ & $\begin{array}{c}0.013^{* *} \\
0.006\end{array}$ & $\begin{array}{c}0.009^{*} \\
0.005\end{array}$ & $\begin{array}{c}0.013 * * * \\
0.004\end{array}$ & $\begin{array}{c}0.020 * * * \\
0.004\end{array}$ & $\begin{array}{c}0.030 * * * \\
0.005\end{array}$ \\
\hline Capital Expenditure & $\begin{array}{l}-0.020 \\
0.039\end{array}$ & $\begin{array}{l}0.015 \\
0.028\end{array}$ & $\begin{array}{l}0.013 \\
0.025\end{array}$ & $\begin{array}{l}0.011 \\
0.023\end{array}$ & $\begin{array}{c}0.042^{*} \\
0.023\end{array}$ & $\begin{array}{c}0.043^{*} \\
0.022\end{array}$ & $\begin{array}{c}0.052 * * * \\
0.020\end{array}$ & $\begin{array}{c}0.037 * * \\
0.016\end{array}$ & $\begin{array}{l}0.016 \\
0.013\end{array}$ & $\begin{array}{l}0.018 \\
0.012\end{array}$ & $\begin{array}{l}0.017 \\
0.011\end{array}$ & $\begin{array}{l}0.008 \\
0.011\end{array}$ \\
\hline Constant & $\begin{array}{c}-0.307^{*} \\
0.185\end{array}$ & $\begin{array}{l}-0.082 \\
0.126\end{array}$ & $\begin{array}{l}-0.182 \\
0.125\end{array}$ & $\begin{array}{c}-0.071 \\
0.090\end{array}$ & $\begin{array}{l}-0.114 \\
0.106\end{array}$ & $\begin{array}{c}-0.092 \\
0.102\end{array}$ & $\begin{array}{l}-0.100 \\
0.089\end{array}$ & $\begin{array}{l}-0.075 \\
0.066\end{array}$ & $\begin{array}{l}0.012 \\
0.061\end{array}$ & $\begin{array}{l}-0.043 \\
0.060\end{array}$ & $\begin{array}{l}0.001 \\
0.067\end{array}$ & $\begin{array}{l}-0.093 \\
0.078\end{array}$ \\
\hline $\begin{array}{l}\text { Firm Fixed Effects } \\
\text { Year Fixed Effects }\end{array}$ & $\begin{array}{l}\text { Yes } \\
\text { Yes }\end{array}$ & $\begin{array}{l}\text { Yes } \\
\text { Yes }\end{array}$ & $\begin{array}{l}\text { Yes } \\
\text { Yes }\end{array}$ & $\begin{array}{l}\text { Yes } \\
\text { Yes }\end{array}$ & $\begin{array}{l}\text { Yes } \\
\text { Yes }\end{array}$ & $\begin{array}{l}\text { Yes } \\
\text { Yes }\end{array}$ & $\begin{array}{l}\text { Yes } \\
\text { Yes }\end{array}$ & $\begin{array}{l}\text { Yes } \\
\text { Yes }\end{array}$ & $\begin{array}{l}\text { Yes } \\
\text { Yes }\end{array}$ & $\begin{array}{l}\text { Yes } \\
\text { Yes }\end{array}$ & $\begin{array}{l}\text { Yes } \\
\text { Yes }\end{array}$ & $\begin{array}{l}\text { Yes } \\
\text { Yes }\end{array}$ \\
\hline $\begin{array}{l}\text { Observations } \\
\text { R-squared } \\
\text { Number of Unique Firms }\end{array}$ & $\begin{array}{c}1,542 \\
0.065 \\
436\end{array}$ & $\begin{array}{c}1,939 \\
0.056 \\
467\end{array}$ & $\begin{array}{c}2,358 \\
0.063 \\
519\end{array}$ & $\begin{array}{c}2,802 \\
0.043 \\
569\end{array}$ & $\begin{array}{c}3,280 \\
0.053 \\
627\end{array}$ & $\begin{array}{l}4,136 \\
0.052 \\
1,024\end{array}$ & $\begin{array}{l}5,042 \\
0.034 \\
1,162\end{array}$ & $\begin{array}{l}7,287 \\
0.027 \\
2,458\end{array}$ & $\begin{array}{l}9,661 \\
0.015 \\
2,832\end{array}$ & $\begin{array}{l}12,079 \\
0.017 \\
3,130\end{array}$ & $\begin{array}{c}14,446 \\
0.028 \\
3,382\end{array}$ & $\begin{array}{c}16,880 \\
0.069 \\
3,681\end{array}$ \\
\hline
\end{tabular}


Figure 1: Estimated coefficients on CSR strengths (Table 3, Panel B)

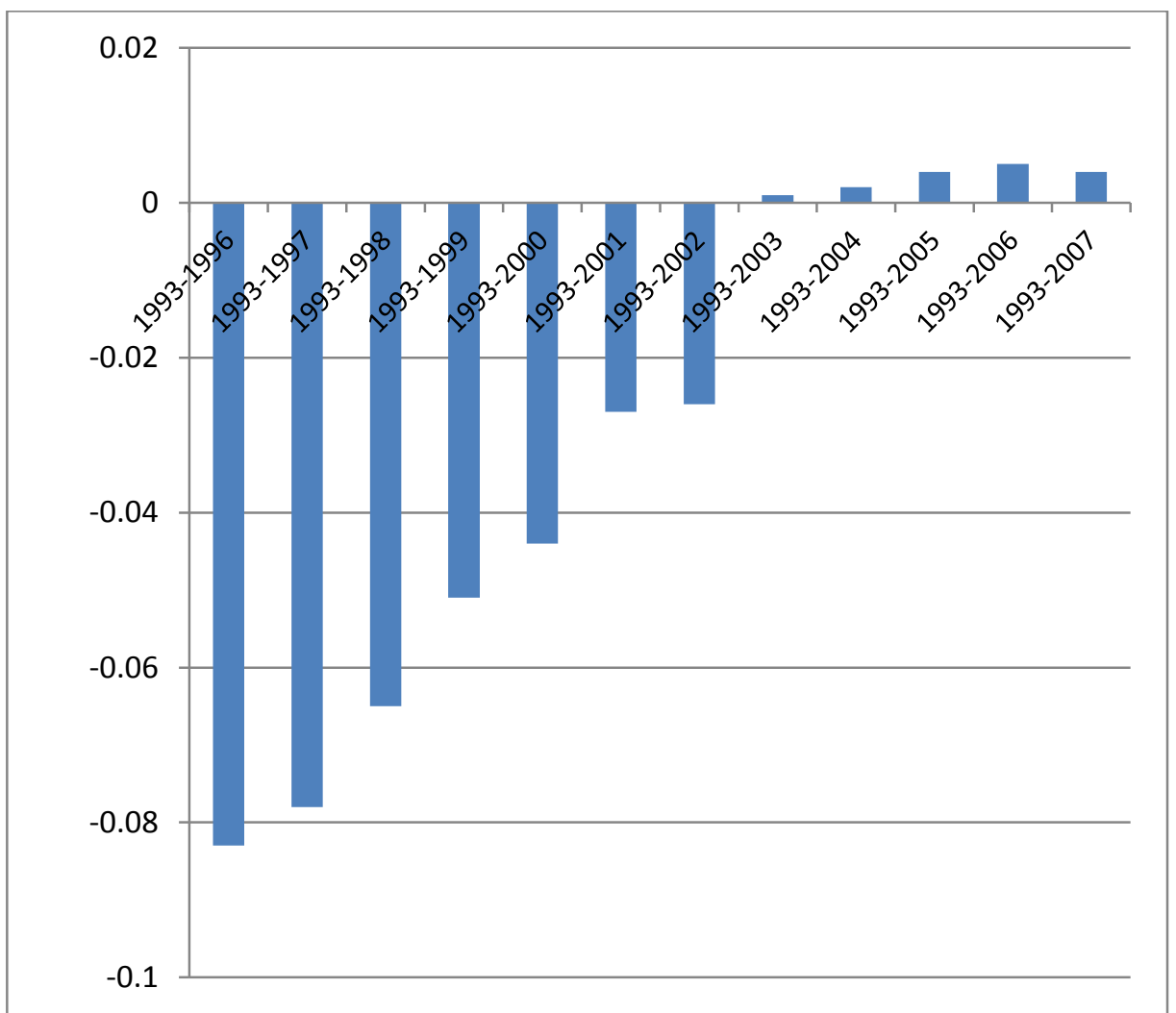

Figure 2: Estimated coefficients on CSR strengths for high and low legitimacy analysts (table 4)

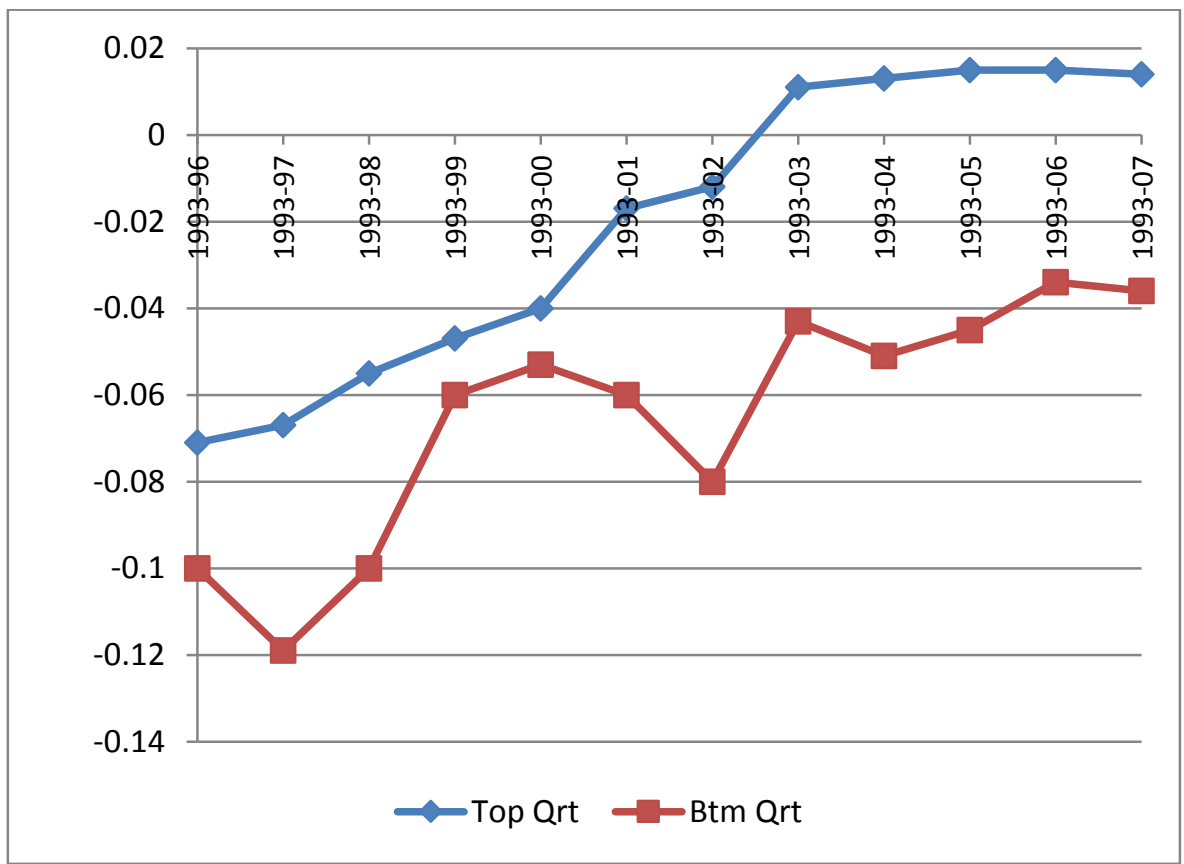




\section{REFERENCES}

2013.

Booz \& Company 2012. Responsible Investing: a Paradigm Shift. From Niche to Mainstream. (May 7th,

European Commission 2001. Promoting a European Framework for Corporate Social Responsibilities. In Green Paper. Office for Official Publications of the European Communities: Brussels, Belgium.

Abarbanell JS, Lanen WN, Verrecchia RE. 1995. Analysts' forecasts as proxies for investor beliefs in

empirical research. Journal of Accounting and Economics 20(1): 31-60.

Abolafia MY. 1996. Hyper-rational gaming. Journal of Contemporary Ethnography 25(2): 226-250.

Ambec S, Lanoie P. 2008. Does It Pay to Be Green? A Systematic Overview. Academy of Management

Perspectives 22(4): 45-62.

Andrews K. 1971. The Concept of Corporate Strategy. Dow-Jones Irwin: Homewood, Illinois.

Aragón-Correa JA. 1998. Strategic proactivity and firm approach to the natural environment. Academy of management Journal 41(5): 556-567.

Atkinson L, Galaskiewicz J. 1988. Stock ownership and company contributions to charity. Administrative Science Quarterly: 82-100.

Barber B, Lehavy R, McNichols M, Trueman B. 2001. Can investors profit from the prophets? Security

analyst recommendations and stock returns. The Journal of Finance 56(2): 531-563.

Barnett ML, Salomon RM. 2006. Beyond dichotomy: the curvilinear relationship between social responsibility and financial performance. Strategic Management Journal 27(11): 1101-1122.

Bear S, Rahman N, Post C. 2010. The impact of board diversity and gender composition on corporate social responsibility and firm reputation. Journal of Business Ethics 97(2): 207-221.

Benner MJ. 2007. The Incumbent Disound: Stock Market Categories and Response to Radical

Technological Change. Academy of Management Review 32(3): 703-720.

Benner MJ. 2010. Securities Analysts and Incumbent Response to Radical Technological Change:

Evidence from Digital Photography and Internet Telephony. Organization Science 21(1): 42-62.

Benner MJ, Ranganathan R. 2012. Offsetting illegitimacy? How pressures from securities analysts

influence incumbents in the face of new technologies. Academy of Management Journal 55(1): 213-233.

Berman SL, Wicks AC, Kotha S, Jones TM. 1999. Does Stakeholder Orientation Matter? The Relationship between Stakeholder Management Models and Firm Financial Performance. The Academy of Management Journal 42(5): 488-506.

Carroll AB. 1979. A Three-Dimensional Conceptual Model of Corporate Performance. The Academy of Management Review 4(4): 497-505.

Carroll AB, Lipartito KJ, Post JE, Werhane PH. 2012. Corporate Responsibility: The American

Experience. Cambridge University Press.

Cetina KK, Bruegger U. 2002. Global Microstructures: The Virtual Societies of Financial Markets1.

American Journal of Sociology 107(4): 905-950.

Chatterji AK, Levine DI, Toffel MW. 2009. How well do social ratings actually measure corporate social

responsibility? Journal of Economics \& Management Strategy 18(1): 125-169.

Cheng B, Ioannou I, Serafeim G. 2014. Corporate social responsibility and access to finance. Strategic

Management Journal 35(1): 1-23.

Choi J, Wang HL. 2009. Stakeholder Relations and the Persistence of Corporate Financial Performance.

Strategic Management Journal 30(8): 895-907.

Clement MB. 1999. Analyst forecast accuracy: Do ability, resources, and portfolio complexity matter?

Journal of Accounting and Economics 27(3): 285-303.

Clement MB, Tse SY. 2005. Financial analyst characteristics and herding behavior in forecasting. The

Journal of Finance 60(1): 307-341.

Cohen L, Frazzini A, Malloy C. 2010. Sell-Side School Ties. The Journal of Finance 65(4): 1409-1437.

Davis GF, Thompson TA. 1994. A social movement perspective on corporate control. Administrative

Science Quarterly: 141-173.

Davis K. 1973. The case for and against business assumption of social responsibilities. Academy of Management Journal 16(2): 312-322.

Delmas MA, Etzion D, Nairn-Birch N. 2013. Triangulating Environmental Performance: What Do

Corporate Social Responsibility Ratings Really Capture? The Academy of Management Perspectives 27(3): 255-267. 
Delmas MA, Montes-Sancho MJ. 2011. US state policies for renewable energy: Context and effectiveness. Energy Policy 39(5): 2273-2288.

Dewatripont M, Jewitt I, Tirole J. 1999. The economics of career concerns, part I: Comparing information structures. The Review of Economic Studies 66(1): 183-198.

Dixon-Fowler HR, Slater DJ, Johnson JL, Ellstrand AE, Romi AM. 2013. Beyond "Does it Pay to be Green?” A Meta-Analysis of Moderators of the CEP-CFP Relationship. Journal of business ethics 112(2): 353-366.

Donaldson T, Preston LE. 1995. The Stakeholder Theory of the Corporation: Concepts, Evidence, and Implications. Academy of Management Review 20(1): 65-91.

Durand R, Rao H, Monin P. 2007. Code and conduct in French cuisine: Impact of code changes on external evaluations. Strategic Management Journal 28(5): 455-472.

Eccles R, Ioannou I, Serafeim G. 2013. The Impact of a Corporate Sustainability on Organizational Processes and Performance. HBS Working Paper Series 11-016.

Eccles RG, Crane DB. 1987. Managing through networks in investment banking. California Management Review 30(1): 176-195.

Eccles RG, Krzus MP, Serafeim G. 2011. Market Interest in Nonfinancial Information. Journal of Applied Corporate Finance 23(4): 113-127.

Edward Freeman R, Evan WM. 1991. Corporate governance: A stakeholder interpretation. Journal of Behavioral Economics 19(4): 337-359.

El Ghoul S, Guedhami O, Kwok CC, Mishra DR. 2011. Does corporate social responsibility affect the cost of capital? Journal of Banking \& Finance 35(9): 2388-2406.

Eliashberg J, Shugan SM. 1997. Film critics: Influencers or predictors? The Journal of Marketing: 68-78.

Etzion D. 2007. Research on organizations and the natural environment, 1992-present: A review. Journal of Management 33(4): 637-664.

Fama EF. 1965. The behavior of stock-market prices. The journal of Business 38(1): 34-105.

Fama EF, Jensen MC. 1983a. Agency problems and residual claims. Journal of law and Economics 26(2): 327-349.

Fama EF, Jensen MC. 1983b. Separation of ownership and control. Journal of law and Economics 26(2): 301-325.

Fine GA. 1996. Reputational entrepreneurs and the memory of incompetence: Melting supporters, partisan warriors, and images of President Harding. American Journal of Sociology: 1159-1193.

Fisman R, Heal G, Nair VB. 2005. Corporate social responsibility: Doing well by doing good, SSRN working paper http://ssrn.com/abstract=813286.

Fombrun C. 2005. Building corporate reputation through CSR initiatives: evolving standards. Corporate Reputation Review 8(1): 7-11.

Fombrun C, Shanley M. 1990. What's in a name? Reputation building and corporate strategy. Academy of management Journal: 233-258.

Francis J, Soffer L. 1997. The relative informativeness of analysts' stock recommendations and earnings forecast revisions. Journal of Accounting Research 35(2): 193-211.

Freeman R. 1984. Strategic Management: A stakeholder perspective. Piman: Boston, MA.

Freeman RE, Harrison JS, Wicks AC. 2007. Managing for stakeholders: survival, reputation, and success.

Yale Univ Press: New Haven, CT.

Freeman RE, Harrison JS, Wicks AC, Parmar BL, De Colle S. 2010. Stakeholder theory: The state of the art. Cambridge University Press.

Fried D, Givoly D. 1982. Financial analysts' forecasts of earnings: a better surrogate for market expectations. Journal of Accounting and Economics 4(2): 85-107.

Friedman M. 1962. Capitalism and freedom. University of Chicago press.

Friedman M. 1970. The social responsibility of business is to increase its profits. New York Times Magazine 32(13): 122-126.

Galaskiewicz J. 1997. An urban grants economy revisited: Corporate charitable contributions in the Twin Cities, 1979-81, 1987-89. Administrative Science Quarterly: 445-471.

Glac K. 2010. The Influence of Shareholders on Corporate Social Responsibility, Working Paper, University of St. Thomas.

Godfrey PC. 2005. The relationship Between Corporate Philanthropy and Shareholder Wealth: A Risk Management Perspective Academy of Management Review 30(4): 777-798. 
Godfrey PC, Merrill CB, Hansen JM. 2009. The relationship between corporate social responsibility and shareholder value: an empirical test of the risk management hypothesis. Strategic Management Journal 30(4): 425445.

Goss A, Roberts GS. 2011. The impact of corporate social responsibility on the cost of bank loans. Journal of Banking \& Finance 35(7): 1794-1810.

Graves SB, Waddock SA. 1994. Institutional owners and corporate social performance. The Academy of Management Journal 37(4): 1034-1046.

Hannan MT, Polos L, Carroll GR. 2004. The evolution of inertia. Industrial and Corporate Change 13(1): 213-242. 986-1014.

Hart SL. 1995. A Natural-Resource-Based View of the Firm. The Academy of Management Review 20(4):

Hillman AJ, Keim GD. 2001. Shareholder Value, Stakeholder Management, and Social Issues: What's the Bottom Line? Strategic Management Journal 22(2): 125-139.

Hirsch PM. 1972. Processing fads and fashions: An organization-set analysis of cultural industry systems. American journal of sociology: 639-659.

Hong H, Kubik JD. 2003. Analyzing the analysts: Career concerns and biased earnings forecasts. The Journal of Finance 58(1): 313-351.

Hong H, Kubik JD, Solomon A. 2000. Security analysts' career concerns and herding of earnings forecasts.

The Rand Journal of Economics: 121-144.

Ioannou I, Serafeim G. 2012. The Consequences of Mandatory Corporate Sustainability Reporting.

Harvard Business School Research Working Paper No. 11-100

Jegadeesh N, Kim J, Krische SD, Lee C. 2004. Analyzing the analysts: When do recommendations add value? The Journal of Finance 59(3): 1083-1124.

Jensen MC, Meckling WH. 1976. Theory of the firm: managerial behavior, agency costs and ownership structure. Journal of Financial Economics 3(4): 305-360.

Kacperczyk A. 2009. With greater power comes greater responsibility? takeover protection and corporate attention to stakeholders. Strategic Management Journal 30(3): 261-285.

Kandel E, Pearson ND. 1995. Differential interpretation of public signals and trade in speculative markets. Journal of Political Economy: 831-872.

Kapsis RE. 1989. Reputation Building and the Film Art World. The Sociological Quarterly 30(1): 15-35.

Kapstein EB. 2001. The corporate ethics crusade. Foreign Affairs 80(5): 105-119. 289-299.

King A, Lenox M. 2002. Exploring the locus of profitable pollution reduction. Management Science 48(2):

King AA, Lenox MJ. 2001. Does it really pay to be green? An empirical study of firm environmental and financial performance: An empirical study of firm environmental and financial performance. Journal of Industrial Ecology 5(1): 105-116.

Kiron D, Kruschwitz N, Haanaes K, VELKEN IVS. 2012. Sustainability nears a tipping point. MIT Sloan Management Review 53(2): 69-74.

Lang GE, Lang K. 1988. Recognition and renown: The survival of artistic reputation. American Journal of Sociology: 79-109.

Lee DD, Faff RW. 2009. Corporate sustainability performance and idiosyncratic risk: a global perspective. Financial Review 44(2): 213-237.

Lee MDP. 2008. A review of the theories of corporate social responsibility: Its evolutionary path and the road ahead. International journal of management reviews 10(1): 53-73.

Loh RK, Mian GM. 2006. Do accurate earnings forecasts facilitate superior investment recommendations? Journal of Financial Economics 80(2): 455-483.

Lok J. 2010. Institutional logics as identity projects. Academy of Management Journal 53(6): 1305-1335.

Lubin DA, Esty DC. 2010. The sustainability imperative. Harvard Business Review 88(5): 42-50.

MacKenzie D. 2003. Long-Term Capital Management and the sociology of arbitrage. Economy and Society 32(3): 349-380.

Manner MH. 2010. The impact of CEO characteristics on corporate social performance. Journal of Business Ethics 93(1): 53-72.

Marens R, Wicks A. 1999. Getting real: Stakeholder theory, managerial practice, and the general irrelevance of fiduciary duties owed to shareholders. Business Ethics Quarterly: 273-293. 
Margolis JD, Elfenbein HA, Walsh JP. 2007. Does it pay to be good? A meta-analysis and redirection of research on the relationship between corporate social and financial performance. In Working Paper. Ann Arbor.

Margolis JD, Walsh JP. 2003. Misery Loves Companies: Rethinking Social Initiatives by Business. Administrative Science Quarterly 48(2): 268-305.

Mathiasen C, Mell E, Gallimore A. 2012. U.S. Proxy Season Review: Environmental \& Social Issues. Institutional Shareholder Services Inc.

Mattingly JE, Berman SL. 2006. Measurement of corporate social action discovering taxonomy in the Kinder Lydenburg Domini ratings data. Business \& Society 45(1): 20-46.

McWilliams A, Siegel D. 2000. Corporate Social Responsibility and Financial Performance: Correlation or Misspecification? Strategic Management Journal 21(5): 603-609.

Mikhail MB, Walther BR, Willis RH. 1997. Do security analysts improve their performance with experience? Journal of Accounting Research 35: 131-157.

Mikhail MB, Walther BR, Willis RH. 1999. Does forecast accuracy matter to security analysts? The Accounting Review 74(2): 185-200.

Mikhail MB, Walther BR, Willis RH. 2003. The effect of experience on security analyst underreaction. Journal of Accounting and Economics 35(1): 101-116.

Mitchell RK, Agle BR, Wood DJ. 1997. Toward a Theory of Stakeholder Identification and Salience: Defining the Principle of Who and What Really Counts. The Academy of Management Review 22(4): 853-886.

Navarro P. 1988. Why do corporations give to charity? The Journal of Business 61(1): 65-93.

O’Brien P. 1988. Analysts' forecasts as earnings expectations. Journal of Accounting and Economics 10(1): 53-83.

Orlitzky M, Schmidt FL, Rynes SL. 2003. Corporate Social and Financial Performance: A Meta-Analysis. Organization Studies 24(3): 403-441.

Paine LS. 2003. Value shift: Why companies must merge social and financial imperatives to achieve superior performance. McGraw-Hill New York.

Philippe D, Durand R. 2011. The impact of norm-conforming behaviors on firm reputation. Strategic Management Journal 32(9): 969-993.

Phillips DJ, Zuckerman EW. 2001. Middle-Status Conformity: Theoretical Restatement and Empirical Demonstration in Two Markets. American Journal of Sociology 107(2): 379-429.

Podolny JM. 1993. A status-based model of market competition. American Journal of Sociology: 829-872.

Polos L, Hannan MT, Carroll GR. 2002. Foundations of a theory of social forms. Industrial and Corporate Change 11(1): 85-115.

Porter ME, Van der Linde C. 1995. Toward a new conception of the environment-competitiveness relationship. The journal of economic perspectives 9(4): 97-118.

Posner RA. 1990. The problems of jurisprudence. Harvard University Press: Cambridge, MA.

Rao H. 1994. The Social Construction of Reputation: Certification Contests, Legitimation, and the Survival of Organizations in the American Automobile Industry: 1895-1912. Strategic Management Journal 15(S1): $29-44$. $397-418$

Rowley T, Berman S. 2000. A Brand New Brand of Corporate Social Performance. Business Society 39(4):

Ruf B, Muralidhar K, Paul K. 1993. Eight dimensions of corporate social performance: Determination of relative importance using the analytic hierarchy process. Academy of Management Best Paper Proceedings 52: 326330.

Russo MV, Fouts PA. 1997. A resource-based perspective on corporate environmental performance and profitability. Academy of management Journal 40(3): 534-559.

Scharfman M. 1996. The construct validity of the Kinder, Lydenburg and Domini social performance ratings data. Journal of Business Ethics 15(3): 287-296.

Schwartz B. 1987. George Washington: The making of an American symbol. Free Press New York: New York, NY.

Sethi SP. 1975. Dimensions of corporate social performance: an analytical framework for measurement and evaluation. California Management Review 17: 58-64.

Sharfman M. 1996. The construct validity of the Kinder, Lydenberg \& Domini social performance ratings data. Journal of Business Ethics 15(3): 287-296.

Sharma S, Starik M. 2002. Research in corporate sustainability: the evolving theory and practice of organizations in the natural environment. Edward Elgar Publishing.

Sheffrin SM. 1996. Rational expectations. Cambridge University Press: Cambridge, MA. 
Shrum W. 1996. Fringe and fortune: The role of critics in high and popular art. Princeton University Press: Princeton, NJ.

Sinha P, Brown LD, Das S. 1997. A Re-examination of Financial Analysts' Differential Earnings Forecast Accuracy. Contemporary Accounting Research 14(1): 1-42.

Slater DJ, Dixon-Fowler HR. 2009. CEO international assignment experience and corporate social performance. Journal of Business Ethics 89(3): 473-489.

Sparkes R, Cowton CJ. 2004. The maturing of socially responsible investment: a review of the developing link with corporate social responsibility. Journal of Business Ethics 52(1): 45-57.

Steiner GY. 1971. The state of welfare. Brookings Institution Press. 1811-1836.

Stickel SE. 1992. Reputation and performance among security analysts. The Journal of Finance 47(5):

Stickel SE. 1995. The anatomy of the performance of buy and sell recommendations. Financial Analysts Journal 51(5): 25-39.

Strike VM, Gao J, Bansal P. 2006. Being good while being bad: Social responsibility and the international diversification of US firms. Journal of International Business Studies 37(6): 850-862.

Szwajkowski E, Figlewicz RE. 1999. Evaluating corporate performance: a comparison of the Fortune reputation survey and the Socrates social rating database. Journal of Managerial Issues: 137-154.

Thornton PH. 2001. Personal versus market logics of control: A historically contingent theory of the risk of acquisition. Organization Science 12(3): 294-311.

Thornton PH. 2002. The rise of the corporation in a craft industry: Conflict and conformity in institutional logics. Academy of Management Journal: 81-101.

Thornton PH, Ocasio W. 1999. Institutional logics and the historical contingency of power in organizations: Executive succession in the higher education publishing industry, 1958-1990 1. American Journal of Sociology 105(3): 801-843.

Turban DB, Greening DW. 1997. Corporate social performance and organizational attractiveness to prospective employees. The Academy of Management Journal 40(3): 658-672.

Useem M. 1993. Executive defense: Shareholder power and corporate reorganization. Cambridge, Mass.: Harvard University Press.

Useem M. 1996. Investor capitalism: How money managers are changing the face of corporate America. Basic Books: Arizona.

Waddock SA, Graves SB. 1997. The Corporate Social Performance-Financial Performance Link. Strategic Management Journal 18(4): 303-319.

Waldman DA, Siegel DS, Javidan M. 2006. Components of CEO Transformational Leadership and Corporate Social Responsibility. Journal of Management Studies 43(8): 1703-1725.

Westphal JD, Zajac EJ. 1994. Substance and Symbolism in CEOs' Long-Term Incentive Plans. Administrative Science Quarterly 39(3): 367-390.

Westphal JD, Zajac EJ. 1995. Who shall govern? CEO/board power, demographic similarity, and new director selection. Administrative Science Quarterly: 60-83.

Westphal JD, Zajac EJ. 1998. The Symbolic Management of Stockholders: Corporate Governance Reforms and Shareholder Reactions. Administrative Science Quarterly 43(1): 127-153.

Williamson OE, Winter SG. 1993. The nature of the firm: origins, evolution, and development. Oxford University Press.

Womack KL. 1996. Do brokerage analysts' recommendations have investment value? The Journal of Finance 51(1): 137-167.

Zajac EJ, Westphal JD. 2004. The social construction of market value: Institutionalization and learning perspectives on stock market reactions. American Sociological Review 69(3): 433-457.

Zuckerman EW. 1999. The Categorical Imperative: Securities Analysts and the Illegitimacy Discount. The American Journal of Sociology 104(5): 1398-1438. 